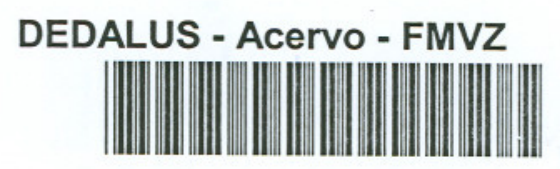

11300025813

\title{
Número total de neurônios no gânglio mesentérico caudal de cães domésticos nas diferentes fases do desenvolvimento. Qual o papel da idade na população total e no tamanho dos neurônios?
}

Dissertação apresentada ao Programa de PósGraduação em Anatomia dos Animais Domésticos e Silvestres da Faculdade de Medicina Veterinária e Zootecnia da Universidade de São Paulo para a obtenção do título de Mestre em Anatomia

Departamento:

Cirurgia

Área de Concentração:

Anatomia dos Animais Domésticos e

Silvestres

Orientador:

Prof. Dr. Antonio Augusto Coppi Maciel Ribeiro

São Paulo 


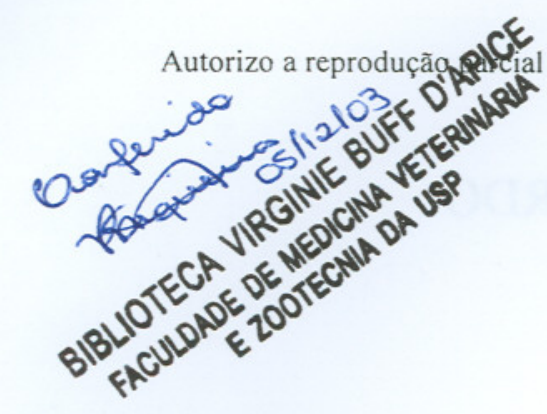

DADOS INTERNACIONAIS DE CATALOGAÇÃO-NA-PUBLICAÇÃO

(Biblioteca da Faculdade de Medicina Veterinária e Zootecnia da Universidade de São Paulo)

T.1338

Gagliardo, Karina Martinez

FMVZ

Número total de neurônios no gânglio mesentérico caudal de cães domésticos nas diferentes fases do desenvolvimento. Qual o papel da idade na população total e no tamanho dos neurônios? / Karina Martinez Gagliardo. - São Paulo : K. M. Gagliardo, 2003.

$111 \mathrm{f}$ : : il.

Dissertação (mestrado) - Universidade de São Paulo. Faculdade de Medicina Veterinária e Zootecnia. Departamento de Cirurgia, 2003.

Programa de Pós-graduação: Anatomia dos Animais Domésticos e Silvestres.

Área de concentração: Anatomia dos Animais Domésticos.

Orientador: Prof. Dr. Antonio Augusto Coppi Maciel Ribeiro.

1. Gânglios. 2. Morfometria. 3. Cães. 4. Envelhecimento. 5. Neurônios. I. Título. I. Título. 


\section{ERRATA}

Página 79

Tabela 2

Tabela 2 - Inter-relação das variáveis peso corpóreo, número total de neurônios, densidade numérica, número de neurônios contados por disector, quantidade de disectors aplicados, volume ganglionar, densidade de volume neuronal e o volume neuronal médio no GMC de cães nos três diferentes grupos etários.

\begin{tabular}{|c|c|c|c|c|c|c|c|c|c|}
\hline GRUPO & Idade & Peso (Kg) & $\begin{array}{c}\text { Densidade } \\
\text { numérica } \\
\left(\begin{array}{c}\text { neurônios/ } \\
\mathbf{m m}^{3} \text { ) }\end{array}\right.\end{array}$ & $\begin{array}{c}\text { Número de } \\
\text { neurônios } \\
\text { contados }\end{array}$ & $\begin{array}{c}\text { Quantidade } \\
\text { de disectors } \\
\text { aplicados }\end{array}$ & $\begin{array}{c}\text { Volume } \\
\text { ganglionar } \\
\left(\mathrm{mm}^{3}\right)\end{array}$ & $\begin{array}{c}\text { Número } \\
\text { total de } \\
\text { neurônios }\end{array}$ & $\begin{array}{c}\text { Densidade } \\
\text { de volume } \\
(\%)\end{array}$ & $\begin{array}{c}\text { Volume } \\
\text { neuronal } \\
\text { médio } \\
\left(\mu \mathrm{m}^{3}\right)\end{array}$ \\
\hline \multirow{3}{*}{$\begin{array}{c}\mathrm{I} \\
\text { (filhotes) }\end{array}$} & 1 meses & 0,15 & $29.142,80$ & 102 & 35 & 2,5 & $73.294,3$ & 32,50 & $11.165,7$ \\
\hline & 2 meses & 0,18 & $28.333,30$ & 102 & 36 & 1,9 & $55.448,3$ & 34,40 & $12.130,6$ \\
\hline & 2 meses & 0,18 & $32.258,10$ & 100 & 31 & 2,5 & $81.677,4$ & 39,00 & $12.093,1$ \\
\hline Média & & 0,17 & $29.911,42$ & & & 2,3 & $70.140,01$ & 35,30 & 11.800 \\
\hline \multirow{3}{*}{$\begin{array}{c}\text { II } \\
\text { (adultos) }\end{array}$} & 1 ano & 18 & 12.500 & 100 & 20 & 89 & 1.112 .500 & 28,40 & 22.720 \\
\hline & 2 anos & 15 & $13.157,80$ & 100 & 19 & 94,5 & 1.243 .421 & 31,80 & $24.183,4$ \\
\hline & 3 anos & 13 & 12.500 & 110 & 22 & 78 & 975.000 & 27,10 & 21.680 \\
\hline Média & & 15,3 & $12.719,27$ & & & 87,2 & $1.110 .307,02$ & 29,10 & $22.866,7$ \\
\hline III & 5 anos & 20 & $10.978,3$ & 104 & 22 & 93,5 & $1.026 .467,40$ & 28,80 & 26.261 \\
\hline (senis) & 10 anos & 17 & $11.818,2$ & 103 & 22 & 96 & $1.134 .545,40$ & 28,90 & $24.487,7$ \\
\hline \multirow{2}{*}{ Média } & 7 anos & 23 & $11.704,55$ & 101 & 23 & 124 & $1.452 .534,10$ & 30,60 & $26.152,2$ \\
\hline & & 20 & $11.500,33$ & & & 104,5 & $1.204 .515,65$ & 29,40 & $25.666,7$ \\
\hline
\end{tabular}




\section{ERRATA}

Página 83

Figura 13D

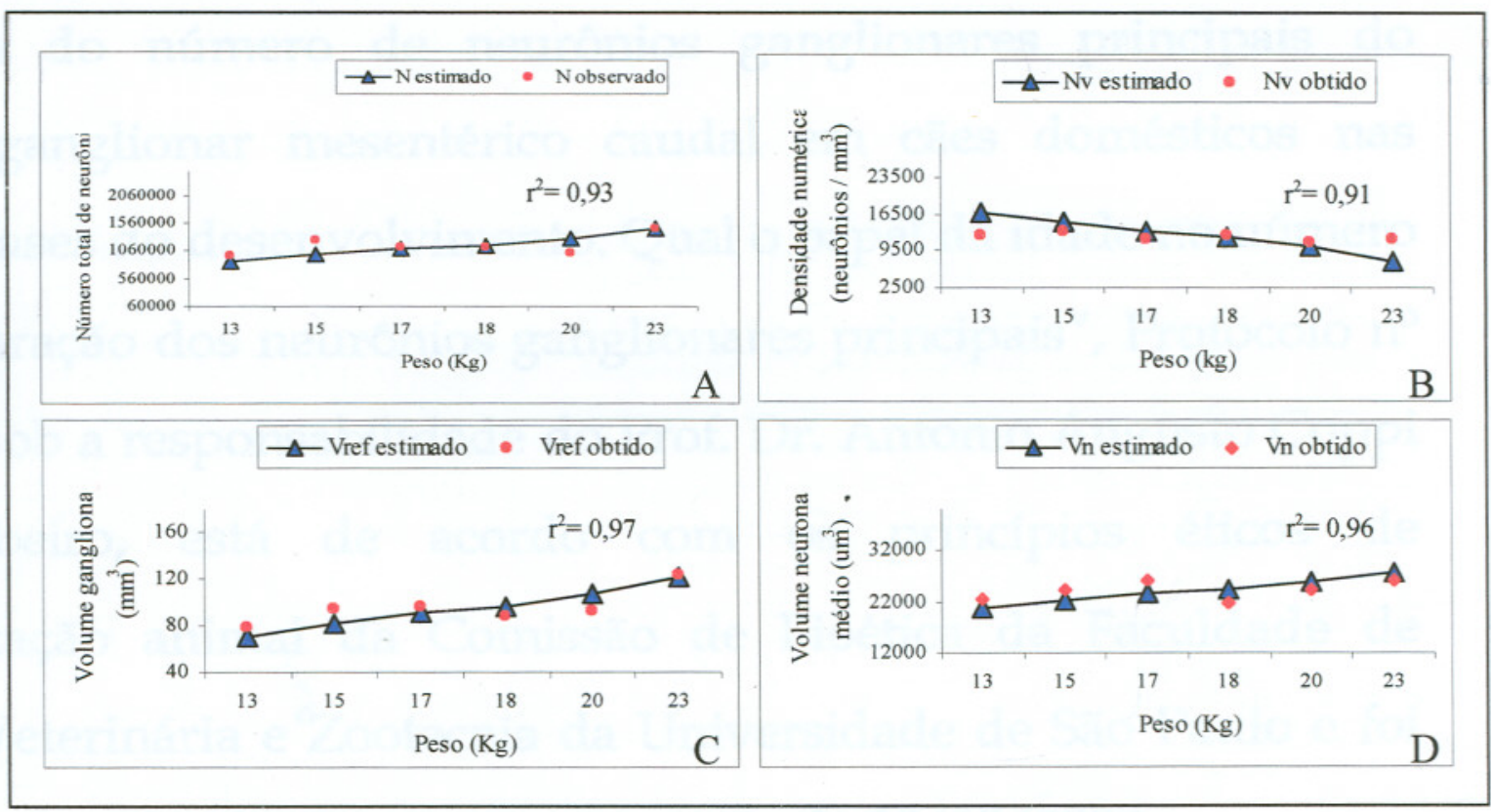

Figura 13 (A-D) - Gráficos demonstrando a relação entre as variáveis estereológicas e o peso corpóreo. A: número total de neurônios e peso corpóreo, B: densidade numérica e peso corpóreo, C: volume ganglionar e peso corpóreo e D: volume neuronal médio e peso corpóreo. 


\section{UNIVERSIDADE DE SÃO PAULO \\ Faculdade de Medicina Veterinária e Zootecnia \\ Cidade Universitaria "Armando de Salles Oliveira" \\ Comissão de Bioética}

\section{CERTIFICADO}

Certificamos que o Projeto intitulado

"Estimativa do número de neurônios ganglionares principais do complexo ganglionar mesentérico caudal em cães domésticos nas liferentes fases do desenvolvimento. Qual o papel da idade no número e na mensuração dos neurônios ganglionares principais", Protocolo ${ }^{\circ}$ 196/2002, sob a responsabilidade do Prof. Dr. Antonio Augusto Coppi aciel Ribeiro, está de acordo com os princípios éticos de experimentação animal da Comissão de Bioética da Faculdade de Medicina Veterinária e Zootecnia da Universidade de São Paulo e foi aprovado pela referida Comissão, em sessão de 30/10/2002.

(We certify that the Research "Estimate of the principal ganglion neurons of the caudal mesenteric ganglion complex in domestic dogs in different stages of development. Can the number and measurement be altered?" protocol number 196/2002, under the responsability of Prof.Dr. Antonio Agusto Coppi Maciel Ribeiro, agree with Ethical Principles in Animal Research adopted by Bioethic Commission of the Faculty of Veterinary Medicine and Zootechny of University of São Paulo and was approved in 10/30/2002 meeting.

São Paulo, 04 de novembro de 2002

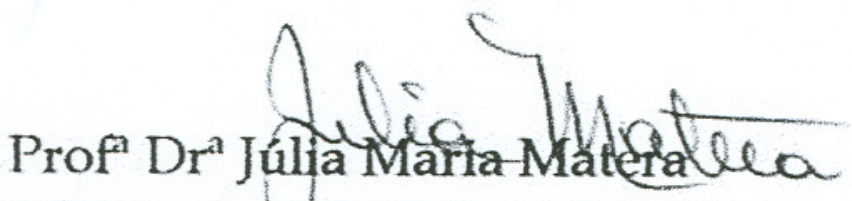

Presidente da Comissão de Bioética 


\section{FOLHA DE AVALIAÇÃo}

Nome do autor: GAGLIARDO, Karina Martinez

Título: Número total de neurônios no gânglio mesentérico caudal de cães domésticos nas diferentes fases do desenvolvimento. Qual o papel da idade na população total e no tamanho dos neurônios?

Dissertação apresentada ao Programa de PósGraduação em Anatomia dos Animais Domésticos e Silvestres da Faculdade de Medicina Veterinária e Zootecnia da Universidade de São Paulo para a obtenção do título de Mestre em Anatomia

Data: $23,12,2003$

Prof. Dr.

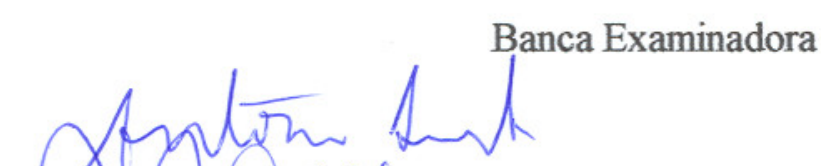

Assinatura:

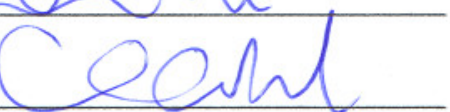

Instituição:

Julgamento:

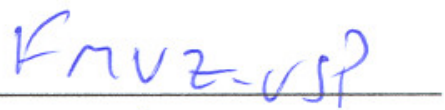
$A \cap R O V A D O$
Instituição: $1 C B-u s P$

Julgamento: APROVADA Instituicão: FIFEOBS / FEEA-USP Julgamento: 
OSenhor é meu pastor; nada me faltará. Deitar-me faz em verdes pastos, guia-me mansamente a águas tranqüilas. Refrigera a minha alma; guia-me pelas veredas da justiça por amor de seu nome. Ainda que eu andasse pelo vale da sombra da morte, não temeria mal algum, porque tu estás comigo; a tua vara e o teu cajado me consolam. Preparas uma mesa perante mim na presença dos meus inimigos, unges a minfia cabeça com óleo, o meu cálice transborda. Certamente que a bondade e a misericórdia me seguirão todos os dias de minha vida; e habitarei na casa do Senfor por longos dias. 
No silêncio do amor, vocês me deram a vida.

Vocês que se doaram e renunciaram seus sonhos para que eu pudesse realizar os meus.

Me ensinaram a viver com dignidade.

Muito mais que meus pais, meus grandes amigos.

Sempre ao meu lado, me fazendo sentir segura e sem medo.

Todo meu amor e admiração

Pelos valores humanos e espirituais que vocês me transmitiram.

..."Nem mesmo o céu , nem as estrelas, nem mesmo o mar e o infinito,

é maior que o amor QUE TENHO POR VOCÊS, nem mais bonito"...

\section{A meu pai, Pedro Acácio Gagliardo}

E a minha mãe, Sandra Regina Martinez Gagliardo

Dedico este trabalho.

Mais do que uma conquista minha

Uma conquista NOSSA. 
Ao meu irmão, Raphael Martinez Gagliardo

Nós, escolhidos por Deus para permanecermos

nossa existência juntos.

Unidos pelo sangue e afeto.

Ligados pela vida.

Obrigada por estar comigo sempre.

Mesmo que longe, sempre perto.

Amo você!

A você, Fábio Linares Silva

Obrigada por ter trilhado junto comigo.

Obrigada por ter feito parte de todas as minhas escolhas e conquistas.

A você dedico tudo de bom que aconteceu em minha vida.

A você o meu afeto, carinho e gratidão. 
À Faculdade de Medicina Veterinária e Zootecnia da Universidade de São Paulo, por ser um dos pilares da minha formação.

À Fundação de Amparo a Pesquisa do Estado de São Paulo - FAPESP, processo $n^{\circ}$. 02/04758-0, pelo apoio financeiro concedido para a realização desta pesquisa.

Ao Prof. Dr. Antonio Augusto Coppi Maciel Ribeiro, meu orientador, pela oportunidade oferecida, orientação, ensinamentos e amizade durante o decorrer desta pesquisa. Obrigada por tudo!

Ao Prof. Dr. Romeu Rodrigues de Souza, pela confiança depositada em mim.

À Profa. Dra. Maria Angélica Miglino, pelo apoio concedido na realização desta dissertação de mestrado.

Ao Prof. Julio Balieiro, pela importante participação na análise dos resultados estatísticos desta dissertação.

Ao Prof. Terry Mayhew, pela orientação nos métodos utilizados nesta dissertação.

Aos Profs. Carlos Alberto Madarim-de-Lacerda e Flávio Paulo de Faria, pelos ensinamentos, muitos dos quais utilizados nesta dissertação.

Aos Profs. Pedro Primo Bombonato, Francisco Javier H. Blasquez, José Roberto Kfoury, Paula Pappa, Irvênia Luiza S. Prada e Wilson Machado de Souza pela amizade, ensinamentos e companheirismo.

Aos meus grandes amigos e técnicos, Edinaldo Ribas Farias ("Índio") e Ronaldo Agostinho da Silva, que acompanharam meus passos desde a minha graduação.

Aos funcionários do Departamento de Cirurgia da FMVZ-USP, área de concentração Anatomia dos Animais Domésticos e Silvestres - Kazue Takiishi, Jaqueline Martins de Santana, Patrícia Aparecida Paixão, Ana Paula Coppi Maciel Ribeiro e Maicon Barbosa da Silva, pela dedicação e companheirismo.

Aos funcionários da Comissão de Pós-graduação da Faculdade de Medicina Veterinária e Zootecnia da Universidade de São Paulo, pela colaboração nos tramites legais para a realização do curso e defesa da dissertação. 
Aos funcionários da Biblioteca da Faculdade de Medicina Veterinária e Zootecnia pelo auxilio na correção desta dissertação.

À Silvia Helena Gerbasi, pela confecção de esquemas desta dissertação.

Aos meus avôs, Othair Scalabrini ("Scala") e Alexandre Gagliardo, por estarem sempre torcendo por mim.

As minhas avós, Neide Guimarães Martinez e Sebastiana Gagliardo, por eu ter a certeza de estarem tomando conta de todos os meus passos e estarem contentes com mais uma conquista minha. Saudades!

Ao meu tio e tia, Ruy Martinez Galarça Junior e Rose Araújo, por terem estado dispostos a me ajudar sempre quando precisei.

À minha GRANDE amiga Naianne Kelly Clebis, pelo apoio, amizade, parceria, companheirismo, confiança e afeto. Não tenho palavras para expressar meus agradecimentos e gratidão por você. Adoro você. Obrigada!

À minha amiga Maria da Glória dos Santos, por sempre me apoiar em todos os meus atos. Mais que uma amiga, um membro de minha família.

À Irena Fateeva (Ira) e Esther Jardim (Nenê), por sempre colocarem meu nome em suas orações e por serem grandes amigas da nossa família.

Aos meus amigos Carlos Eduardo Seifert, Marcelo Domingues de Faria, Lílian de Jesus Oliveira, Lilian Kamikawa, Ana Paula Coppi Maciel Ribeiro, Carlos Eduardo Bezerra de Moura e Hildebrando Gomes Benedicto pela amizade, confiança e companheirismo. Obrigada por fazerem parte de minha estada aqui em São Paulo.

As minhas amiga Ana Paula Vidotti, Patrícia Orlandini Gonçalez, Naianne Kelly Clebis e Dulcineia Teixeira Gonçalves por terem sido minha família em São Paulo. Mais do que dividir uma casa, vocês dividiram comigo o afeto, suas conquistas e sonhos. Fizeram com que a tristeza de estar longe de minha família fosse atenuada pelo carinho de vocês. Muito obrigada!

Aos meus amigos Emerson Ticona Fioretto, Ana Rita de Lima e Wanderley de Lima Guidi, pelo companheirismo. Mais do que um grupo com objetivos comuns, nos tornamos amigos. E que amigos! Obrigada por vocês compartilharem comigo toda a minha trajetória, sempre me apoiando. A vocês, meus agradecimentos. 
Aos meus amigos Danilo Busse Spironelli, Simone Sarkissian, Carolina dos Santos Lopes, Sebastião Pereira de Faria Junior e Priscila Barros Moraes que sempre me incentivaram e apoiaram, mesmo estando longe. Adoro vocês!

A todos meus colegas de pós-graduação, novos e antigos. 


\section{RESUMO}

GAGLIARDO, K. M. Número total de neurônios no gânglio mesentérico caudal de cães domésticos nas diferentes fases do desenvolvimento. Qual o papel da idade na população total e no tamanho dos neurônios? [Total number of neurons in the dog's caudal mesenteric ganglion in different phases of aging. What is the role of aging in the total number and size of neurons?]. 2003. 111f. Dissertação (Mestrado em Anatomia dos Animais Domésticos e Silvestres) - Faculdade de Medicina Veterinária e Zootecnia, Universidade de São Paulo, São Paulo, 2003.

O envelhecimento é caracterizado por um progressivo declínio na função neuronal envolvendo tanto o sistema nervoso central como o periférico. O aumento da idade é verificado por alterações no número e no tamanho dos neurônios. Contudo, estes dados são controversos e pouco conhecidos nos gânglios periféricos. Desta forma, o presente estudo teve como objetivo estudar o gânglio mesentérico caudal (GMC) de cães em dois períodos distintos do desenvolvimento (maturação e envelhecimento) a procura de alterações microestruturais no gânglio e alterações quantitativas e morfométricas nos neurônios presentes neste. A importância do GMC está ligada à inervação simpática do intestino grosso, esfincter anal interno e parcialmente do aparelho urogenital. Para o estudo foram utilizados nove cães domésticos, sem raça definida e machos, divididos em três grupos etários com idades bem definidas (1-2 meses, 1-3 anos e 5-10 anos). Os gânglios foram processados para o estudo da microscopia de luz e as análises morfométrica e estereológica foram, respectivamente, realizadas utilizando o software de análise morfométrica KS 400 ZEISS $^{\circledR}$ e o método estereológico do disector fisico. O aumento da idade foi caracterizado por uma maior quantidade de tecido não neuronal entre os neurônios e um aumento no volume do gânglio. O tamanho dos neurônios do GMC aumenta com a progressão da idade, se encontrando no interior destes a presença de grânulos de lipofucsina. A relação núcleo-citoplasma diminui com a progressão da idade. Quanto às alterações quantitativas, o número total de neurônios no GMC aumenta com a idade em cães adultos e senis, diferentemente da densidade neuronal (neurônios $/ \mathrm{mm}^{3}$ ) que diminui com a progressão da idade. Através do peso corpóreo do cão, foi possível predizer os valores das 
diferentes variáveis estereológicas verificadas neste trabalho, sendo os valores obtidos muito próximos aos reais.

Palavras-chave: Envelhecimento. Neurônios. Gânglio. Morfometria. Cães. 


\begin{abstract}
GAGLIARDO, K. M. Total number of neurons in the dog's caudal mesenteric ganglion in different phases of aging. What is the role of aging in the total number and size of neurons? [Número total de neurônios no gânglio mesentérico caudal de cães domésticos nas diferentes fases do desenvolvimento. Qual o papel da idade na população total e no tamanho dos neurônios?] 2003. 111f. Dissertação (Mestrado em Anatomia dos Animais Domésticos e Silvestres) - Faculdade de Medicina Veterinária e Zootecnia, Universidade de São Paulo, São Paulo, 2003.
\end{abstract}

The aging is characterized by a progressive decline of neuronal function that involves both the central and the peripheral nervous system. Aging process is accompanied by changes in the number and size of neurons. However, these data are controversial and poorly known in the peripheral ganglia. In this way, the present investigation aimed to study the dog's caudal mesenteric ganglion (CMG) in different phases of aging, looking for qualitative, quantitative and morphometric alterations in these neurons. The importance of the CMG is associated with the innervation of the lower large intestine, internal anal sphincter and partially the urogenital system. To the study, was used nine males, mongrel, domestic dogs from the Veterinary Hospital of the Veterinary and Zoöthecny College of the São Paulo University. They were divided into three different well defined aged groups (1-2 months old; 1-3 years old; 5-10 years old). The ganglia were processed for the light microscopy study. The morphometric and stereological analyses were, respectively, done using morphometric analyses software KS 400 Zeiss ${ }^{\circledR}$ and the stereological physical disector method. The increase of age was caractherized by a major amount of the non-neuronal tissue between the neurons and a increase of ganglion volume. The size of the neurons, represented by their sectional area, also increased with the age, being frequent, the presence of lipofucsin granules in old animals. The nucleus-citoplasmic relation of neurons of the CMG tend to decrease with the age. Referring to the quantitative changes, the total number of neurons in the CMG increased by aging in adults and elder dogs, differently of the neuronal density (neurons/mm3) which decreased with the aging. Through the body weight of the dog, it 
was possible to predict the values of the different stereological variables represented in this paper, where, the obtained values were close to the normal rates.

Key words: Aging. Neurons. Ganglia. Morphometric. Dogs 


\section{LISTA DE ILUSTRAÇÕES}

Figura 1 (A-B) - Quantificação do número de "transects" (ou Q") no disector

Figura 2 (A-B) - Fotomicrografias utilizadas para quantificação do número de "transects" (ou Q")

Figura 3 - Estimativa do volume pelo método de Cavalieri

Figura 4 - Estimativa da densidade de volume neuronal

Figura 5 (A-B) - Macroestrutura do gânglio mesentérico caudal de cães e suas conexões (vista caudal)

Figura 6 - Massas ganglionares (ou lobos ganglionares) encontrados nos filhotes

Figura 7 (A-C) - Microestrutura do gânglio mesentérico caudal

Figura 8 (A-C) - Microestrutura dos três diferentes grupos etários

Figura 9 - Distribuição das classes das áreas seccionais dos neurônios do GMC nos três diferentes grupos etários

Figura 10 - Distribuição das classes das áreas seccionais dos núcleos do GMC nos três diferentes grupos etários

Figura 11 - Distribuição das classes da relação entre núcleo-citoplasma nos três diferentes grupos etários

Figura 12 - Distribuição das classes de "Form Factor" nos três diferentes grupos etários

Figura 13 (A-D) - Gráficos demonstrando a relação entre as variáveis estereológicas e o peso corpóreo

Figura 14 - Relação entre a densidade de volume e o peso corpóreo 


\section{LISTA DE TABELAS}

Tabela 1 - Médias das variáveis morfométricas nos três diferentes grupos etários.

Tabela 2 - Inter-relação das variáveis peso corpóreo, número total de neurônios, densidade numérica, número de neurônios contados por disector, quantidade de disectors aplicados, volume ganglionar, densidade de volume neuronal e o volume neuronal médio no GMC de cães nos três diferentes grupos etários.

Tabela 3 - Média das variáveis estereológicas nos três diferentes grupos etários. 


\section{SUMÁRIO}

1 INTRODUÇÃO

2 REVISÃO DA LITERATURA 22

2.1 SISTEMA NERVOSO AUTÔNOMO 22

2.2 ANATOMIA MACROSCÓPICA: GÂNGLIO MESENTÉRICO CAUDAL 27

2.3 ASPECTOS MORFOFUNCIONAIS: GÂNGLIO MESENTÉRICO CAUDAL 29

2.4 ANATOMIA MICROSCÓPICA: GÂNGLIOS PRÉ-VERTEBRAIS 30

2.5 EFEITO DO ENVELHECIMENTO NOS NEURÔNIOS 35

3 MATERIAL E MÉTODOS 43

3.1 MATERIAL $\quad 44$

3.2 MÉTODOS $\quad 45$

3.2.1 Estudo histológico $\quad 45$

3.2.1.1 Lavagem do sistema circulatório e fixação do gânglio por meio de perfusão $\quad 45$

3.2.1.2 Processamento do material 46

$\begin{array}{ll}\text { 3.2.1.3 Microscopia de luz de cortes semi-finos } & 47\end{array}$

$\begin{array}{ll}\text { 3.2.2 Estudo morfométrico } & 47\end{array}$

3.2.3 Estudo estereológico $\quad 49$

3.2.3.1 Quantificação neuronal (método do disector fisico associado ao volume $\quad 49$ referência)

3.2.3.2 Densidade numérica ou densidade neuronal (Nv) 54

3.2.3.3 Volume do espaço referência ou ganglionar (Vref) 56

3.2.3.3.1 Método de Scherle $\quad 56$

3.2.3.3.2 Método de Cavalieri $\quad 57$

3.2.3.3.2.1 Cálculo da área seccional $\quad 60$

3.2.3.4 Estimativa do número total de neurônios $\quad 60$

3.2.3.5 Estimativa da densidade de volume (Vv) 61

3.2.3.6 Estimativa indireta do volume neuronal médio $(\mathrm{Vn})$

3.2.4 Analise estatística $\quad 62$

4 RESULTADOS 64

4.1 ANATOMIA MACROSCÓPICA DO GMC 65

4.2 ANATOMIA MICROSCOPICA DO GMC 66

4.3 ESTUDO MORFOMÉTRICO $\quad 71$

$\begin{array}{ll}\text { 4.3.1 Análise estatística } & 74\end{array}$ 
4.3.1.1 Análise de variância (ANOVA)

4.3.1.2 Análise de correlação $\quad 76$

4.4 ESTUDO ESTEREOLÓGICOS

4.4.1 Análise estatística $\quad 80$

4.4.1.1 Análise de variância (ANOVA) 80

4.4.1.2 Análise de correlação $\quad 81$

4.4.1.3 Análise de regressão linear $\quad 82$

5 DISCUSSÃO

5.1 ASPECTOS TÉCNICOS 85

5.2 ASPECTOS MORFOLÓGICOS: MACRO E MICROESTRUTURAIS 89

5.3 ASPECTOS MACRO E MICROMORFOMÉTRICOS 90

5.3 ASPECTOS ESTEREOLÓGICOS 92

5.3.1 Volume do espaço referência ou ganglionar (Vref) 92

5.3.2 Densidade numérica ou neuronal (Nv) 92

5.3.3 Número total de neurônios 93

5.3.4 Relação entre as variáveis estereológicas e o peso corpóreo 95

6 CONCLUSÃO 98

$\begin{array}{ll}\text { REFERENCIAS } & 101\end{array}$ 


\section{INTRODUÇ̃̃O}

O envelhecimento, como parte do processo de desenvolvimento, é um evento esperado e normal em todas as espécies animais. Nos mamíferos, a senescência está associada a alterações nas funções fisiológicas e a uma maior suscetibilidade ao aparecimento de doenças degenerativas. Está claro que os prejuízos celulares e fisiológicos que ocorrem com a progressão da idade são resultados de uma interação de vários fatores, podendo dizer que a idade é um fenômeno multifacetado (SZWEDA et al., 2003).

No sistema nervoso, a progressão da idade é verificada por um declínio funcional que envolve tanto o sistema nervoso central como o periférico. As alterações freqüentemente relacionadas são a perda e a atrofia neuronal, embora tal afirmação é discutível, pois são verificadas diferenças entre as diversas regiões do sistema nervoso e entre as espécies (FINCH, 1993; VEGA; CALZADA; DEL VALLE, 1993).

Os efeitos da idade nos gânglios simpáticos pré-vertebrais são pouco conhecidos, embora nos últimos 20 anos estes gânglios têm sido estudados exaustivamente com o auxílio de técnicas farmacológicas, eletrofisiológicas, imuno-histoquímicas e bioquímicas (MIOLAN; NIEL, 1996); sendo considerados os melhores modelos para estudar e possivelmente solucionar problemas pertinentes ao trato gastrointestinal (GONELLA; BOUVIER; BLANQUET, 1987), uma vez que controlam importantes funções como secreção e absorção de substâncias na parede intestinal, fluxo sanguíneo, participam em arcos reflexos (SZURSZEWSKY; KING, 1988), mesmo com a descentralização do gânglio (BYWATER, 1993; GONELLA; BOUVIER; BLANQUET, 1987; LUCKENSMEYER; KEST, 1995, 1996). 
Embora o avanço científico acerca destes gânglios tenha se concentrado nestes últimos anos, são encontradas descrições sobre os mesmos pouco antes do início do século II d.C. Galeno (129-199 d.C.), médico grego de grande importância na antiguidade, já havia identificado elementos nervosos extrínsecos que se dirigiam ao trato gastrointestinal e concluído que estes possivelmente exerciam influências sobre as vísceras abdominais. Estes elementos, isto é, o agrupamento de gânglios encontrado ao longo da aorta abdominal, foram posteriormente denominados por Gaskell em 1886 de gânglios pré-vertebrais, definição esta que persiste até os dias atuais (SZURSZEWSKI; KING, 1988).

Os gânglios pré-vertebrais integram o sistema nervoso simpático, juntamente com os gânglios paravertebrais e alguns paraviscerais. A diferença entre eles é que os paravertebrais formam duas cadeias simpáticas de ambos os lados da coluna vertebral e estão conectados à medula espinhal toracolombar via ramos comunicantes brancos, e os pré-vertebrais estão, em sua maioria, participando da constituição de plexos intimamente relacionados à aorta abdominal. Além destas, uma importante diferença entre eles é que os neurônios ganglionares pré-vertebrais não recebem impulso somente da medula, mas também de neurônios localizados na parede dos intestinos e de neurônios localizados em gânglios adjacentes aos plexos abdominais (ELFVIN; LINDH; HÖKFELT, 1993; GABELLA, 1995).

Nos gânglios simpáticos não são encontradas alterações celulares degenerativas significantes com o envelhecimento, havendo apenas um aumento no depósito de pigmentos como lipofucsina e neuromelanina no interior dos neurônios (SCHMITH, 1993a, 1996). As alterações na arborização dendrítica e axonal, freqüentemente correlacionadas com a senilidade, não são provocadas por efeitos diretos da mesma, e sim secundárias às mudanças que ocorrem nos órgãos alvos (ANDREWS, 1996), pois com a progressão da idade pode ocorrer diminuição ou aumento de alguns fatores neutróficos liberados por estes órgãos (BENNETT; GIBSON; LEMON, 2003; CRUTCHER, 2002; GAVAZZI; COWEN, 1996). 
A perda neuronal foi durante muito tempo um pré-requisito para se compreender os efeitos do envelhecimento no sistema nervoso (WEST, 1994). Inúmeros trabalhos em meados da década de 50 relataram uma diminuição na densidade neuronal por área ("packing density") com a progressão da idade no cérebro, erroneamente descrevendo que o número total de neurônios diminuía. Com o desenvolvimento de procedimentos acurados e imparciais para contagem de neurônios, esta afirmação se modificou nos últimos anos, particularmente com o advento das ferramentas estereológicas para a estimação do número total de partículas. Com isso, concluiu-se que o declínio no número de neurônios através da morte celular não está significativamente correlacionado com o envelhecimento (MORRISON; HOF, 1997).

Devido à falta de dados quantitativos e morfométricos sobre os componentes celulares dos gânglios simpáticos nas diferentes etapas do desenvolvimento em grandes mamíferos, e ainda a grande importância funcional do gânglio mesentérico caudal (GMC) na inervação do trato gastrointestinal (inervação simpática do cólon e esfíncter anal interno) e parcialmente do aparelho urogenital, este estudo teve por objetivo investigar possíveis alterações microestruturais, quantitativas e morfométricas do GMC com ênfase nos seus neurônios ganglionares em dois períodos distintos do desenvolvimento: maturação e envelhecimento.

A espécie canina foi escolhida pelo fato de representar um modelo experimental de fácil acesso cujos aspectos de sua biologia são claramente conhecidos. Ainda, partimos de observações preliminares nesta espécie (GAGLIARDO et al., 2003), porém agora acrescentando uma visão quantitativa durante o desenvolvimento. Os resultados obtidos com esta investigação podem ser úteis no entendimento e tratamento de algumas enteropatias associadas ou não ao envelhecimento. 
REVISÃO DA LITERATURA 


\section{REVISÃO DA LITERATURA}

A literatura relacionada ao sistema nervoso autônomo é vasta, no entanto poucos trabalhos enfocam os gânglios simpáticos pré-vertebrais, principalmente em grandes mamíferos. Ainda, as alterações do desenvolvimento são diferentes entre os diversos gânglios e pouco conhecidas. Tendo em vista estes problemas, este capítulo tem como objetivo descrever de forma didática o sistema nervoso autônomo, a anatomia macroscópica e os aspectos morfofuncionais do gânglio mesentérico caudal (GMC), a anatomia microscópica dos gânglios pré-vertebrais e os efeitos do desenvolvimento (maturação e envelhecimento) nos neurônios.

\subsection{SISTEMA NERVOSO AUTÔNOMO}

O sistema nervoso autônomo (SNA), também denominado de sistema nervoso visceral ou vegetativo, é representado pelo componente eferente (motor) do sistema nervoso visceral (DÂNGELO; FATTINI, 1987; DI DIO; NITRINE, 2002; MACHADO, 2002; RANSON, 1955) e relaciona-se com a inervação das estruturas viscerais, sendo responsável pela manutenção da constância do meio interno, isto é, a homeostase (BRODAL,1984; DANGELO; FATTINI, 1987; HASSER; SCHADT, 1990; JUNQUEIRA; CARNEIRO, 1995; POWLEY, 1999).

Embora a classificação de SNA restrinja-se apenas ao componente eferente visceral, há muitas dúvidas sobre esta classificação, pois alguns referem que as fibras aferentes viscerais devem ser consideradas aferentes autonômicas, devido à mesma origem embriológica, por caminharem junto 
com o mesmo nervo periférico que contém a fibra autonômica eferente e por participarem de arcos reflexos com as vísceras (POWLEY, 1999).

Diferente da inervação motora somática da musculatura estriada esquelética, a inervação eferente das vísceras se processa através de dois neurônios, um pré e um pós-ganglionar. O primeiro referido é considerado um neurônio excitatório, apresentando o corpo celular dentro do sistema nervoso central, já o outro, o pós-ganglionar, apresenta o corpo celular em gânglios, e o neurônio pode ser excitatório ou inibitório (BRODAL, 1984; GONELLA; BOUVIER; BLANQUET, 1987; RANSON, 1955).

O termo autônomo deriva do grego e significa "auto-governo" ou "independente". Ainda que o significado desta terminologia possa dar uma impressão de que esta parte do sistema nervoso funcione de modo completamente independente, as funções do SNA sofrem constantemente influência da atividade consciente do sistema nervoso central (HASSER; SCHADT, 1990; JUNQUEIRA; CARNEIRO, 1995; RANSON, 1955).

O SNA foi dividido primariamente em dois componentes: simpático e o parassimpático. Esta divisão foi feita por Langley em 1898, devido às diferenças farmacológicas encontradas entre estes dois componentes (POWLEY, 1999), sendo encontrado como neurotransmissor principal entre a fibra pré e pós-ganglionar, tanto no sistema nervoso simpático como parassimpático, a acetilcolina. Já para as fibras pósganglionares simpáticas o neurotransmissor clássico é a norepinefrina, enquanto que para as parassimpáticas a neurotransmissor é acetilcolina (ELFVIN; LINDH; HÖKFELT, 1993; HASSER; SCHADT, 1990). Uma terceira divisão do SNA, recentemente considerada, mas já preconizada por Langley, é o sistema nervoso entérico. Este é encontrado em toda parede do trato gastrointestinal, apresentando uma organização muito mais complexa do que dos gânglios simpáticos e parassimpáticos (MACHADO, 2002), contendo neurônios intrínsecos 
aferentes, interneuronios e neurônios intrínsecos eferentes que controlam a função local independente do controle extrínseco (POWLEY, 1999; SMOLEN, 1988).

Os gânglios autônomos são organizados em grupos e podem ser subdivididos sistematicamente em: gânglio paravertebral, pré-vertebral, paravisceral e intramural. Estes gânglios, acrescentados dos troncos nervosos, constituem os plexos viscerais (ELFVIN; LINDH; HÖKFELT, 1993; GABELLA, 1995; MIOLAN; NIEL, 1996) os quais não são puramente simpáticos ou parassimpáticos, mas contêm elementos dos dois sistemas, além de fibras viscerais aferentes (MACHADO, 2002). Os gânglios são vistos como grandes massas ou protusões ao longo dos troncos nervosos ou como nódulos no centro da malha dos nervos (GABELLA, 1995).

Os dois primeiros gânglios supracitados são considerados simpáticos, apresentando a mesma origem embriológica, isto é, derivam da migração das células da crista neural (LARSEN, 1997) da região torácica. Estas dão origem a neuroblastos que formam os gânglios espinhais, mas alguns neuroblastos seguem migrando ventrolateralmete para formar os gânglios simpáticos paravertebrais de disposição segmentar. Ainda, alguns neuroblastos simpáticos migram para diante da aorta e formam os gânglios pré-vertebrais (LANGMAN, 1985).

Os neurônios encontrados nos gânglios simpáticos paravertebrais apresentam ao menos três diferentes tipos de neurotransmissores: norepinefrina, norepinefrina mais neuropeptídeo Y e acetilcolina mais polipeptídeo intestinal vasoativo (VIP). O primeiro tipo é responsável pela inervação do parênquima dos órgãos-alvos, o segundo pela inervação dos vasos sanguíneos e o terceiro pela inervação das glândulas. Nos gânglios pré-vertebrais, além dos neurotransmissores anteriormente referidos, é encontrada a norepinefrina mais 
somatostatina, responsável pela inervação dos intestinos (SMOLEN, 1988) e também substância P e encefalina (GABELLA, 1995).

Os corpos celulares dos neurônios pré-ganglionares simpáticos estão localizados na coluna intermediolateral da medula espinhal toracolombar, tendo os axônios dirigindo para os gânglios simpáticos paravertebrais ou pré-vertebrais. Os gânglios simpáticos paravertebrais estão localizados em ambos os lados da coluna vertebral, formando duas cadeias simpáticas, já os pré-vertebrais são encontrados ventrais (anterior) ou ventro-laterais (antero-lateral) da aorta abdominal. As fibras espinhais pré-ganglionares chegam aos gânglios paravertebrais via ramo comunicante branco (mielínico) e as fibras pós-ganglionares deixam o gânglio através do ramo comunicante cinzento (amielinico) para se ligarem ao nervo espinhal e seguir para o órgão efetor. As fibras pré-ganglionares podem também fazer sinapse em um gânglio prévertebral, onde chegam através dos ramos esplâncnicos que, assim, poderiam ser considerados como ramos comunicantes branco, mas muito longos (ELFVIN; LINDH; HÖKFELT, 1993; MACHADO,2002).

Os gânglios simpáticos para e pré-vertebrais são similares estruturalmente. A diferença estabelecida entre eles é que os neurônios ganglionares pré-vertebrais não recebem impulsos somente da medula através dos nervos esplâncnicos, mas também de neurônios localizados na parede dos intestinos e de neurônios localizados em gânglios adjacentes aos plexos abdominais (ELFVIN; LINDH; HÖKFELT, 1993; GABELLA, 1995). Os impulsos provenientes dos neurônios do plexo entérico contêm VIP, bombesin e colecistoquinina (SMOLEN, 1988).

Devido à natureza dos neuromediadores (clássicos ou novos) e os mecanismos de neurotransmissão e de neuromodulação presentes nos gânglios pré-vertebrais, estes gânglios 
são considerados como "pequenos cérebros", pois todos os elementos são muito similares àqueles existentes no sistema nervoso central (MIOLAN; NIEL, 1996).

Os gânglios simpáticos pré-vertebrais são constituídos pelo gânglio celiaco, mesentérico cranial (superior) e o mesentérico caudal (inferior). Estes contêm corpos celulares de neurônios simpáticos pós-ganglionares responsáveis pela inervação dos órgãos do trato gastrointestinal e urogenital. O posicionamento destes gânglios é similar nas diferentes espécies, mas existe considerável variabilidade na anatomia entre a mesma espécie e em espécies diferentes (SZURSZEWSKI; KING, 1988; SZURSZEWSKI; MILLER, 1994).

\subsection{ANATOMIA MACROSCÓPICA: GÂNGLIO MESENTÉRICO CAUDAL}

O gânglio mesentérico caudal (GMC), responsável pela inervação do intestino grosso, do esfincter anal interno e parcialmente o aparelho urogenital (MIOLAN; NIEL, 1996), apresenta um formato alongado em cães e está situado ventralmente à aorta abdominal, ao redor da origem da artéria mesentérica caudal, que é um ramo ímpar da aorta situada caudalmente aos rins e que supre as partes média e caudal do cólon descendente e a parte cranial do reto (EVANS, 1993; GAGLIARDO et al., 2003; GHOSHAL, 1986).

A porção cranial do GMC é atingida por nervos esplâncnicos lombares que são responsáveis por trazerem ao gânglio a inervação simpática. Estes são provenientes dos gânglios lombares ou dos ramos interganglionares do tronco simpático abdominal (EVANS, 1993). No cão, os nervos esplâncnicos que se destinam ao GMC apresentam freqüentemente origem nos ramos interganglionares de L4-L5 (GAGLIARDO et al, 2003). O quinto nervo esplâncnico lombar vai 
diretamente para o GMC de cães, no entanto, o sexto e o sétimo nervos esplâncnicos lombares estão variavelmente presentes e podem se estender até o gânglio (GHOSHAL, 1986; MIZERES,1955).

Além dos nervos esplâncnicos lombares, o GMC também é conectado cranialmente com os nervos intermesentéricos. Estes nervos são responsáveis por conectar o gânglio celíaco-mesentérico ao mesentérico caudal ou inferior (GABELLA, 1995; GAGLIARDO et al., 2003; MIOLAN; NIEL, 1996; MIZERES, 1955; SCHWARZE; SCHRÖDER, 1970).

Caudalmente, a continuação do GMC dá-se pelos nervos hipogástricos direito e esquerdo, bilateralmente simétricos. Estes adentram a cavidade pélvica abaixo do peritônio, formando o plexo pélvico, juntamente com os nervos pélvicos parassimpáticos (GABELLA, 1995; GHOSHAL, 1986; MIZERES, 1955; SZURSZEWSKI; MILLER, 1994).

Além dos nervos hipogástricos direito e esquerdo, um terceiro tronco nervoso deixa o GMC. Este tronco nervoso, denominado de nervo hipogástrico principal (GABELLA, 1995; GAGLIARDO et al., 2003) ou de nervo colônico lombar (EVANS, 1993; GHOSHAL, 1986), acompanha a artéria mesentérica inferior (caudal) em todo seu trajeto (EVANS, 1993; GABELLA, 1995; GHOSHAL, 1986). Este nervo se divide em dois troncos, juntamente com a artéria mesentérica caudal. Um tronco segue cranialmente, junto com a artéria colônica esquerda, e outro caudalmente, juntamente com a artéria retal cranial, recebendo estes os mesmos nomes das respectivas artérias. A partir destes dois troncos, as fibras nervosas que se dirigem ao cólon e ao reto, são denominandas, respectivamente, de nervos colônicos e retais (GAGLIARDO et al., 2003). Os troncos anteriormente referidos são responsáveis pela formação dos plexos cólico esquerdo e hemorroidal cranial (SCHWARZE; SCHRÖDER, 1970). 


\subsection{ASPECTOS MORFOFUNCIONAIS: GÂNGLIO MESENTÉRICO CAUDAL}

Os gânglios pré-vertebrais são responsáveis pela modulação do sistema nervoso entérico, onde causam vasoconstrição, diminuição na secreção luminal e inibição da motilidade da musculatura lisa (LUCKENSMEYER; KEST, 1995). A inibição da motilidade ocorre pelo fato dos neurônios pós-ganglionares liberarem norepinefrina, na qual bloqueia a transmissão sinaptica nos gânglios do sistema nervoso entérico e também, provavelmente, hiperpolariza as células musculares lisas (GONELLA; BOUVIER; BLANQUET, 1987).

O plexo mioentérico, componente do sistema nervoso entérico, apresenta neurônios viscerofugais (neurônios sensoriais) que se dirigem aos gânglios pré-vertebrais. Estes neurônios são excitados com a distensão das alças e em alguns casos com a irritação química ou mecânica da mucosa. O aumento do fluxo de saída destes impulsos causa inibição de determinada região do trato gastrointestinal. Estes reflexos agem independentemente do controle do sistema nervoso central, pois eles operam mesmo com a descentralização dos gânglios pré-vertebrais (BYWATER, 1993; LUCKENSMEYER; KEST, 1995, 1996).

O GMC é um importante centro integratório da inervação do intestino grosso. Os neurônios viscerofugais chegam no GMC através do nervo colônico lombar (hipogástrico principal), nervos hipogástricos direito e esquerdo e intermesénterico (FUKUDA; FUKAI; OKADA, 1987; LUCKENSMEYER; KEAST, 1995, 1996; MING-ZI LI; MASUKO, 1997). Os neurônios viscerofugais que projetam para o gânglio mesentérico inferior via nervo colônico lombar e hipogástricos são poucos encontrados na terminação rostral do cólon proximal, mas estes aumentam no sentido caudal, encontrando o número máximo de neurônios no reto (LUCKENSMEYER; KEST, 1995). 
A ressecção do GMC altera todo o peristaltismo normal da porção média e distal do cólon, levando a freqüentes movimentos das alças, ocasionando a diarréia. Estas observações são freqüentemente constatadas em pacientes com câncer nos intestinos, onde uma extensiva dissecção dos linfonodos regionais é exigida, necessitando muitas vezes a remoção dos nervos autônomos encontrados ao redor da artéria mesénterica caudal (IRIE et al., 1998).

A inervação simpática para os órgãos pélvicos é proveniente dos nervos hipogástricos direito e esquerdo que deixam o GMC (DYCE; SACK; WENSING, 1997). No trato reprodutivo da fềmea, em algumas espécies, como na porca, a principal contribuição simpática é proveniente do GMC, onde se encontra a maior população de neurônios responsáveis por inervar o útero (WASOWICK; MAJEWSKI; LAKOMY, 1998) e também neurônios responsáveis por inervar a musculatura lisa da genitália. Na cadela, são verificados no GMC neurônios responsáveis por inervar o ovário (CHIHSIEN CHIEN; SHIH-HSIUNG LI; CHING-LIANG SHEN, 1991).

No trato reprodutivo do macho, a contribuição simpática proveniente do GMC é de grande importância. Os nervos hipogástricos (direito e esquerdo) são responsáveis pelas funções primárias da ejaculação, como a contração do vaso deferente (KIHARA et al, 1998; KIHARA; SATO; OSHIMA, 1998). A ablação do gânglio mesentérico inferior resulta em um aumento de espermatozóides no vaso deferente (BILLUPS; TLLMAN; CHANG, 1990a) e conseqüentemente em mudanças na velocidade do espermatozóide (BILLUPS; TILLMAN; CHANG, 1990b). Recentemente, foi verificado que a função do nervo hipogástrico pode ser preservada mesmo depois do nervo ser seccionado cirúrgicamente (KIHARA; SATO; OSHIMA, 1998). Ainda, o nervo hipogástrico do cão pode ser reconstruído espontaneamente ( KOBAYASHI et al., 2001).

A inervação simpática não apresenta nenhum efeito na micção. No entanto, os nervos de origem simpática são responsáveis por contrair o colo da bexiga durante a ejaculação (KIHARA; GROAT, 1997; SWENSON; REECE, 1996). No GMC de gatos e "guinea pig" foi encontrado 
populações heterogêneas de neurônios responsáveis pela inervação da bexiga urinária (NOZDRACHEV et al. 1988), embora seja relatado que a inervação simpática é proveniente dos nervos esplâncnicos lombares com origem na porção de L2-L6, onde estes podem cruzar o GMC e, através dos nervos hipogástricos, caminham para o plexo pélvico (KIHARA; GROAT, 1997; KIHARA et al., 1998).

\subsection{ANATOMIA MICROSCÓPICA: GÂNGLIOS PRÉ-VERTEBRAIS}

Um gânglio é definido como um aglomerado de corpos celulares localizados fora do sistema nervoso central. Os gânglios pré-vertebrais encontram-se envolvidos por uma cápsula de tecido conjuntivo, vascularizada, cujo finas fibras reticulares e colágenas enviam septos para o interior destes, dividindo-o em compartimentos (BANKS, 1992; GABELLA; TRIGG; MCPHAIL, 1988; GAGLIARDO et al., 2003; MIOLAN; NIEL, 1996; SCHMIDT, 1996; SZURSZEWSKI; KING, 1988; SZURSZEWSKI; MILLER, 1994). A cápsula ao redor do gânglio forma uma barreira similar ao perineuro dos nervos periféricos, prevenindo a passagem de proteínas para o espaço extracelular do gânglio (SZURSZEWSKI; KING, 1988; SZURSZEWSKI; MILLER, 1994).

O arranjo dos neurônios ganglionares em compartimentos ("clusters") ocorre em gânglios responsáveis pela inervação de um vasto número de órgãos efetores com diferentes funções (BHAMBURKAR; PRAKASH, 1993). Nos grandes mamíferos, como o homem, o cão, o gato, o coelho e o porco, os neurônios tendem a formar "clusters" (GAGLIARDO et al., 2003; KALECZYC et al., 1995; PIDSUKO et al., 2001; RIBEIRO et al., 2002; SASAHARA et al., 2003; SCHMITH; DORSEY; ROTH, 1992), diferentemente dos pequenos mamíferos, como os guinea pigs e ratos, onde estes não são especificamente arranjados em uma particular região do gânglio (PIDSUDKO et al., 2001). 
Os gânglios pré-vertebrais são constituídos principalmente por três tipos celulares: o neurônio ganglionar, a célula da glia e a célula SIF (small intensely fluorescent cell), também conhecida como célula de cromaffin, interneuronios ou pequenos neurônios (GABELLA, 1995; GAGLIARDO et al., 2003; MIOLAN; NIEL, 1996; SZURSZEWSKI; KING, 1988; SZURSZEWSKI; MILLER, 1994).

Os gânglios mesentérico caudal de cão e celíaco mesentérico de cão e de coelho são formados por um aglomerado de unidades ganglionares, onde os principais componentes são os neurônios, células da glia e as células SIF, separadas por fibras nervosas, capilares intraganglionares (inter-unidades) e septos de fibras colágenas do tipo I e III, envoltos por uma cápsula composta por fibras colágenas do tipo I e fibras elásticas. Os septos constituídos de fibras colágenas apresentam fibroblastos e capilares (GAGLIARDO et al., 2003; RIBEIRO et al., 2002; SASAHARA et al., 2003).

Os neurônios ganglionares são facilmente visualizados devido ao seu grande tamanho e ao proeminente nucléolo encontrado em seu núcleo pálido (MILLER et al., 1996). Nos gânglios simpáticos eles geralmente são multipolares (BRODAL, 1984; COMARCK, 1987; GABELLA, 1995; SZURSZEWSKI; MILLER, 1994; WHEATER; BURKITT; DANIELS, 1994) e caracterizados por dendritos longos e numerosos. Os dendritos podem ramificar-se abundantemente dentro da cápsula ou podem penetrá-la. Devido aos numerosos e longos dendritos, é freqüentemente dificil identificar os processos celulares que possam ser designados como axônios (BRODAL, 1994; ERMILOV et al., 2000; SZURSZEWSKI; MILLER, 1994).

Os neurônios simpáticos exibem uma considerável variação na morfologia dos dendritos, demonstrando nos gânglios cervical superior e celíaco uma irradiação dos dendritos paralela com o plano frontal destes gânglios, e no gânglio torácico uma irradiação no plano 
obliquo do gânglio (JOBLING; GIBBINS, 1999). Ainda, os neurônios no gânglio mesentérico inferior de ratos são encontrados em diferentes camadas, fazendo com que a arborização dendrítica entre estas diferentes camadas de neurônios não se misture, não demonstrando extensivas conexões sinapticas neste gânglio (ERMILOV et al., 2000). A complexidade da arborização dendrítica é maior de acordo com o maior tamanho da espécie animal (PURVES et al., 1986).

Apenas um núcleo é encontrado no interior dos neurônios dos gânglios pré-vertebrais (MIOLAN; NIEL, 1996), com exceção de algumas espécies como o guinea pig (ERMILOV et al., 2000; SZURSZEWSKI; MILLER, 1994), capivara (RIBEIRO, 2003 ${ }^{\text {) }}$ e coelho (SASAHARA et al., 2003) e do período neonatal de uma determinada espécie (APPENZELLER, 1990; SZURSZEWSKI; KING, 1988), e de modo geral, o posicionamento do núcleo nos gânglios simpáticos é excêntricos (BURKITT; YOUNG; HEATH, 1994; COMARCK, 1987; GAGLIARDO et al., 2003; RIBEIRO et al., 2002; SASAHARA et al., 2003; WHEATER; BURKITT; DANIELS, 1994). No interior do núcleo, é encontrado um ou dois nucléolos (CASTRO; 2001; GAGLIARDO et al., 2003; MILLER et al., 1996; RIBEIRO et al., 2002, SASAHARA et al., 2003).

Cada neurônio ganglionar está envolvido pelos processos das células da glia, formando uma cápsula glial, juntamente com fibroblastos e colágeno (APPENZELLER; 1990, GABELLA, 1995; MIOLAN; NIEL, 1996; GAGLIARDO et al., 2003). Esta estrutura, juntamente com as fibras mielínicas, amielínicas e vasos caracterizam o neurópilo, que envolve o neurônio (GAGLIARDO et al., 2003). Dependendo do tamanho do neurônio ganglionar, pode haver um número maior ou menor de células da glia envolvendo (SZURSZEWSKI; MILLER, 1994).

\footnotetext{
${ }^{1}$ Informação fornecida por Ribeiro em comunicação pessoal, em 2003.
} 
As células da glia apresentam forma achatada e plana (MIOLAN; NIEL, 1996), tendo seu núcleo fortemente corado (MILLER et al., 1996) e são menores que os neurônios ganglionares e incapazes de iniciar potenciais de ação em resposta à corrente aplicada na membrana celular ou à estimulação nervosa pré-ganglionar (MILLER et al., 1996; MIOLAN; NIEL, 1996; SZURSZEWSKI; KING, 1988; SZURSZEWSKI; MILLER, 1994). Estas células limitam a difusão de fluídos extracelulares (GABELLA, 1995).

As células SIF são responsáveis por transferirem impulsos monoaminérgicos aos neurônios ganglionares (MIOLAN; NIEL, 1996). Estas células são identificadas pelo seu pequeno tamanho e pela grande quantidade de vesículas granulares ricas em aminas biogênicas (GABELLA, 1995; MIOLAN; NIEL, 1996; SZURSZEWSKI; KING, 1988; SZURSZEWSKI; MILLER, 1994).

Dois tipos de células SIF podem ser encontrados nos gânglios pré-vertebrais. O primeiro tipo forma aglomerados localizados em íntima proximidade com os capilares fenestrados, refletindo uma função neuroendócrina. Esse tipo de célula SIF não possui processos celulares, mas pode receber impulsos nervosos de fibras pré-ganglionares. O segundo tipo de célula SIF está distribuído esparsamente dentro do gânglio em íntimo contato com os dendritos, sugerindo que elas funcionem como interneuronios, enviando impulsos monoaminergicos para os neurônios (MIOLAN; NIEL, 1996; SZURSZEWSKI; KING, 1988; SZURSZEWSKI; MILLER, 1994).

As células SIF são classificadas de acordo com o tamanho das vesículas granulares existentes. A célula SIF tipo I apresenta apresentam vesículas medindo entre $80-100 \mathrm{~nm}$ de diâmetro, a célula SIF tipo II apresentam vesículas medindo de $150-300 \mathrm{~nm}$ de diâmetro. Há uma variedade no número de células SIF de acordo com o gânglio pré-vertebral e a espécie animal considerada (GABELLA, 1995). 
Os vasos sangüíneos encontrados nos gânglios simpáticos são na maioria capilares (GABELLA, 1995), vênulas pós-capilares, embora pequenas vênulas e arteríolas também estão presentes (BAKER; SANTER; BLAGGAN, 1989). Os capilares encontrados apresentam parede continua em sua grande maioria, sendo visto muito raramente vasos com fenestras (GABELLA et al., 1988; MILLER et al., 1996). Os capilares fenestrados são vistos próximos aos grupos de células SIF (SZURZEWSKI; KING, 1988; SZURSZEWSKI; MILLER, 1994).

\subsection{EFEITO DO DESENVOLVIMENTO (MATURAÇÃO E ENVELHECIMENTO) NOS NEURÔNIOS}

O envelhecimento é um processo inevitável nos mamíferos que está associado a alterações celulares e um declínio geral na fisiologia, levando a um aumento na incidência do aparecimento de doenças degenerativas (RUTTEN et al., 2003; SZWEDA et al., 2003). No sistema nervoso autônomo, as alterações clínicas com o aumento da idade podem ser exemplificadas com as alterações na motilidade do trato gastrointestinal, como a constipação (EL-SALHY; SANDSTRÖM; HOLMLUND, 1999; GEBOES; BOSSAERT, 1977; SANTER; BAKER, 1993), as alterações pupilares, sudomotoras, cardiovasculares, termorregulatórias, entre outras (SCHMIDT, 1991).

As mudanças neuronais verificadas nos gânglios simpáticos com o aumento da idade envolvem alterações no metabolismo celular, como um aumento ou uma diminuição na síntese de noradrenalina (SANTER; BAKER, 1993), as alterações na morfologia neuronal exemplificadas pela presença de axônios distróficos (SCHMIDT et al., 1983; SCHMIDT; DORSEY; ROTH, 1992), o aparecimento de pigmentos e figuras mielinícas, e as alterações 
ultra-estruturais principalmente em mitocôndrias, complexo de Golgi e retículo endoplasmático rugoso (SZWEDA et al., 2003; VEGA; CALZADA; DEL VALLE, 1993). Estas mudanças são denominadas de intrinsecas. Alterações no ambiente extracelular como o acúmulo de metabólicos ou deposição de componentes da matriz também são verificadas com 0 aumento da idade, sendo estas mudanças denominadas extrínsecas (CRUTCHER, 2002).

A progressão da idade está relacionada com uma diminuição da inervação simpática proveniente dos gânglios pré-vertebrais para os intestinos (SANTER; BAKER, 1993) e para a bexiga urinária (WARBURTON; SANTER, 1994). No entanto, tal evento não está relacionado unicamente com as alterações no metabolismo neuronal proveniente dos gânglios prévertebrais, mas também com alterações na víscera-alvo, podendo ser exemplificada pela baixa responsividade aos estímulos dos neurotransmissores nos intestinos (MCDOUGLAS et al., 1984). Ainda, as possíveis alterações clínicas com 0 aumento da idade podem estar vinculadas primariamente às alterações nos neurônios intrínsecos do órgão-alvo, onde nos intestinos, por exemplo, é verificado uma diminuição no número de neurônios no plexo mioentérico (GABELLA, 1989; EL-SALHY; SANDSTRÖM; HOLMLUND, 1999 )

As neuropatias autonômicas foram tipicamente refletidas com a diminuição no número de total de neurônios simpáticos, porém, poucas evidências de uma substancial perda neuronal com o aumento da idade foram encontradas (SCHMIDT et al, 1988). A diminuição no número de neurônios está relacionada muitas vezes as fases do desenvolvimento ou com o território de inervação alvo, e não com a senilidade (COWEN, 2002; CRUTCHER, 2002).

A possível perda de neurônios especulada com a progressão da idade não se relaciona com disfunção, ao contrário, esta funcionaria como uma estratégia para prevenir o declínio funcional, pois a disfunção está ligada ao acúmulo de macromoléculas dentro de certos tipos 
especificos de neurônios que não apresentam uma resposta apropriada para a lesão celular (apoptose) (RUTTEN et al., 2003).

A falsa idéia do declínio funcional associada à diminuição neuronal foi embasada em alguns trabalhos realizados antes de 1950 , onde estes demonstravam uma significante diminuição neuronal em humanos idosos não portadores da doença de Alzheimer. No entanto estes estudos informavam a densidade neuronal, erroneamente descrita como número total de neurônios (MORRISON; HOF, 1997). Posteriormente, uma série de métodos foi criada para se determinar o número total neurônios a partir de secções histológicas. A maioria destes utilizavam a determinação do número de perfis (nucléolo, núcleo ou célula) e, através de um fator de correção, convertiam estes valores ao número total de neurônios. Estes procedimentos foram derivados de fórmulas geométricas onde foi necessário assumir suposições, por exemplo, que o núcleo ou nucléolo eram redondos. A dificuldade é que estas suposições não são completamente corretas, fazendo com que os métodos não sejam imparciais (COGGESHALL, 1992; GUILLERY; HERRUP, 1997; MAYHEW; GUNDERSEN, 1996; POVER).

Dentre os métodos de quantificação anteriormente referidos podemos citar o método de Abercrombie (1946) e Koningsmark (1970), sendo o método de Abercrombie o mais citado em trabalhos científicos, seguido pelo método de Koningsmark (VON BARTHELD, 2002). No entanto, à falta de imparcialidade destes métodos faz com que os resultados sejam inacurados (POVER; COGGESHALL, 1991).

Com a publicação do trabalho de Sterio (1984), surgiram procedimentos estereológicos acurados que permitiram analisar os tecidos biológicos tridimensionalmente, permitindo quantificar o verdadeiro número de neurônios sem a necessidade de fazer suposições sobre a forma, orientação e tamanho da partícula, fornecendo resultados precisos (MAYHEW; 
GUNDERSEN, 1996; MOUTON, 2001). Dentre estes métodos, podemos citar o método disector (STERIO, 1984), o qual pode ser dividido em físico e óptico, e o método fracionador (COGGESHALL; LEKAN, 1996; GUNDERSEN et al., 1988a). O primeiro método citado fornece os resultados sobre o número total de uma determinada partícula de maneira indireta, isto é, através da multiplicação de duas variáveis, enquanto que o outro método fornece de maneira direta (MAYHEW, 1991 e 1992).

Através dos novos métodos estereológicos, verificou-se, por exemplo, que o declínio no número de neurônios, ao menos no neocórtex e hipocampo, não foi significatico com a progressão da idade (MORRISON; HOF, 1997). Da mesma forma, no sistema nervoso periférico não foram verificadas mudanças significativas no número total de neurônios com o aumento da idade nos gânglios cervical cranial de ratos (SANTER, 1991) e hipogástrico (WARBURTON; SANTER, 1997). Ainda, nos gânglios da raiz dorsal (L3-L6) foi verificada uma quantidade de neurônios maior e significativa nos ratos adultos do que nos ratos neonatos, sugerindo uma possível neurogênese (POPKEN; FAREL; 1997) ou uma incompleta diferenciação neuronal (FAREL, 2003).

O processo de envelhecimento nas estruturas celulares que compõem os gânglios do sistema nervoso periférico é pouco conhecido (GAVAZZI; COWEN, 1996) e difere entre os diferentes gânglios e entre as espécies (VEGA; CALZADA; DEL VALLE, 1993). O gânglio pré-vertebral mesentérico cranial de ratos, por exemplo, pode apresentar distrofia axonal com o aumento da idade, o que não é verificado no gânglio paravertebral cervical superior (SCHMIDT, 2002; SCHMIDT; DORSEY; ROTH, 1992; SCHMIDT et al 1993a; SCHMIDT et al 1993b), assim como ocorre diminuição na síntese de noradrenalina no gânglio celíaco mesentérico, não observado no gânglio cervical superior (VEGA; CALZADA; DEL VALLE, 1993). 
Além de existir diferenças entre os diversos gânglios, podem existir diferenças entre subpopulações neuronais dentro do gânglio, como visto no gânglio cervical cranial de ratos, onde subpopulação de neurônios responsável pela inervação da íris não apresentam atrofia, diferentemente da subpopulação na qual os neurônios projetam para a artéria cerebral média (ANDREWS, 1996; ANDREWS et al., 1996). Tais alterações estão possivelmente relacionadas com a produção de fatores neurotrópicos por determinados tecidos (ANDREWS, 1996; BENNETT; GIBSON; LEMON, 2003; COWEN, 2002; CRUTCHER, 2002; GAVAZZI; COWEN, 1996) e por elementos da matriz extracelular (CRUTCHER, 2002; GRAVAZZI; COWEN, 1996).

O genótipo do animal, mesmo se tratando da mesma espécie, também pode influenciar nas mudanças neuronais, como verificado em ratos C57BL onde a idade superior a 24 meses leva a uma atrofia nos neurônios colinérgicos do prosencefalo o que não acontece em outros tipos de ratos como o F344, WKY e o BN (FINCH, 1993).

Nas etapas iniciais do desenvolvimento ocorre um modelamento no número total de neurônios, pois ainda há muitos neurônios se dividindo e conseqüentemente muitos sendo excluidos. Aproximadamente mais de $50 \%$ da quantidade total de neurônios é excedente no início do desenvolvimento, sendo estes neurônios eliminados após alcançarem o órgão de inervação alvo. A morte neuronal se relaciona à competição pelos fatores neurotrópicos. $\mathrm{O}$ completo desenvolvimento neuronal nos gânglios simpáticos difere entre as espécies. Em ratos, é sabido que um grande número de neurônios degeneram no terceiro dia pós-natal (WRIGHT; CUNNINGHAM; SMOLEN, 1983) e que o número total de neurônios é estabelecido no primeiro mês pós-parto. Durante a maturação neuronal há um aumento no diâmetro do corpo celular e do núcleo, e uma diminuição na densidade de neurônios por área 
(BAKER; SANTER, 1988; DAVIES², 1978 apud VEGA; CALZADA; DEL VALLE, 1993). Já em gatos, o número de neurônios é máximo nos recém-nascidos, diminuindo posteriormente e tendo a partir do $20^{\circ}$ dia o mesmo número de neurônios encontrado em um animal adulto. Durante este periodo de desenvolvimento, da mesma maneira que ocorre no rato, há um aumento no tamanho do neurônio, com uma correspondente diminuição na densidade por área (MASLIUKOV, 2001).

A diminuição na densidade neuronal por área ("packing density") ou por volume está relacionada ao aumento do tamanho do neurônio e/ou uma proliferação de tecido intersticial (SANTER, 1991; WEST, 1994). Esta diminuição pode ser ou não verificada com o aumento da idade (BAKER; SANTER, 1988; SCHMIDT et al., 1993b; SOLTANPOUR; BAKER; SANTER, 1996; WARBURTON; SANTER, 1997).

A atrofia neuronal não é restrita a senescência, embora muitas vezes correlacionada. Os neurônios podem se atrofiar em determinados períodos da vida e esta atrofia não precede a morte celular (FINCH, 1993). Muitas vezes a atrofia neuronal verificada nos cortes histológicos pode estar relacionada à fixação e o processamento do tecido pós-morte (FINCH, 1993; GARDELLA et al., 2003; GUILLERY; HERRUP, 1997; SCHMALBRUCH, 1987; VON BARTHELD, 2002), ou a diminuição da produção de substâncias neurotrópicas por alguns neurônios (CRUTCHER, 2002; FINCH, 1993) ou ainda perda da afinidade dos neurônios ao NGF (nerve growth factor) por problemas em receptores (VEGA; CALZADA; DEL VALLE, 1993).

Problemas na microperfusão também são uma das possíveis causas da atrofia neuronal. Recentes trabalhos demonstram que a densidade das arteríolas do córtex cerebral e capilares diminui em torno de $35 \%$ em ratos velhos e apresentam um aumento na hialinização. Uma

\footnotetext{
${ }^{2}$ DAVIES, D.C. Neuronal numbers in the superior cervical ganglion of the neonatal rat. J. Anat., v. 127, n. 43, 1978.
} 
outra plausível causa da atrofia são as alterações no mecanismo hormonal com o aumento da idade (FINCH, 1993).

O aumento no tamanho do neurônio é coerente com as fases iniciais do desenvolvimento, pois no processo de maturação há um aumento no tamanho deste e de seu núcleo (MASLIUKOV, 2001; VEGA; CALZADA; DEL VALLE, 1993). Contudo, a hipertrofia neuronal também pode ser verificada na senilidade, ocorrendo esta paralelamente com a diminuição no número de neurônios ou estando relacionada a um alargamento do corpo celular devido aos depósitos de pigmentos (FINCH, 1993; WARBURTON; SANTER, 1997).

$\mathrm{O}$ acúmulo de pigmentos (produto da condensação de proteínas, fosfolipídios e produto da peroxidação lipíca) no interior do neurônio é uma mudança citológica freqüentemente correlacionada com a idade, sendo a formação do pigmento lipofucsina um processo contínuo. Já a neuromelanina é um pigmento que só aparece nos neurônios adrenérgicos, sendo um produto da auto-oxidação das catecolaminas, tendo no precursor deste pigmento a toxidade celular e levando a morte neuronal (SCHMIDT et al. 1993b, 1996; SOLTANPOUR; BAKER; SANTER, 1996; SZWEDA et al., 2003; VEGA; CALZADA; DEL VALLE, 1993).

Em um animal adulto, a proporção ocupada pelo núcleo no interior da célula é bastante pequena (PEVZNER, 1980), e com o aumento da idade a relação volumétrica entre núcleocitoplasma diminui progressivamente, possivelmente a um aumento maior no corpo celular (LEDDA et al., 2000) ou a uma diminuição do núcleo devido a uma perda de DNA (ALBERTS et al., 1994; FINCH, 1993; LEDDA et al., 2000). No entanto, é sabido que nas fases de maturação celular é encontrado um aumento no volume nuclear (MCMAHON; DOCKERY; DERMOTT, 2003), como verificado nos neurônios motores de ratos de 20 a 120 dias (MAYHEW, 1989), junto ao aumento do perfil neuronal (BAKER; SANTER, 1988). 
Desta forma, a diminuição do núcleo com o aumento da idade sugere a diminuição da atividade de alguns genes (FINCH, 1993). 
MATERIAL E MÉTODOS 


\section{MATERIAL E MÉTODOS}

Neste capítulo estão relatados o material e os diferentes métodos que foram utilizados, para a devida realização desta pesquisa e obtenção dos resultados esperados.

\subsection{MATERIAL}

Foram coletados nove gânglios mesentéricos caudais (GMC) provenientes de nove cães domésticos (Canis familiaris), sem raça definida (SRD) e machos, oriundos do Hospital Veterinário da Faculdade de Medicina Veterinária e Zootecnia da Universidade de São Paulo (HOVET-FMVZ-USP). Os animais (e seus respectivos gânglios coletados) foram separados em grupos etários bem diferenciados, pelo fato de serem animais provenientes do hospital veterinário e com ficha clínica muito bem definida, visando elucidar as possiveis alterações decorrentes do desenvolvimento, isto é, da maturação e envelhecimento. Os animais considerados nesta pesquisa não apresentavam histórico ou sinais clínicos compativeis com qualquer neuropatia.

- Grupo I (filhotes) - três cães com idades entre $1-2$ meses $(0,15-0,18 \mathrm{Kg})$.

- Grupo II (adultos) - três cães com idades entre 1 - 3 anos (13-18 Kg).

- Grupo III (senis) - três cães com idades entre 5 - 10 anos $(17-23 \mathrm{Kg})$. 


\subsection{MÉTODOS}

Os métodos foram divididos em quatro etapas: estudo histológico, estudo morfométrico, estudo estereológico e análise estatística.

\subsection{ESTUDO HISTOLÓGICO}

As etapas do estudo histológico foram divididas em: lavagem do sistema circulatório e fixação do gânglio por meio de perfusão, processamento do material e microscopia de luz de cortes semi-finos.

\subsubsection{LAVAGEM DO SISTEMA CIRCULATório E FIXAÇÃo do GÂNGLIO POR MEIO DE PERFUSÃO}

Imediatamente após o óbito dos animais no HOVET-FMVZ-USP, a cavidade abdominal foi exposta através de uma incisão na linha alba (celiotomia pré-retroumbilical) visando a localização dos principais vasos arteriais e venosos do abdome. A aorta abdominal foi canalizada e mantida em posição por meio de um fio de algodão próximo à emergência da artéria mesentérica caudal e, posteriormente, a veia cava caudal foi seccionada. Ainda, a porção da aorta abdominal caudal a emergência da artéria mesentérica caudal foi laqueada utilizando fio de algodão. Uma solução contendo solução salina tamponada fosfatada (PBS)

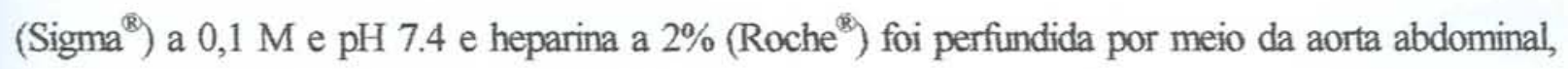


possibilitando a lavagem dos sistemas arterial e venoso. Em seguida, a solução fixadora de Karnovsky modificada, constituída por glutaraldeido $5 \%{\text { ( } \text { Merck }^{8} \text { ) e formoldeido a } 1 \% \text { (Sigma }}^{\mathbb{Q}^{2}}$ ) em tampão cacodilato de sódio $\left(\mathrm{EMS}^{\circledR}\right)$ a $0,125 \mathrm{M}$ e pH 7.4 foi perfundida nos animais, através do mesmo vaso utilizado para a solução de lavagem, no entanto, para a perfusão do fixador a veia cava caudal foi laqueada.

\subsubsection{PROCESSAMENTO DO MATERIAL}

Após a perfusão da solução fixadora de Kamovsky modificada, o GMC foi dissecado "in situ" juntamente com suas conecções nervosas (nervos hipogástricos, intermesentéricos e esplâncnicos lombares) e removidos. Os gânglios pertencentes aos grupos II e III foram seccionados transversalmente com a utilização de uma lâmina cortante, originando cinco fatias ganglionares com uma distância média, na maioria dos gânglios de $2,5 \mathrm{~mm}$, para promover a estimativa do volume, posteriormente descrita, e após, assim como os gânglios do grupo I, foram imersos na mesma solução fixadora utilizada para a perfusão, onde permaneceram durante um período mínimo de 72 horas.

Posteriormente, os fragmentos ganglionares pertencentes aos grupos II e III e os gânglios do grupo I foram lavados em solução tampão de cacodilato de sódio $\left(\mathrm{EMS}^{\mathrm{Q}}\right)$ a $0,125 \mathrm{M}$ e pH 7,4 e imersos em uma solução aquosa de tetróxido de ósmio a $2 \%\left(\mathrm{EMS}^{\mathrm{Q}}\right)$. As amostras permaneceram nesta solução durante 60 minutos, no escuro e sob agitação constante. Em seguida, foram lavados na mesma solução de tampão de cacodilato anteriormente referida, seguido de água destilada, para serem contrastados em blocos com a solução aquosa saturada de acetato de uranila (Reagen ${ }^{(8)}$ ) durante 60 minutos sob agitação constante e em recipiente escuro. 
Os espécimes foram lavados com água destilada e desidratados em série crescente de etanóis ( $50 \%$ em 10 minutos, $70 \%$ em 10 minutos, $90 \%$ em 10 minutos e $100 \%$ em 20 minutos), sendo depois desidratados em óxido de propileno $\left(\mathrm{EMS}^{\text {(n) }}\right)$ por 10 minutos.

As amostras foram embebidas com uma solução de óxido de propileno $\left(\mathrm{EMS}^{\circledR}\right.$ ) e resina araldite (502 Polyscience Inc. ${ }^{8}$ ), em constante agitação e em diferentes proporções. Após estas etapas, os espécimes foram transferidos para resina araldite pura (502 Polyscience Inc. ${ }^{(R)}$ ) e levados à estufa $\left(60^{\circ} \mathrm{C}\right)$, permanecendo durante um período mínimo de dois dias.

\subsubsection{MICROSCOPIA DE LUZ DE CORTES SEMI-FINOS}

Todos os blocos provenientes do material processado, isto é, os blocos constituídos pelos gânglios inteiros do grupo I e os blocos contendo os fragmentos ganglionares (previamente seccionados) pertencentes aos grupos II e III, foram trimados para evidenciar as regiões de interesse e seccionados seriadamente com dois micrometros de espessura, com o auxilio do ultra-microtomo MT$\mathrm{XL}$ equipado com um contador de secções e usando navalha de vidro. A seguir, as secções foram coletadas sobre lâminas e coradas com uma solução de azul de toluidina alcoólica. Posteriormente, foram cobertas com uma gota de araldite (502 Polyscience Inc. ) e montados sob lamínula.

\subsubsection{ESTUDO MORFOMÉTRICO}

A partir de 30 seç̧ões seriadas com dois micrometros de espessura, uma área foi escolhida sistematicamente e aleatoriamente para promover a análise morfométrica. Esta foi 
delimitada por uma área teste $\left(\mathrm{A}_{\mathrm{t}}\right)$ constituída por linhas de inclusão e exclusão, sendo considerados apenas os perfis que estavam dentro da área teste e que não tocavam nas linhas de exclusão (Figura 1A). Os neurônios contidos nesta área foram numerados individualmente, cada um recebendo um número no qual se repetia nas diferentes secções de análise quando se tratava do mesmo perfil neuronal (GABELLA; BERGGREN; UVELIUS, 1992; GABELLA; TRIGG; MCPHAIL, 1988).

As três primeiras e as três últimas secções não foram consideradas para a análise morfométrica, seguindo o princípio do "brick" (HOWARD et al., 1985), que é uma derivação do trabalho de Gundersen (1977) aplicado ao plano tridimensional. Desta forma, foram analisadas 24 secções, sendo que os neurônios foram considerados para o cálculo da área seccional do corpo neuronal e área seccional do núcleo, ou ainda para a medida de eixos maior ou menor, nas secções onde seu perfil era máximo.

Os dados morfométricos foram obtidos com o auxilio do Programa para processamento e análise de imagens KS-400 Zeiss ${ }^{(\$)}$, devidamente calibrado com uma régua milimetrada. As imagens foram capturadas com o auxilio do microscópio óptico Axioscópio Zeiss ${ }^{\circledR}$ (Objetiva 20X) e de uma câmara digital TK 1280 OU JVC ${ }^{\circledR}$ na qual transferia a imagem para uma tela de computador. Foram mensurados 54 neurônios por gânglio (162 por grupo) e 33 núcleos por gânglio ( 99 núcleos por grupo), provenientes de três diferentes regiões de cada secção, escolhidas sistematicamente e aleatoriamente. Desta forma, foram analisados um total de 486 neurônios e 297 núcleos nesta pesquisa.

A obtenção dos eixos do perfil neuronal se fez necessária para a obtenção do formato do perfil neuronal ou "form factor" (GABELLA; TRIGG; MCPHAIL, 1988), também chamado de coeficiente de "roundness" (MASLIUKOV, 2000) ou "shape factor" (MCMAHON; DOCKERY; MCDERMOTT, 2003), onde este foi obtido através da divisão do eixo menor 
pelo eixo maior. O valor deste fator ou coeficiente varia de quase zero a um, tendo em um a forma de uma círculo perfeito.

A relação núcleo-citoplasma também foi verificada. Para a obtenção desta, foi calculado primeiramente a área seccional do citoplasma obtida por meio da subtração da área seccional do corpo do neurônio pela área seccional do núcleo. Após, foi feita a relação entre a área do núcleo e a área do citoplasma.

\subsubsection{ESTUDO ESTEREOLÓGICO}

As etapas do estudo estereológico foram divididas em: quantificação neuronal (método do disector físico associado ao volume referência), densidade numérica ou densidade neuronal, volume do espaço referência ou ganglionar (método de Scherle e método de Cavalieri), estimativa do número total de neurônios, estimativa da densidade de volume e estimativa indireta do volume neuronal médio.

\subsubsection{QUANTIFICAÇÃO NEURONAL (MÉTODO DO DISECTOR FÍSICO ASSOCIADO AO VOLUME REFERÊNCIA)}

A quantificação neuronal no GMC de cães nos diferentes grupos etários foi realizada utilizando o método estereológico do disector físico, descrito inicialmente por Sterio (1984) e por Pakkenberg e Gundersen $(1988,1989)$, associado ao volume referência. O método do disector permite contar partículas independentemente do tamanho, forma, distribuição ou 
orientação, em um volume conhecido, utilizando pares de secções provenientes de cortes seriados (COGGESHALL, 1991 e 1992; COGGESHALL; LEKAN, 1996; MAYHEW, 1992; MAYHEW; GUNDERSEN, 1996; PAKKENBERG; GUNDERSEN, 1988; POVER; COGGESHALL, 1991).

Através do método disector físico, a densidade numérica foi estimada. Para se determinar esta, é necessário contar o número de "transects" (ou "Q-") em cada disector (cada disector é constituído por duas secções idênticas separadas por uma altura conhecida, sendo estas secções denominadas de "reference-section" e "look-up secction"; e "transects" são as partículas encontradas na "reference-section", mas não na "look-up section") (Figura 1 e 2). Posteriormente a soma do número de "transects" é dividida pela soma dos volumes dos disectors (o volume do disector refere-se ao produto da área teste utilizada na "reference section" pela altura do disector) (Equações 1 e 2). Já para obter-se o volume referência, diferentes métodos são encontrados na literatura, como por exemplo, o método de Scherle e o método de Cavalieri, ambos descritos posteriormente.

$$
\mathrm{Nv}=\frac{\sum \mathrm{Q}^{-}}{\sum \mathrm{V}_{(\mathrm{dis})}}
$$

Equação 1

$$
\mathrm{V}_{(\mathrm{dis})}=h \times \mathrm{A}_{\mathrm{t}}
$$

Equação 2

A unidade de quantificação ou contagem considerada nesta pesquisa foi o corpo neuronal (pericário). A observação do material e a captura da imagem foram realizadas com o auxílio do microscópio Axioscópio Zeiss ${ }^{\circledR}$ e de uma câmara digital TK 12800 U JVC $^{\circledR}$, na qual a imagem da "reference section" era capturada e transferida para a tela de um computador. Sobre a tela, era aplicada uma área teste (com linhas de inclusão e exclusão) e os 
perfis dos corpos celulares presentes na "reference section" eram desenhados através da sobreposição de uma transparência. Posteriormente, a imagem da "look-up section" era capturada e comparada com a "reference section" desenhada na transparência. Desta forma, o número de "transects" foi obtido.
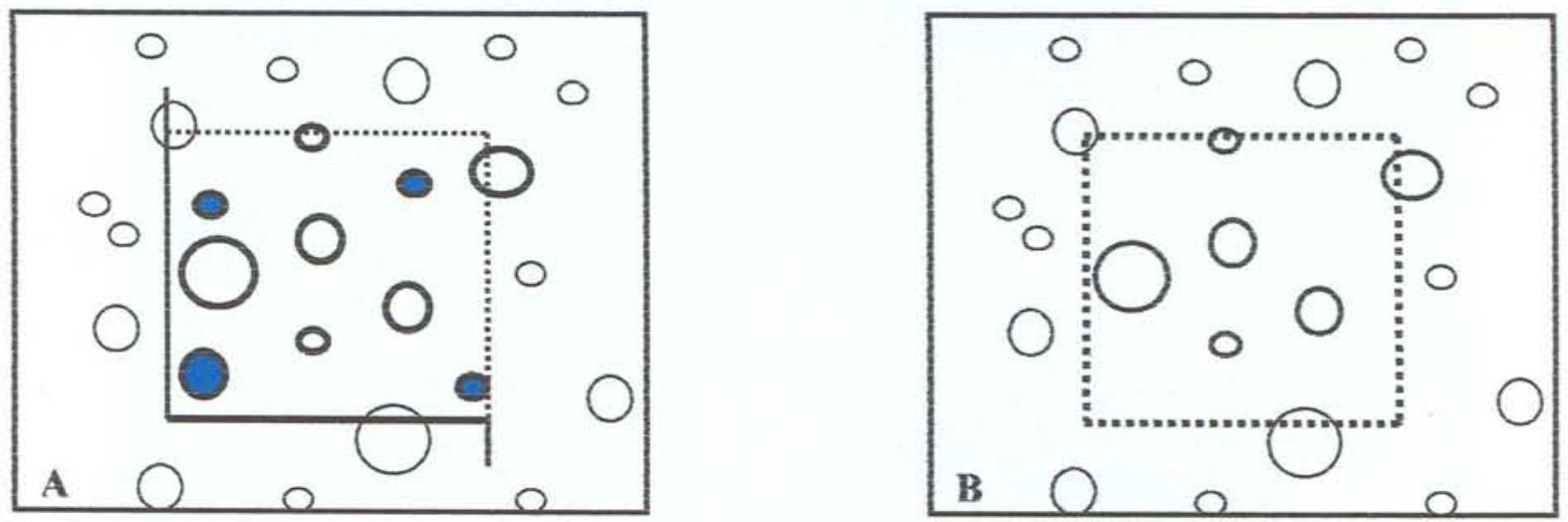

Figura 1 (A-B) - Quantificação do número de "transects" (ou Q-) no disector. A "reference section", demonstrada na figura "A", é delimitada por uma área teste constituída por linhas de inclusão (linhas pontilhadas) e de exclusão (linhas cheias). Os perfis neuronais que tocam as linhas de exclusão não são considerados. Neste esquema somente os perfis em negritos foram analisados. A figura " $\mathrm{B}$ " representa a "look-up section", onde esta não é delimitada por uma área teste rígida como visto na figura "A", embora exista. Para quantificar os "transects", é necessário contar o número de perfis vistos na "reference section" (A) e não encontrados na "look-up section" (B). Neste esquema foram contados quatro "transects" ou partículas, sendo estes pintados de azul. Note ainda que além da área teste utilizada na figura "A", é necessário uma "guard" área em torno da mesma. 

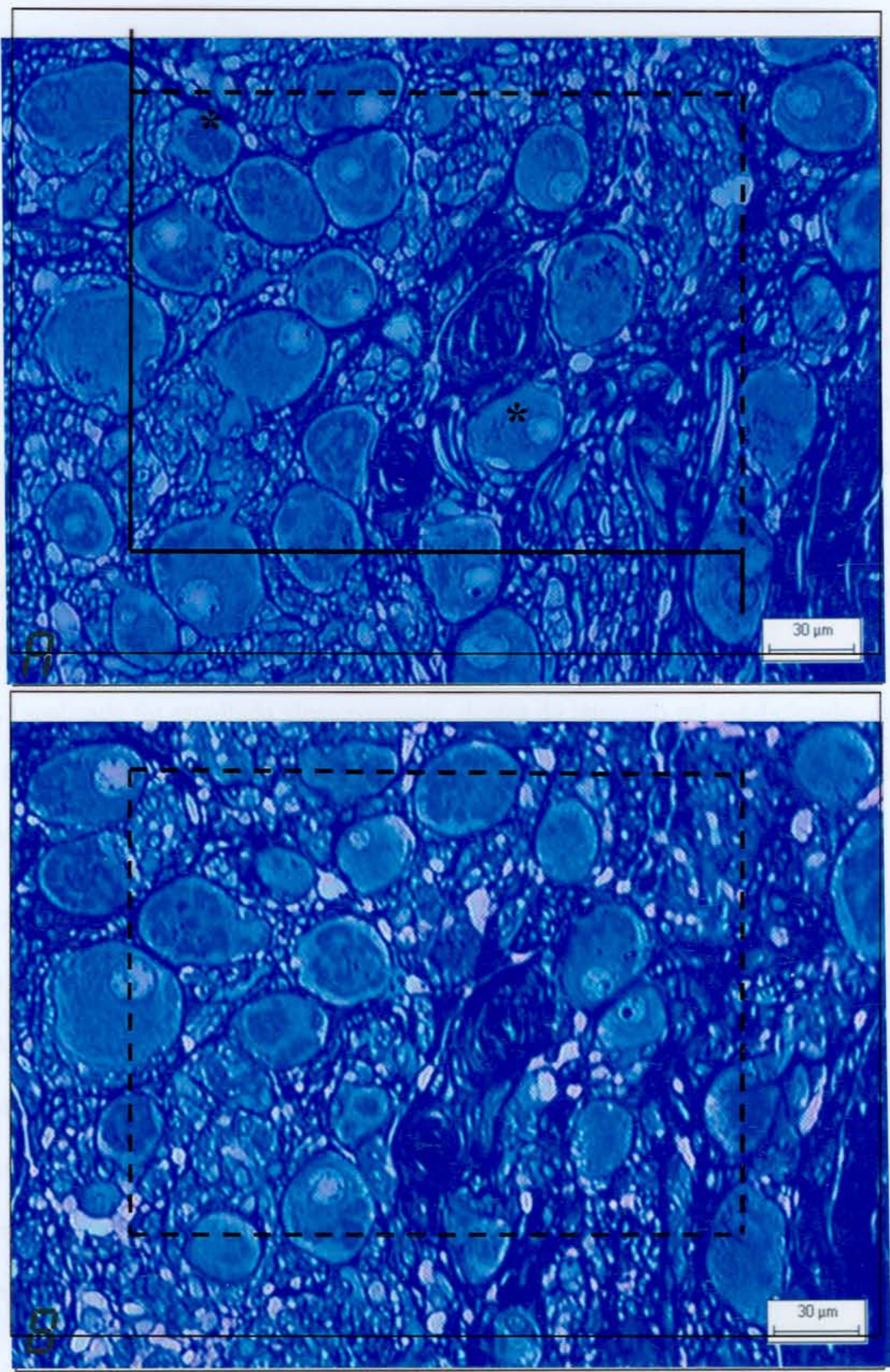

Figura 2 (A-B) - Fotomicrografias utilizadas para quantificação do número de "transects" (ou Q"). Em "A" a "reference section" e em "B" a "look-up section". A altura $(h)$ do disector é $10 \mu \mathrm{m}$. Os neurônios vistos em "A" e não em "B" estão marcados (*). 

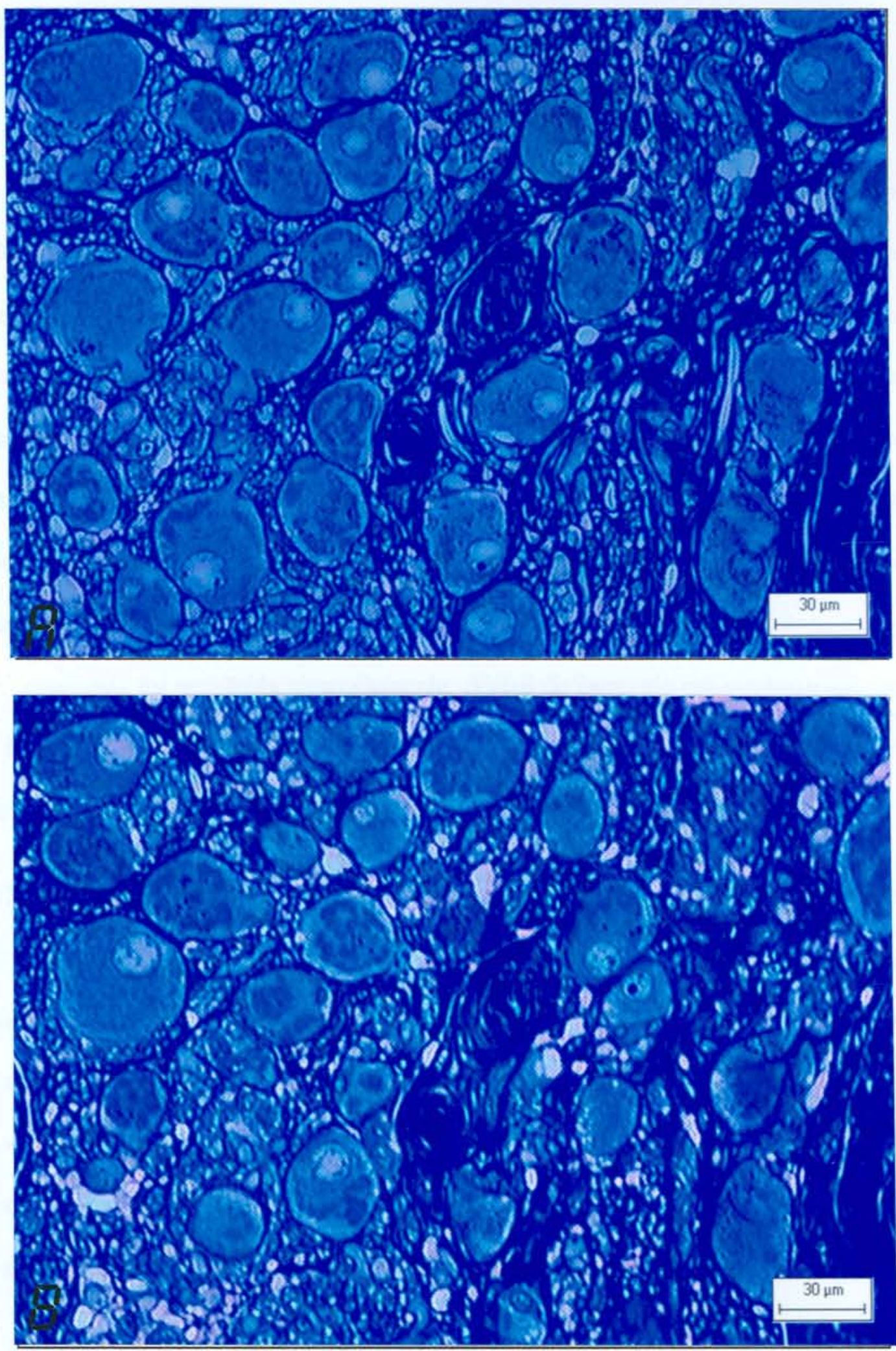

Figura 2 (A-B) - Fotomicrografias utilizadas para quantificação do número de "transects" (ou Q"). Em "A" a "reference section" e em "B" a "look-up section". A altura $(h)$ do disector é $10 \mu \mathrm{m}$. Os neurônios vistos em "A" e não em "B" estão marcados (*). 


\subsubsection{DENSIDADE NUMÉRICA OU DENSIDADE NEURONAL (Nv)}

Para determinar a Nv, neste trabalho definida como o número de neurônios por unidade de volume (unidade utilizada: $\mathrm{mm}^{3}$ ), os disectors foram aplicados por toda extensão do gânglio, para permitir que todas as regiões apresentassem as mesmas chances de serem amostradas, obedecendo um sistema de amostragem denominado "systematic random sampling scheme" (MAYHEW; GUNDERSEN, 1996), mencionado de maneira similar por Gundersen et al. (1988), Gundersen et al. (1999), Pakkenberg e Gundersen (1988, 1989) e Pover e Coggeshall (1991). Para isso, fez-se necessário estabelecer um intervalo $(k)$ entre as "reference sections" ao longo dos disectors utilizados, sendo que a primeira "reference section" analisada foi escolhida aleatoriamente, dentro do intervalo pré-estabelecido, que vai de 1 a $k$, como preconizado por Gundersen et al. (1988a), Pakkenberg e Gundersen (1988) e Pover e Coggeshall (1991).

De acordo com Gundersen et al. (1988a) e Mayhew e Gundersen (1996) uma população de 100 a 200 células deve ser contado para estimar a Nv. Assim sendo, é imperativa a necessidade de um estudo piloto para se saber a quantidade de disectors utilizada para atingir este número populacional. Neste trabalho, foi determinado que em torno de 34 disectors nos gânglios pertencentes ao grupo I e de 20 disectors para os gânglios do grupo II e III (4 disectors por fatia ganglionar) forneceriam uma contagem ideal, isto é, uma quantidade minima de 100 células.

Sabendo da quantidade de disectors necessária e o tamanho do gânglio, este mensurado com a utilização de um paquímetro digital (Starret ${ }^{\text {(8) }}$, foi possível delimitar um intervalo de secções no qual permitiu que todas as regiões do gânglio fossem amostradas. Desta forma, foi utilizado um $k=100$ para os gânglios provenientes do grupo I e um $k=250$ para os gânglios 
pertencentes aos grupos II e III. A primeira secção de análise do disector, em todo os grupos, foi escolhida de maneira aleatoria como descrito anteriormente. Deste modo, por exemplo, no grupo I um número entre $1-100(k=100)$ foi sorteado, por exemplo o número 89 . Então as "reference sections" dos disectors foram $89,189,289,389$ e assim progressivamente. Da mesma forma foi realizado nos grupos II e III.

A altura do disector $(h)$ utilizada, como preconizado por Gundersen et al. (1988a) e Mayhew e Gundersen (1996), não deve ser maior que o tamanho da menor partícula a ser estudada, devendo ter de $1 / 3$ a $1 / 4$ do tamanho da maior partícula. Assim sendo, fez-se necessário um estudo morfométrico prévio dos neurônios ganglionares encontrados nos diferentes grupos etários para se saber qual o tamanho máximo e mínimo destes neurônios. Desta forma, foi fixado que a altura utilizada no disector, em todos os grupos, seria de $10 \mu \mathrm{m}$.

A área teste $\left(A_{t}\right)$, neste trabalho e neste tipo de abordagem, foi definida apenas na "reference section", sendo esta constituída por linhas de inclusão e exclusão (Figura 1A), para permitir uma igual chance de amostragem dos neurônios, independente do tamanho destes, em uma abordagem imparcial. Ainda, ao redor desta deve haver uma "guard" área, para permitir a completa visualização dos perfis neurônais (GUNDERSEN, 1977; HOWARD; REED, 1998). Foi utilizada neste trabalho uma $A_{4}$ de $1 \times 10^{-2} \mathrm{~mm}^{2}$ (Objetiva $40 \mathrm{X}$ ) para o grupo I e de $4 \times 10^{-2} \mathrm{~mm}^{2}$ para os grupos II e III (Objetiva 20X), permitindo uma a identificação de no mínimo 8 -10 perfis neuronais por área.

$O$ volume do disector $\left(V_{(\text {dis })}\right)$ neste trabalho foi de $1 \times 10^{-4} \mathrm{~mm}^{3}$ no grupo I e 4 X $10^{-4}$ $\mathrm{mm}^{3}$ nos grupos $I 1$ e $I I I$. 


\subsubsection{VOLUME DO ESPAÇO REFERENCIA OU GANGLIONAR (Vref)}

Dois métodos para a estimativa do volume referência do gânglio foram empregados visando à verificação do método mais acurado em relação ao material em estudo.

\subsection{MÉTODO DE SCHERLE}

De acordo com o método proposto por Scherle (1970), o volume pode ser verificado através do deslocamento de água causado pelo peso do material a ser avaliado. Seguindo o método, um recipiente contendo solução salina isotônica foi pesado usando uma balança analítica de precisão. Após, a balança foi zerada (tarada) e foi adicionado a este conjunto o GMC suspenso por um fio, tendo o cuidado deste não tocar nas paredes do recipiente. Sabendo que o volume é a razão entre o peso e a gravidade específica, e que a gravidade específica para órgãos sólidos imersos em solução salina isotônica é de 1,0048 (WEIBEL, 1979), pode-se afirmar que o volume do material é igual ao seu peso. O peso final verificado na balança em gramas, corresponde ao volume do gânglio analisado em $\mathrm{ml}$. Sabendo que $1 \mathrm{~cm}^{3}$ corresponde a $1 \mathrm{ml}$, os valores obtidos na balança em gramas foram transformados em $\mathrm{cm}^{3}$ e posteriormente em $\mathrm{mm}^{3}$ para adequação aos valores da densidade neuronal. 


\subsection{MÉTODO DE CAVALIERI}

De acordo com o matemático Cavalieri ${ }^{3}$ (1635 apud HOWARD; REED, 1998), o volume de qualquer objeto pode ser estimado através de uma exaustiva série de secções paralelas separadas por uma distância conhecida. A estimativa se dá pela distância entre as secções ( $d$ ou $k$, sendo $d$ a nomenclatura utilizada para cortes macroscópicos e $k$ para cortes microscópicos) multiplicada pela somatória das áreas ( $\mathrm{a}$ ) de cada secção (Equação 3).

$$
\text { Vref }=d(\text { ou } k) \times \Sigma \mathrm{a}
$$

Equação 3

Os gânglios provenientes dos grupos II e III, após a retirada dos animais, foram seccionados transversalmente por meio de planos macroscópicos paralelos e seriados, como descrito no trabalho de Henery e Mayhew, (1989), Mayhew (1992), Mayhew e Olsen (1991) e Mayhew, Mwamengele e Dantzer (1990). Cada gânglio originou assim cinco fatias ganglionares, que constitui uma estimativa eficiente para o cálculo do volume ganglionar pelo método de Cavalieri (HENERY; MAYHEW, 1989; GUNDERSEN; JENSEN, 1987; MAYHEW, 1992; MAYHEW; OLSEN, 1991). À distância entre as fatias (d) não foi possível ser obtida precisamente, então, como proposto por Gundersen et al. (1988b) e Mayhew e Olsen (1991), uma distância média (d) entre as fatias foi estimada através da mensuração do comprimento total do gânglio, com o auxilio de um paquímetro digital da marca Starrett ${ }^{(2}$, dividido pelo número total de fatias. A distância média utilizada na maioria dos gânglios foi

\footnotetext{
${ }^{3}$ CAVALIERI, B. (1635). Geometria indivisibilibus continuourum. Types Clementis Ferronii. Bononi. Reprinted, 1966 as Geometria degii indivisibili. Unioni Tipografica-Editrice Torinise, Torino.
} 
de 2,5mm. A área das fatias de apenas uma das faces foi calculada, isto é, apenas na face caudal de cada fatia (Figura 3).

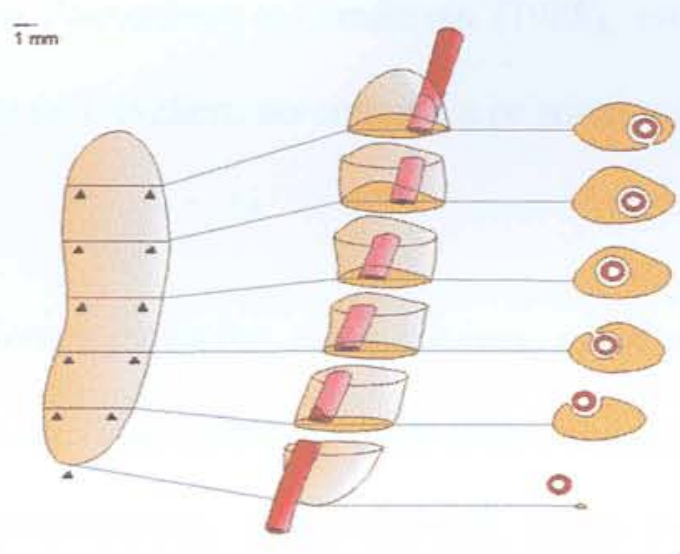

Figura 3 - Estimativa do volume pelo método de Cavalieri. Em "A" e "B" o gânglio mesentérico caudal foi cortado sistematicamente e transversalmente originando cinco fatias ganglionares paralelas $\mathrm{e}$ de mesma espessura, $d$. Para estimar o volume, a área seccional de cada fatia ganglionar foi calculada usando apenas uma das faces, a face mais caudal de cada fatia (cabeças de seta). Em "C" a área de secção tranversal da face caudal dos fragmentos foi calculada, tendo o cuidado de não incluir a área seccional da artéria mesentérica caudal, a qual atravessava o gânglio em todo o seu comprimento (escala $1 \mathrm{~mm}$ ).

O volume referência dos gânglios pertencentes ao grupo I foi obtido através da análise microscópica, por esta razão os gânglios foram previamente processados segundo o protocolo pré-estabelecido para a microscopia de luz de cortes semi-finos, sendo inteiramente incluídos seguindo a orientação cranio-caudal. Após, estes foram seccionados exaustivamente com dois micrometros de espessura ao longo do comprimento usando um ultra-microtomo $\mathrm{MT}-\mathrm{XI}{ }^{\text {(ब) }}$ equipado com um contador de secções e navalha de vidro. A primeira secção, onde o tecido ganglionar foi identificado histologicamente, foi amostrada, e a partir dela um intervalo entre as seções $(k)$ foi determinado. O intervalo utilizado foi um $k=200$, no qual corresponde a uma distância de 400 um para o cálculo do volume pelo método de Cavalieri. 
Quando a secção escolhida apresentou algum problema de qualidade, foi pego a secção subseqüente para a análise, por exemplo, se a secção 287 apresentava má qualidade, a secção 288 foi amostrada. Segundo Pakkenberg e Gundersen (1988), esta manobra não altera os dados obtidos com o método de Cavalieri, no entanto, a próxima secção a ser pega deve ser a 487 , e não a 488.

As secções obtidas foram montadas sobre lâminas, coradas com a solução azul de toluidina alcoólica, cobertas com uma gota de araldite (502 Polyscience Inc. ${ }^{8}$ ) e montados sob lamínulas, como descrito anteriormente. Posteriormente, foram observadas no microscópio para permitir o cálculo da área das secções.

A acuracia dos resultados obtidos pelo método de Cavalieri foi verificada através do coeficiente de erro. Este foi calculado através da equação proposta inicialmente por Gundersen e Jensen (1987), e descrita posteriormente em outros trabalhos como Cruz Orive (1993), Duerstock et al., (2003); Mayhew e Olsen (1991), Pakkenberg et al. (1989), Roberts et al. (1993) e Roberts et al. (1994) (Equação 4).

$$
\mathrm{CE}=1 / \Sigma \boldsymbol{A} \times[1 / 12(3 a+c-4 b)]^{1 / 2}
$$

Equação 4

$\Sigma \mathrm{A}=$ Somatória de todas $\mathrm{s}$ áreas das secções a

$\mathrm{a}=$ Somatória dos produtos de $\mathrm{a} \times \mathrm{a}$

$\mathrm{b}=$ Somatória dos produtos de $\mathrm{a} \times(\mathrm{a}+1)$

$\mathrm{c}=$ Somatória dos produtos de $\mathrm{a} \times(\mathrm{a}+2)$ 


\subsection{CÁlCULO DA ÁREA SECCIONAL}

Para se obter a estimativa do volume referência pelo método de Cavalieri, faz-se necessário o cálculo da área de cada secção. Para isto, foi utilizado o software especifico para morfometria KS-400 Zeiss ${ }^{\circledR}$. A imagem da superficie da secção do GMC no grupo I foi capturada com o auxílio do microscópio Axioscópio Zeiss ${ }^{(8)}$ (objetiva $2 \mathrm{X}$ ) e nos grupos II e III através de um microscópio estereoscópio Stemi SV 6 Zeiss ${ }^{\circledR}$ (L08). As imagens foram transferidas ao computador por meio de uma câmera digital TK 12800 U JVC $^{\circledR}$. O software de morfometria foi calibrado com o auxílio de uma lâmina de calibragem. O perímetro da imagem foi contornado e, posteriormente, a área seccional foi calculada automaticamente. As secções que continham a artéria mesentérica caudal no seu interior tiveram a área da artéria subtraída no cálculo da área de secção transversal ganglionar.

\subsubsection{ESTIMATIVA DO NÚMERO TOTAL DE NEURÔNIOS}

A estimativa do número total de neurônios $(\mathrm{N})$ no $\mathrm{GMC}$ de cães se deu através do produto entre a densidade numérica (Nv) (número de neurônios $/ \mathrm{mm}^{3}$ ) pelo volume referência (Vref) ou volume ganglionar (Equação 5).

$$
\mathrm{N}=\mathrm{Nv} \times \text { Vref }
$$

Equação 5 


\subsubsection{ESTIMATIVA DA DENSIDADE DE VOLUME (Vv)}

As "reference sections" anteriormente desenhadas em transparências para o cálculo da densidade numérica $(\mathrm{Nv})$ foram utilizadas para estimar a densidade de volume dos neurônios no GMC. A densidade de volume corresponde à fração de volume total do GMC ocupada por neurônios. Como descrito por Browne, Howard e Jolleys (1995) e Howard e Reed (1998), esta é determinada através da sobreposição de um sistema teste de pontos sobre a mesma área utilizada no disector, onde foram contados o total de pontos que tocaram os perfis neuronais $(\Sigma \mathrm{Pp})$ e também o total de pontos que tocaram a secção referência ( $\Sigma$ Pt) (Equação 6) (Figura 4). Este valor foi representado em porcentagem.

$$
\mathrm{V}_{\mathrm{v}}=\frac{\Sigma \mathrm{Pp}}{\Sigma \mathrm{Pt}}
$$

Equação 6

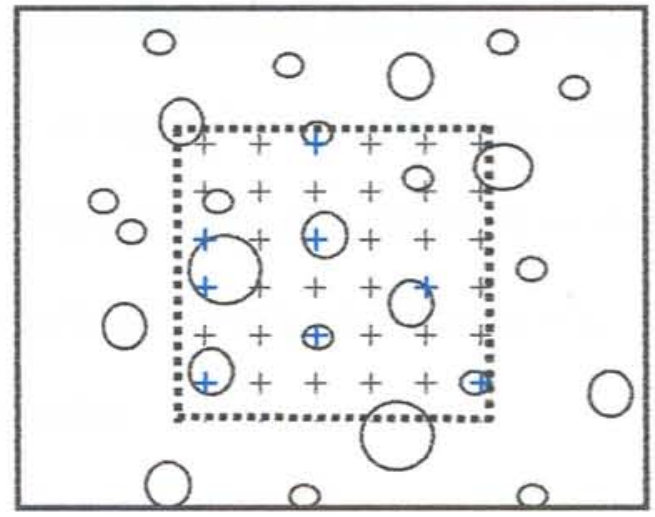

Figura 4 - Estimativa da densidade de volume neuronal. O mesmo campo observado na figura 1(A), mas com a sobreposição de um sistema teste de pontos, eqüidistantes entre si, foi utilizado para o cálculo da densidade de volume. A relação entre a somatória de pontos que tocam os perfis (representados no esquema pelos pontos azuis) (8 pontos), e a somatória de todos os pontos que estão na área testes da secção (36 pontos) constitui a densidade de volume. Desta forma, o Vv foi de $22 \%$ neste esquema. 


\subsubsection{ESTIMATIVA INDIRETA DO VOLUME NEURONAL MÉDIO (Vn)}

O tamanho médio das partículas neuronais pode ser estimado indiretamente através da combinação da densidade de volume e a densidade numérica (BROWNE; HOWARD; JOLLEYS, 1995; HOWARD; REED, 1998). Desta forma, o volume médio neuronal foi estimado através da divisão entre estas duas variáveis (Equação 7). O Vn foi expresso em $\mu \mathrm{m}^{3}$.

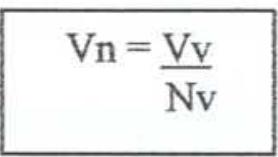

Equação 7

\subsubsection{ANALISE ESTATÍSTICA}

A análise estatística dos resultados foi realizada por meio do programa Statistical Analysis System (SAS, 1995). A análise da significância dos resultados morfométricos e estereológicos foi testada usando o procedimento PROC ANOVA para análises de variância e, em caso de detecção de efeitos significativos $(\mathrm{P}<0,05)$, utilizou-se o teste de Tukey para a comparação múltipla entre as médias dos diferentes grupos de análise.

As variáveis morfométricas (área seccional do neurônio, área seccional do núcleo e "form factor") foram correlacionadas entre si, por meio de correlações Momento-Produto de Pearson, da mesma forma que as variáveis estereológicas (N, Nv, Vref, Vv e Vn) associadas ao peso do animal. Os resultados da análise de correlação, quando apresentaram alta intensidade $\left(\mathrm{r}_{\mathrm{x}, \mathrm{y}}>0,7\right)$, foram submetidos posteriormente a análise de regressão. 
O modelo de regressão escolhido foi o linear, representado por uma equação do $1^{\circ}$ grau $\left(\mathrm{Y}=\mathrm{a}+\mathrm{b}_{\mathrm{x}, \mathrm{y}} \cdot \mathrm{X}\right)$. Neste estudo, a variável independente, isto é, a variável $\mathrm{X}$, foi representada pelo peso corpóreo dos cães, devido a fácil obtenção deste dado. A variável $\mathrm{Y}$, chamada de variável dependente, neste estudo foi N, Nv, Vref, Vv e Vn. Através da equação predita, pode-se plotar um gráfico para verificar como se comportam os valores da variável dependente $(\mathrm{Y})$ em função da variável independente $(\mathrm{X})$, onde "a" é a constante de regressão, representando o interceptor da reta com o eixo dos $\mathrm{x}, \mathrm{e}$ "bx,y" é o coeficiente de regressão, o qual representa a variação de $\mathrm{Y}$ para cada aumento unitário na variável $\mathrm{X}$. O coeficiente de determinação $\left(\mathrm{r}^{2}\right)$, no qual varia de zero a um, foi expresso em cada função, tendo os valores mais próximos a um indicando uma maior adequação da função em relação ao fenômeno observado. 


\section{RESULTADOS}

Os resultados oriundos dos três grupos etários (filhote, aduito e senil) sobre o gânglio mesentérico caudal (GMC) foram agrupados em itens para facilitar a compreensão dos mesmos. Desta forma, este capitulo foi subdividido em: anatomia macroscópica do GMC, anatomia microscópica do GMC, estudo morfométrico e estudo estereológico.

\subsection{ANATOMIA MACROSCÓPICA DO GMC}

O GMC nos cães nos diferentes grupos etários estudados foi encontrado envolvendo a artéria mesentérica caudal na sua emergência junto à aorta abdominal, sendo sua porção dorsal conectada ao tronco simpático via nervos esplâncnicos lombares e sua porção cranial com o gânglio celíaco-mesentérico via nervos intermesentéricos. Três nervos partiam do GMC, o primeiro caminhava junto com a artéria mesentérica caudal, sendo denominado de nervo hipogástrico principal, no qual se dirigia para o cólon. Os outros dois nervos adentravam a cavidade pélvica e se dirigiam aos gânglios pélvicos, sendo denominados de nervos hipogástricos direito e esquerdo. Ainda, o nervo hipogástrico principal se dividia em dois ramos, um seguia cranialmente, denominado de nervo colônico esquerdo, e outro seguia caudalmente, denominado nervo retal cranial (Figura 5 A-B).

Macroscopicamente, o GMC foi visto como uma massa ganglionar única em todos os grupos etários, variando seu tamanho nos filhotes de 6,0 a 7,0 mm (média $6,7 \mathrm{~mm}$; desvio 
padrão 0,06 ), nos adultos o tamanho encontrado foi o mesmo para todas as amostras, isto é,

$12 \mathrm{~mm}$ e nos senis o tamanho variou de 10 a $16 \mathrm{~mm}$ (média $12,3 \mathrm{~mm}$; desvio padrão 0,32 ).
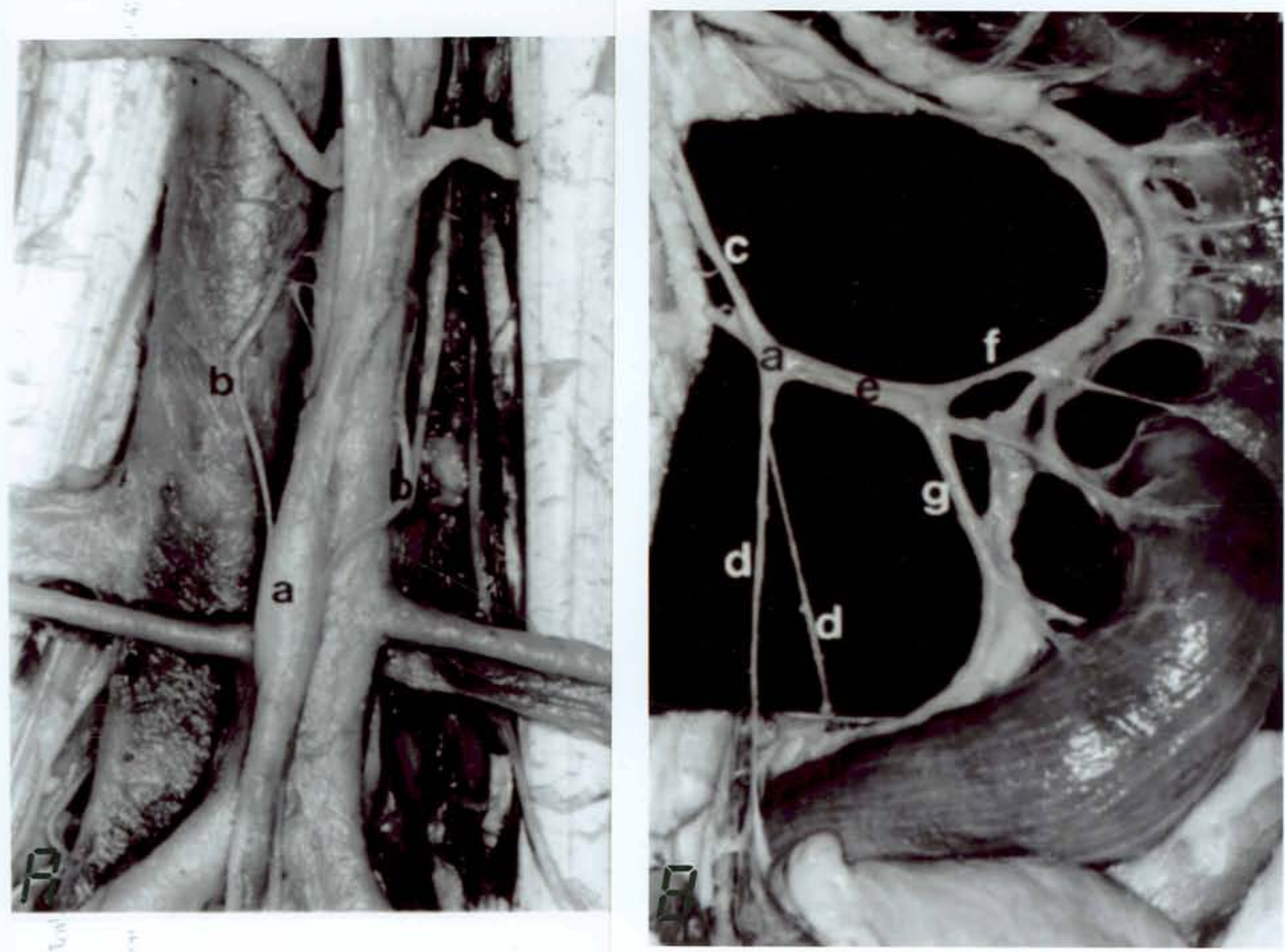

Figura 5 (A-B) - Macroestrutura do gânglio mesentérico caudal de cães e suas conexões (vista caudal). Em (a) gânglio mesentérico caudal; (b) nervos esplâncnicos lombares (c) nervos intermesentéricos; (d) nervos hipogástricos (direito e esquerdo); (e) nervo hipogástrico principal; (f) nervo colônico esquerdo; (g) nervo retal cranial

\subsection{ANATOMIA MICROSCOPICA DO GMC}

As características microestruturais do GMC diferem entre os grupos etários estudados.

No grupo I, representado pelos filhotes, o GMC estava constituído por massas ganglionares

(ou lobos ganglionares) envolvidas individualmente por uma cápsula de tecido conjuntivo, 
sendo estas massas conectadas uma às outras por um tecido conjuntivo (Figura 6). Foram evidenciados de dois a quatro lobos ganglionares nos filhotes, delimitados por cápsulas distintas, sendo estes não vistos macroscopicamente.

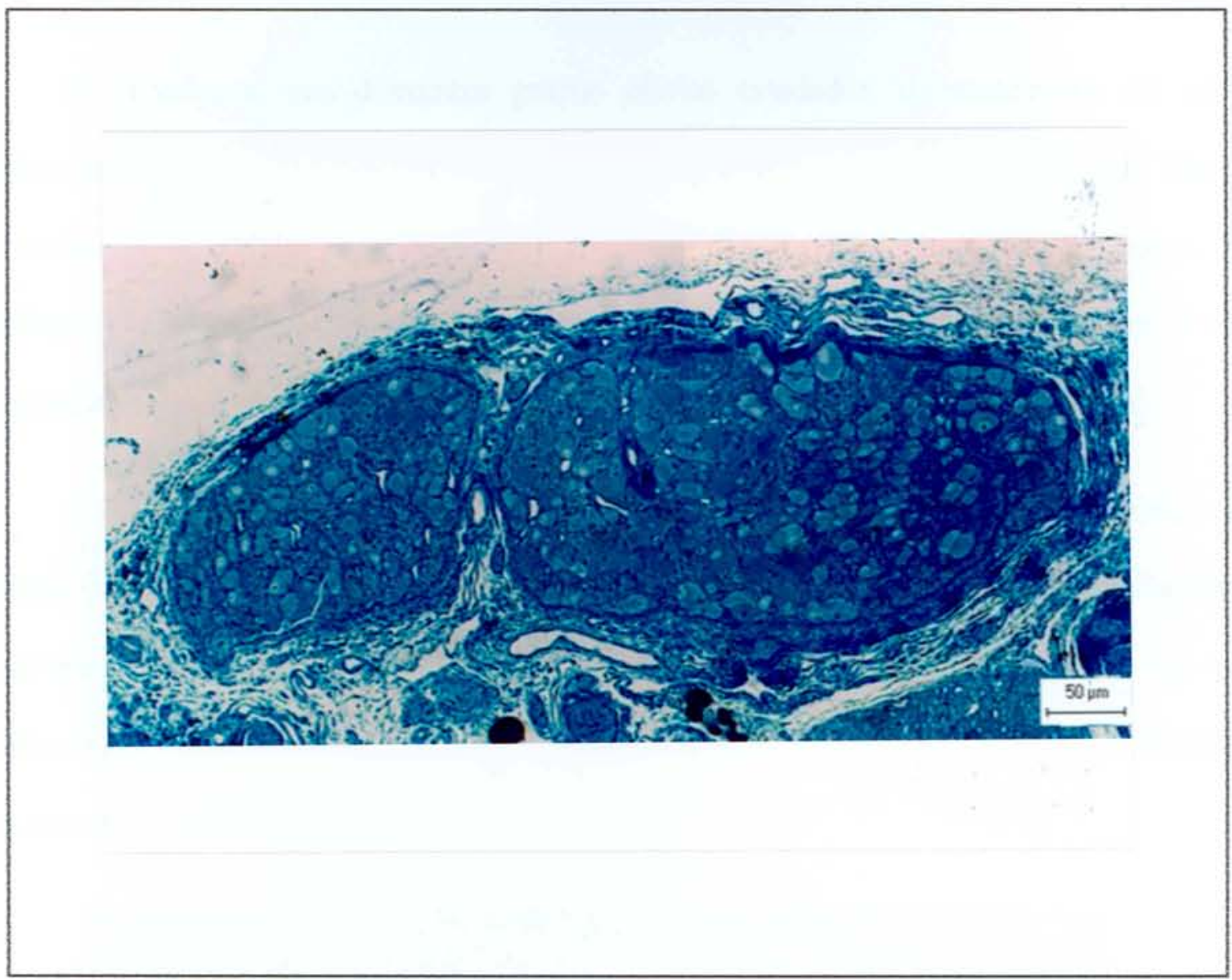

Figura 6-Massas ganglionares (ou lobos ganglionares) encontrados nos filhotes

Nos grupos II e III, representados pelos aduitos e senis, respectivamente, o GMC era representado por uma massa ganglionar única envolvida por uma cápsula conjuntiva ricamente vascularizada. Esta massa ganglionar era dividida internamente em unidades ganglionares distintas e separadas por septos de tecido conjuntivo proveniente da cápsula, que delimitavam grupos celulares distintos no interior do gânglio. Em função do arranjo característico em unidades ganglionares, o GMC foi denominado de complexo ganglionar que constituiu o arranjo citoarquitetural tipico para os animais adultos e senis. 
O GMC em todos os grupos etários era constituido principalmente por três elementos celulares, os neurônios ganglionares, as células da glia (onde apenas os seus respectivos núcleos foram evidenciados) e as células SIF (Figura 7 A-C). Fibroblastos também foram observados compondo a microestrutura do GMC.

Os neurônios, nos diferentes grupos etários estudados, demonstraram um perfil eliptico, confirmado pelos resultados obtidos através da distribuição do "form factor" (dados apresentados posteriormente) e um núcleo deslocado perifericamente. Nos filhotes, foi verificado a existência de um a dois nucléolo no interior do núcleo (Figura 7 C), diferentemente dos cães adultos e senis, onde foi verificado apenas a existência de um.

A presença de neurônios binucleados foi verificada, mas somente nos filhotes e em pequena proporção, representando apenas $3 \%$. Alterações ligadas ao envelhecimento também foram verificadas, onde os neurônios provenientes do grupo senil apresentaram em seu citoplasma grânulos de lipofucsina (Figura 7 A-B), pigmento este encontrado freqüentemente com o aumento da idade.

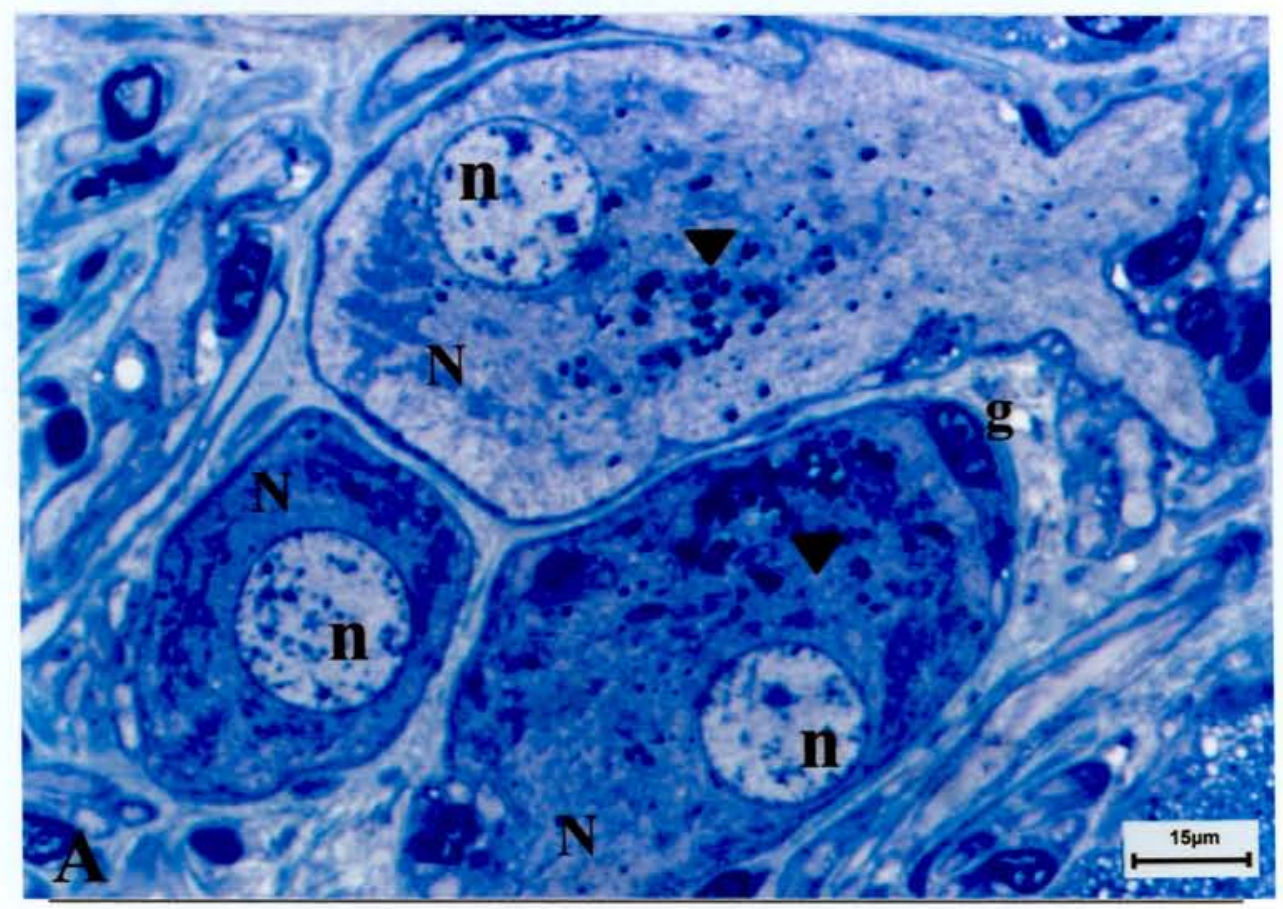



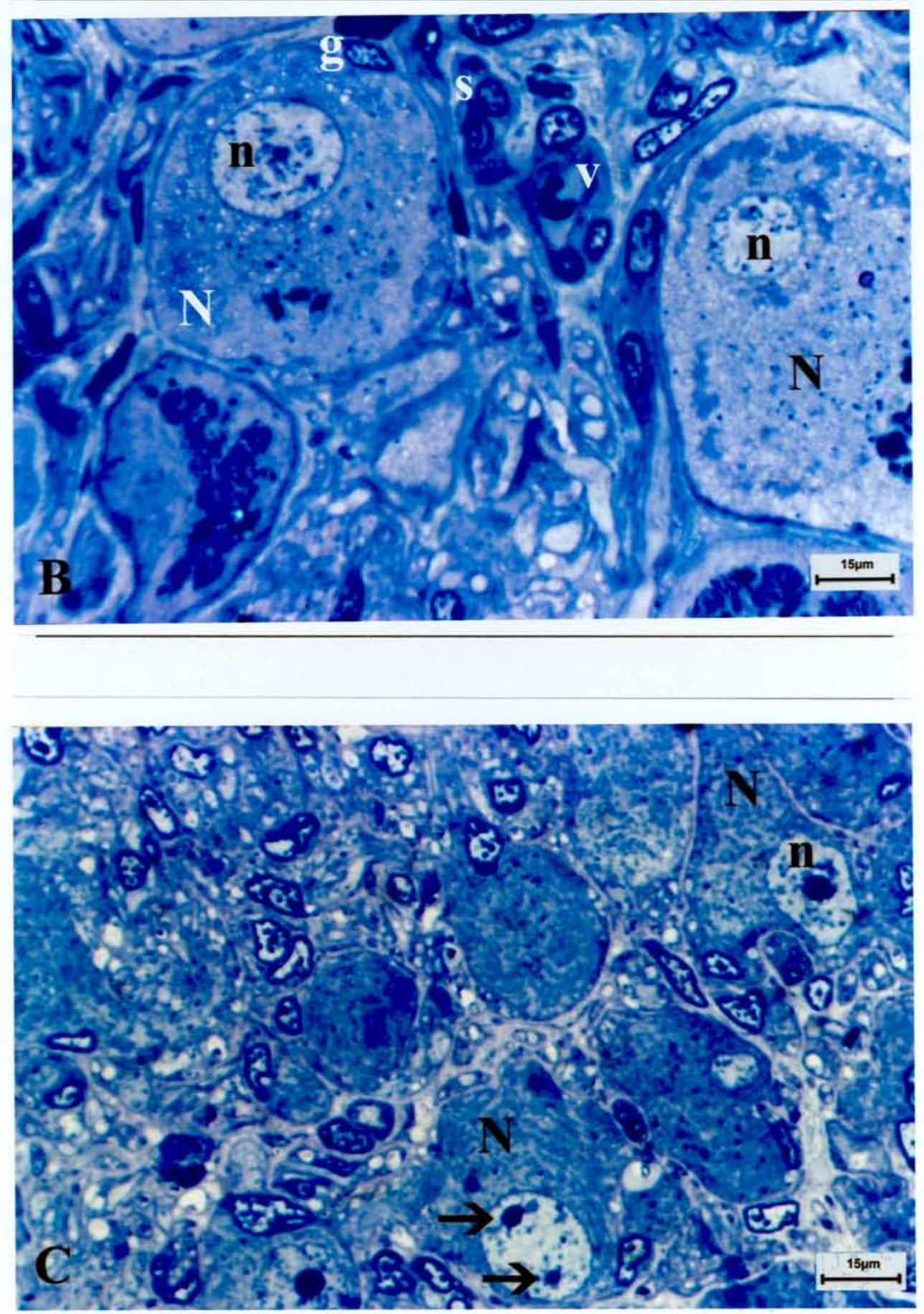

Figura 7 (A-C) - Microestrutura do gânglio mesentérico caudal. A-B e C: cães senil e filhote, respectivamente, demonstrando os neurônios $(\mathrm{N})$, núcleo (n), nucléolo $(\rightarrow)$ ), núcleos das células da glia $(\mathrm{g})$, células SIF (s), grânulos de lipofucsina $(>)$ e capilar (v) 
A quantidade de tecido não neuronal nos filhotes era inferior a dos adultos e senis, como confirmados pelos resultados da densidade de volume, onde foi verificado que nos filhotes aproximadamente $64 \%$ do volume do GMC era representado por tecido não neuronal e nos adultos e senis aproximadamente $71 \%$. Desta forma, os neurônios nos filhotes estavam mais aglomerados do que nos demais grupos, onde estes estavam mais afastados uns dos outros (Figura $8 \mathrm{~A}-\mathrm{C}$ ).
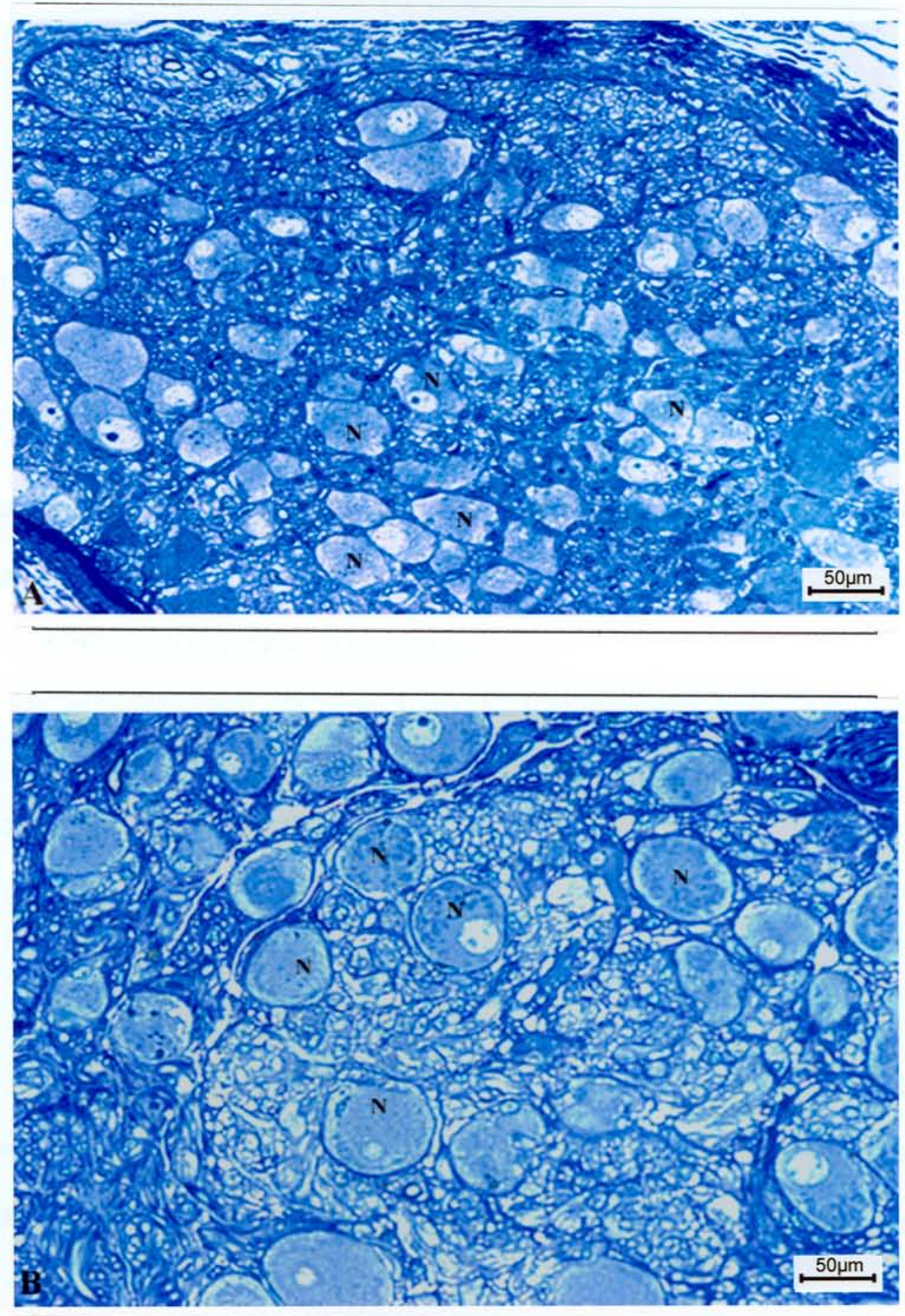


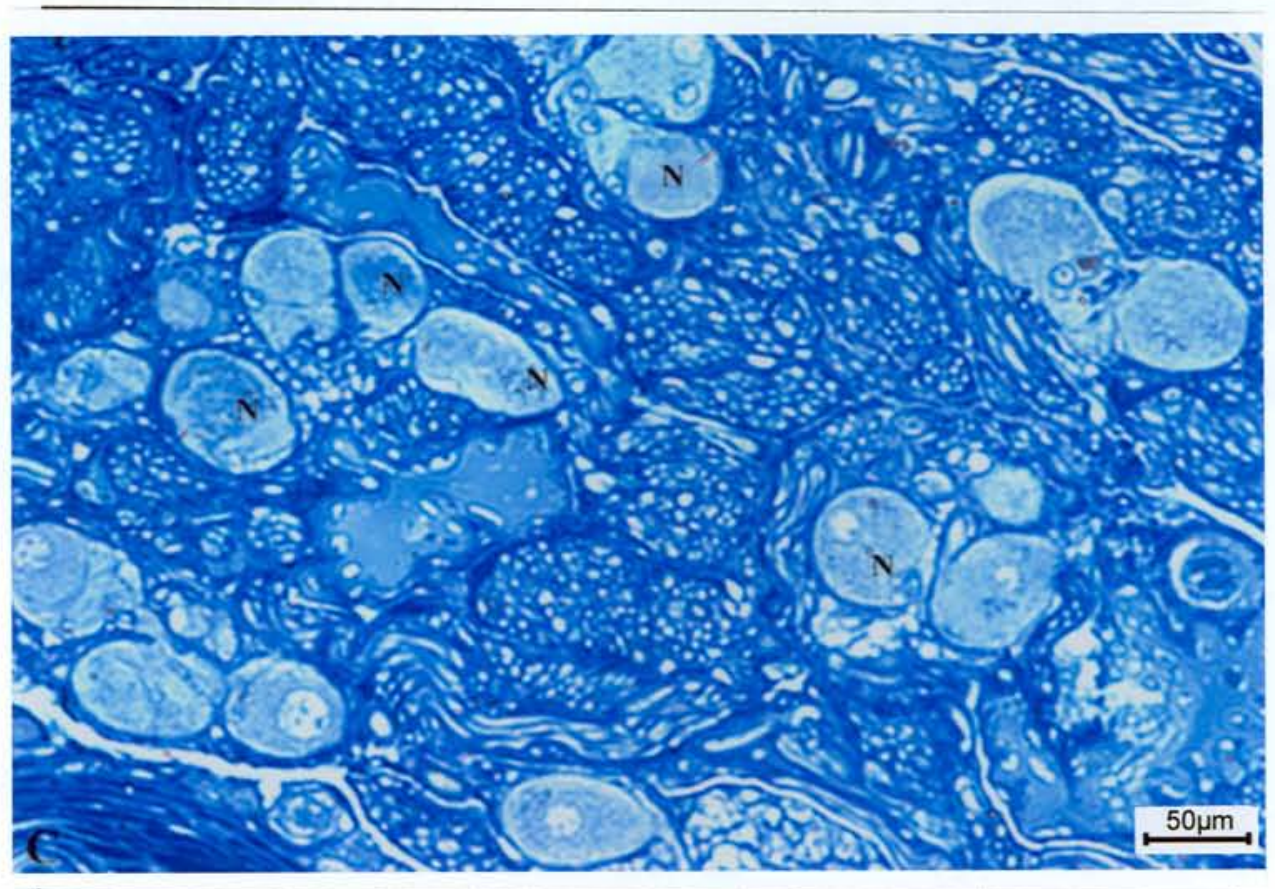

Figura 8 (A-C) - Microestrutura dos três diferentes grupos etários. A: filhote; B: adulto; C: senil. (N) neurônio

Cada perfil neuronal apresentava-se envoltos por um a três núcleos de célula da glia. Próximo aos neurônios foi verificado a existência de células SIF, sendo estas também encontradas em grupos junto a capilares. Os capilares foram encontrados espalhados pelo o gânglio, no interior das unidades ganglionares.

\subsection{ESTUDO MORFOMÉTRICO}

A análise morfométrica dos neurônios encontrados no GMC de cães nos diferentes grupos etários (filhotes, adultos e senis) teve como objetivo fornecer dados sobre o tamanho do neurônio e do núcleo, ambos expressos através de suas áreas seccionais, a relação núcleocitoplasma e o estudo da distribuição quantitativa da forma do perfil neuronal ("form factor"). 
A área seccional do neurônio, verificada em 162 neurônios, variou no grupo I de $125,5-895 \mu \mathrm{m}^{2}$ (média $435 \mu \mathrm{m}^{2}$; desvio padrão 117,03 ), no grupo II de $123-1966,5 \mu \mathrm{m}^{2}$ (média $980,23 \mu \mathrm{m}^{2}$; desvio padrão 359,46 ) e no grupo III de $136,5-3539,3 \mu \mathrm{m}^{2}$ (média $1185,8 \mu^{2}$; desvio padrão 569,80 ). No grupo I, $41 \%$ dos neurônios apresentaram um tamanho entre $400-600 \mu \mathrm{m}^{2}$ e no grupo II e III, $24 \%$ e $22 \%$ dos neurônios, respectivamente, entre $800-1000 \mu \mathrm{m}^{2}$ (Figura 9).

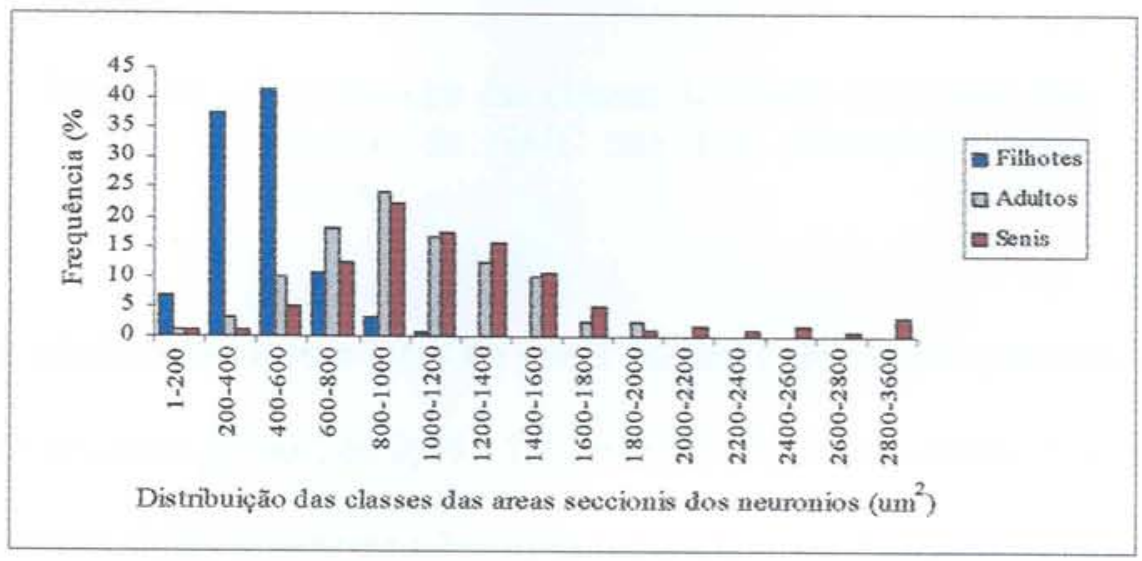

Figura 9 - Distribuição das classes das áreas seccionais dos neurônios do GMC nos três diferentes grupos etários

A área seccional do núcleo, verificada em 99 neurônios, variou no grupo I de 63,47 $198,26 \mu \mathrm{m}^{2}$ (média $115,20 \mu \mathrm{m}^{2}$; desvio padrão 24,67 ), no grupo II de $71,56-297,76 \mu \mathrm{m}^{2}$ (média $179,56 \mu \mathrm{m}^{2}$; desvio padrão 41,28 ) e no grupo III de $49,72-417,85 \mu \mathrm{m}^{2}$ (média 187,26 $\mu \mathrm{m}^{2}$; desvio padrão 70,66). No grupo I, $64 \%$ dos núcleos apresentaram um tamanho entre 100 - $150 \mu \mathrm{m}^{2}$ e no grupo II e $\mathrm{III}, 48,5 \%$ e $42,5 \%$, respectivamente, entre $150-200 \mu \mathrm{m}^{2}$ (Figura $10)$. 


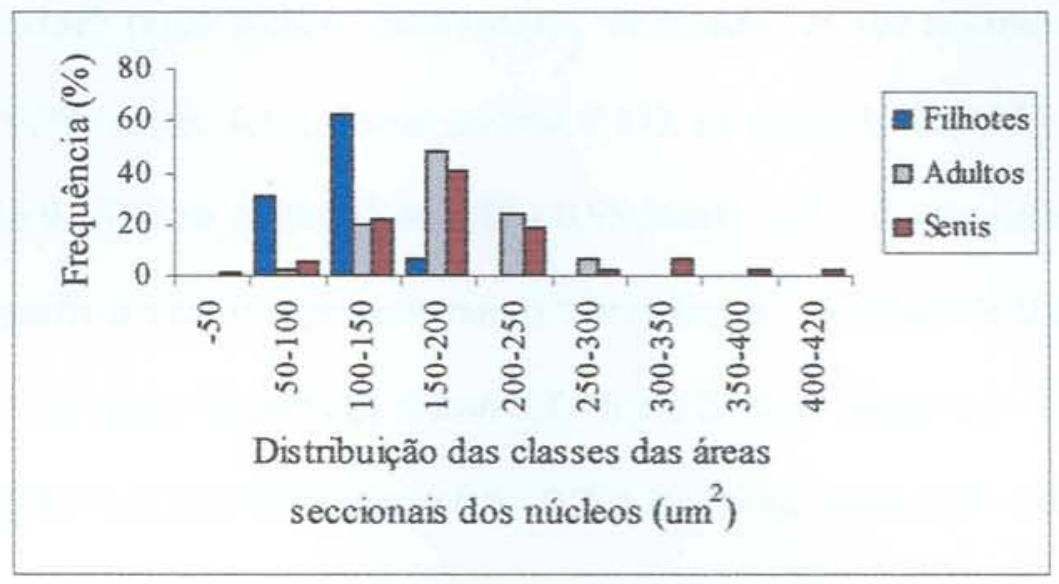

Figura 10 - Distribuição das classes das áreas seccionais dos núcleos do GMC nos três diferentes grupos etários

A relação núcleo-citoplasma (área do perfil nuclear / área do citoplasma), verificada em 99 neurônios, variou no grupo I de 0,14 - 1,5 (média 0,41; desvio padrão 0,22 ), no grupo II de 0,11 - 1,9 (média 0,23; desvio padrão 0,18) e no grupo III de 0,04 - 0,66 (média 0,2; desvio padrão 0,08). No grupo I, $28,3 \%$ dos neurônios apresentaram a relação núcleocitoplasma na classe de $0,20-0,29$ e $27,3 \%$ na classe $0,30-0,39$. No grupo II, $49 \%$ na classe $0,20-0,29$ e $42 \%$ na classe $0,10-0,19$. No grupo III, $56 \%$ na classe $0,10-0,19$ (Figura 11 ).

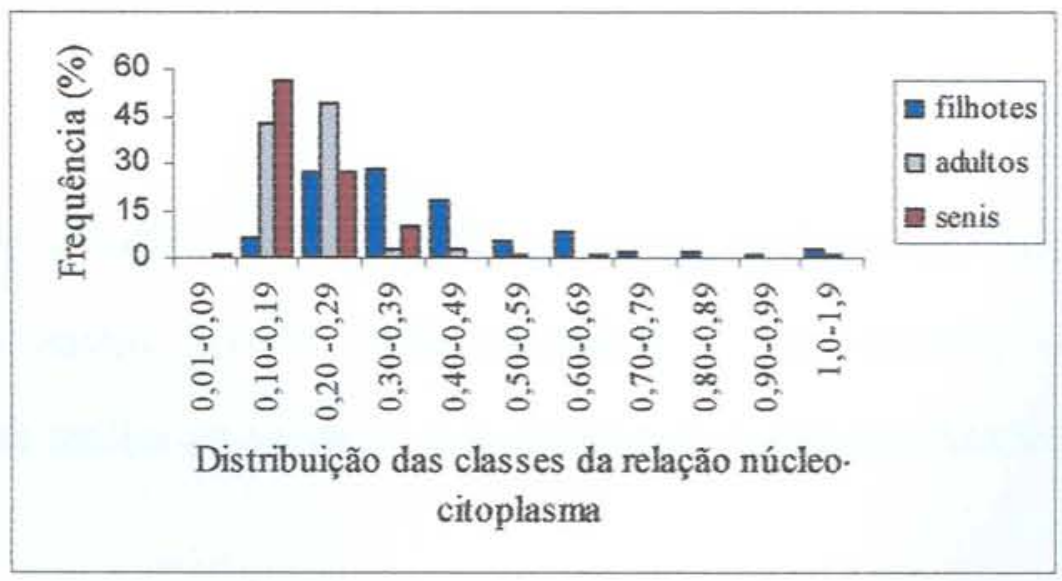

Figura 11 - Distribuição das classes da relação entre núcleocitoplasma nos três diferentes grupos etários 
O "form factor" (eixo menor / eixo maior), verificado em 162 neurônios, variou no grupo I de 0,30 - 0,99 (média 0,69; desvio padrão 0,13), no grupo II de 0,33 - 0,99 (média 0,74 ; desvio padrão 0,13 ) e no grupo III de 0,35 - 0,99 (média 0,73 ; desvio padrão 0,14 ). No grupo I, $27 \%$ dos perfis neuronais apresentaram o "form-factor" na classe de $0,6-0,7$ e $25 \%$ na classe $0,7-0,8$. No grupo II, $29 \%$ na classe $0,7-0,8$ e $24 \%$ na classe $0,8-0,9$. No grupo III, $25,9 \%$ na classe $0,7-0,8,20,9 \%$ na classe $0,6-0,7$, e $19,7 \%$ na classe $0,8-0,9$ (Figura 12 ).

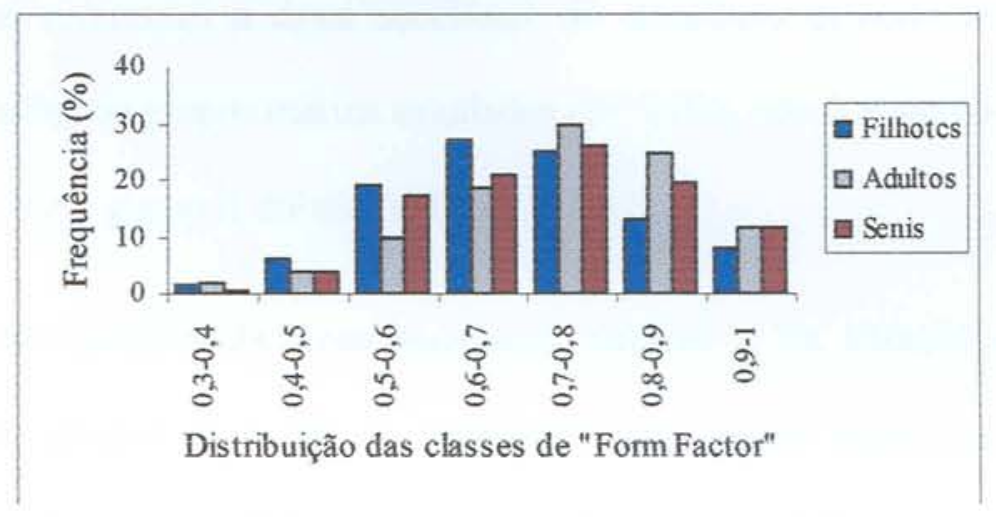

Figura 12 - Distribuição das classes de "Form Factor" nos três diferentes grupos etários

\subsubsection{ANÁLISE ESTATÍSTICA}

No tocante a análise estatística para as variáveis morfométricas (área seccional do neurônio e do núcleo, relação núcleo-citoplasma e "form-factor"), optou-se pelos procedimentos de análise de variância e as análises de correlações Momento-Produto de Pearson. 


\subsubsection{ANÁLISE DE VARIÂNCIA (ANOVA)}

O procedimento ANOVA aplicado nos parâmetros morfométricos teve por objetivo detectar possíveis diferenças entre os grupos etários (filhotes, adultos e senis) e ainda constatar significância ou não destas diferenças. Os resultados foram sumarizados na tabela 1 .

Os resultados referentes a área seccional do neurônio demonstraram diferenças significativas entre todos os grupos etários estudados $(\mathrm{P}<0,01)$, isto é, o grupo I diferiu do II, o grupo I diferiu do III e o grupo II diferiu do III.

$\mathrm{Na}$ análise comparativa da área seccional nuclear e da relação entre núcleocitoplasma entre os grupos II e III os resultados não foram significativos $(\mathrm{P}>0,05)$. Entretanto, os resultados destas duas variáveis morfométricas diferem significativamente $(\mathrm{P}<0,01)$ quando comparado o grupo I aos demais grupos, isto é, o grupo I com o II e o grupo I com o III.

Em relação ao "form-factor", os resultados entre os grupos 111 e 1 e 11 e $I I I$ não demonstraram diferenças significativas $(\mathrm{P}>0,05)$. Contudo, foram encontradas diferenças significativas entre os grupos I e II $(\mathrm{P}<0,01)$.

Tabela 1 - Médias das variáveis morfométricas nos três diferentes grupos etários.

\begin{tabular}{ccccc}
\hline & \multicolumn{4}{c}{ MÉDIAS } \\
\cline { 2 - 5 } GRUPOS & $\begin{array}{c}\text { Área neuronal } \\
\text { seccional }\left(\mu \mathrm{m}^{2}\right)\end{array}$ & $\begin{array}{c}\text { Área nuclear } \\
\text { seccional }\left(\mu \mathrm{m}^{2}\right)\end{array}$ & $\begin{array}{c}\text { Relacão núcleo- } \\
\text { citoplasma }\end{array}$ & "Form-factor" \\
I (filhotes) & $435 \mathrm{a}^{1}$ & $115,2 \mathrm{a}$ & $0,41 \mathrm{a}$ & $0.69 \mathrm{a}$ \\
II (adultos) & $980,23 \mathrm{~b}$ & $179,56 \mathrm{~b}$ & $0,23 \mathrm{~b}$ & $0,74 \mathrm{~b}$ \\
III (senis) & $1185,8 \mathrm{c}$ & $187,26 \mathrm{~b}$ & $0,2 \mathrm{~b}$ & $0,73 \mathrm{ab}$ \\
\hline
\end{tabular}

${ }^{3}$ Médias seguidas por letras diferentes na mesma coluna diferem pelo método de Tukey $(\mathrm{P}<0,01)$. 


\subsubsection{ANÁLISE DE CORRELAÇÃO}

As análises de correlações Momento-Produto de Pearson tiveram como o objetivo identificar possíveis associações entre as variáveis morfométricas (área seccional do neurônio e do núcleo e o "form factor") dentro de cada grupo etário.

Em relação as variáveis área seccional do neurônio e o "form-factor", não foi encontrada correlação em nenhum grupo.

Foi verificado correlação positiva entre as variáveis área seccional do neurônio e a área seccional do núcleo no grupo I $(r=0,43)$, no grupo II $(r=0,64)$ e no grupo III $(r=$ $0,74)$.

\subsection{ESTUDO ESTEREOLÓGICOS}

O estudo estereológico teve como objetivo verificar possíveis alterações de parâmetros tais como número total de neurônios, quantidade de neurônios por unidade de volume (densidade numérica), o volume do gânglio, a proporção de volume ocupada pelos neurônios no volume total do gânglio e o volume neuronal médio, durante períodos bem definidos do desenvolvimento, mais precisamente durante maturação e envelhecimento.

$\mathrm{O}$ número total de neurônios $(\mathbf{N})$, estimado através do método disector físico em combinação com o método de Cavalieri variou no grupo I de 55.448,3 a 81.677,4 (média 70.140,01; desvio padrão $13.396,0$; coeficiente de variação 0,19 ), no grupo II de 975.000 a 1.243 .421 (média 1.110.307,02; desvio padrão 134.224; coeficiente de variação 0,12 ) e no 
grupo III de 1.026.467,7 a 1.452.534,1 (média 1.204.515,65; desvio padrão 221.483,8; coeficiente de variação 0,18$)$.

A densidade numérica (Nv), quantidade de neurônios por unidade de volume (neste trabalho: $\mathrm{mm}^{3}$ ), no grupo I variou de $29.142,8$ a $32.258,1$ (média $29.911,42$; desvio padrão 2.072,17; coeficiente de variação 0,07), no grupo II de 12.500 a 13.157,8 (média 12.719,27; desvio padrão 379,78; coeficiente de variação 0,03) e nos senis de 10.978,3 a 11.818,2 (média 11.500,33; desvio padrão 455,68; coeficiente de variação 0,04 ).

No grupo I foram aplicados 31, 35 e 36 disectors para quantificar 100, 102 e 102 neurônios, analisando assim um volume de $0,0031 \mathrm{~mm}^{3} ; 0,0035 \mathrm{~mm}^{3}$ e $0,0036 \mathrm{~mm}^{3}$, respectivamente. No grupo II foram aplicados 19,20 e 22 disectors para quantificar 100,100 e 110 neurônios, analisando assim um volume de $0,0076 \mathrm{~mm}^{3} ; 0,008 \mathrm{~mm}^{3}$ e $0,0088 \mathrm{~mm}^{3}$, respectivamente. No grupo III foram utilizados 22,22 e 23 disectors para quantificar 103 , 104 e 101 neurônios, analisando assim um volume de $0,0088 \mathrm{~mm}^{3} ; 0,0088 \mathrm{~mm}^{3}$ e $0,0092 \mathrm{~mm}^{3}$, respectivamente.

O volume ganglionar (ou volume do espaço referência) (Vref) no grupo I variou de 1,9 a $2,5 \mathrm{~mm}^{3}$ (média 2,33 $\mathrm{mm}^{3}$; desvio padrão 0,33 ; coeficiente de variação 0,14 ), no grupo II de 78 a $94,5 \mathrm{~mm}^{3}$ (média $87,16 \mathrm{~mm}^{3}$; desvio padrão 8,40 ; coeficiente de variação 0,09 ) e no grupo III de 93,5 a $124 \mathrm{~mm}^{3}$ (média 104,5 $\mathrm{mm}^{3}$; desvio padrão 16,93; coeficiente de variação 0,16 ). O coeficiente de erro (CE) para a estimativa do volume ganglionar foi de $1,8 \%, 2 \%$ e $3 \%$ (grupo I), $5,3 \%, 7,6 \%, 7,6 \%$ (grupo II) e $7 \%, 10 \%$ e $13 \%$ (grupo III).

A densidade de volume (Vv), isto é, a proporção de volume ocupada pelos neurônios em relação ao volume total do GMC, variou no grupo I de 32,5 a $39 \%$ (média $35,30 \%$; desvio padrão 0,03 ; coeficiente de variação 0,095 ), no grupo II de 27,1 a $31,8 \%$ 
(média 29,10\%; desvio padrão 0,02; coeficiente de variação 0,083 ) e no grupo III de 28,8 a $30,6 \%$ (média 29,43\%; desvio padrão 0,01 ; coeficiente de variação 0,034 ).

O volume neuronal médio (Vn), obtido indiretamente através da relação entre a densidade de volume e a densidade numérica, no grupo I variou de $11.165,7$ a $12.130,6 \mu \mathrm{m}^{3}$ (média $11.800 \mu \mathrm{m}^{3}$; desvio padrão 519,6 ; coeficiente de variação 0,044 ), no grupo II de 21.680 a $24.183,4 \mu \mathrm{m}^{3}$ (média $22.866,7 \mu \mathrm{m}^{3}$; desvio padrão de125,8; coeficiente de variação 0,055 ) e no grupo III de $24.487,7$ a $26.261 \mu \mathrm{m}^{3}$ (média $25.666,7 \mu \mathrm{m}^{3}$; desvio padrão 101,2 ; coeficiente de variação 0,039 ).

Os resultados apresentados, tais como peso corpóreo, número total de neurônios, densidade numérica, número de disectors aplicados, número de neurônios contados/disector, volume ganglionar (ou volume do espaço referência), densidade de volume e volume neuronal médio foram apresentados sistematicamente na tabela 2. 
Tabela 2 - Inter-relação das variáveis peso corpóreo, número total de neurônios, densidade numérica, número de neurônios contados por disector, quantidade de disectors aplicados, volume ganglionar, densidade de volume neuronal e o volume neuronal médio no GMC de cães nos três diferentes grupos etários

\begin{tabular}{|c|c|c|c|c|c|c|c|c|c|}
\hline Grupo & Idade & Peso (Kg) & $\begin{array}{c}\text { Densidade } \\
\text { numérica } \\
\text { (neuronios/ } \\
\mathrm{mm}^{3} \text { ) }\end{array}$ & $\begin{array}{l}\text { Número de } \\
\text { neurônios } \\
\text { contados }\end{array}$ & $\begin{array}{l}\text { Quantidade } \\
\text { de disectors } \\
\text { aplicados }\end{array}$ & $\begin{array}{c}\text { Volume } \\
\text { ganglionar } \\
\left(\mathrm{mm}^{3}\right)\end{array}$ & $\begin{array}{c}\text { Número } \\
\text { total de } \\
\text { neurônios }\end{array}$ & $\begin{array}{c}\text { Densidade } \\
\text { de volume } \\
(\%)\end{array}$ & $\begin{array}{c}\text { Volume } \\
\text { médio } \\
\text { neuronal } \\
\left(\mu \mathrm{m}^{3}\right)\end{array}$ \\
\hline \multirow{3}{*}{$\begin{array}{c}\mathrm{I} \\
\text { (filhotes) }\end{array}$} & 2 meses & 0,15 & $29.142,80$ & 102 & 35 & 2,5 & $73.294,3$ & 32,50 & $11.165,7$ \\
\hline & 2 meses & 0,18 & $28.333,30$ & 102 & 36 & 1,9 & $55.448,3$ & 34,40 & $12.130,6$ \\
\hline & 2 meses & 0,18 & $32.258,10$ & 100 & 31 & 2,5 & $81.677,4$ & 39,00 & $12.093,1$ \\
\hline Média & & 0,17 & $29.911,42$ & & & 2,3 & $70.140,01$ & 35,30 & 11.800 \\
\hline \multirow{3}{*}{$\begin{array}{c}\text { II } \\
\text { (adultos) }\end{array}$} & 1 ano & 18 & 12.500 & 100 & 20 & 89 & 1.112 .500 & 28,40 & 22.720 \\
\hline & 2 anos & 15 & $13.157,80$ & 100 & 19 & 94,5 & 1.243 .421 & 31,80 & $24.183,4$ \\
\hline & 2 anos & 13 & 12.500 & 110 & 22 & 78 & 975.000 & 27,10 & 21.680 \\
\hline \multirow[t]{2}{*}{ Média } & & 15,3 & $12.719,27$ & & & 87,2 & $1.110 .307,02$ & 29,10 & $22.866,7$ \\
\hline & 5 anos & 20 & $10.978,3$ & 104 & 22 & 93,5 & $1.026 .467,40$ & 28,80 & 26.261 \\
\hline \multirow{2}{*}{$\begin{array}{c}\text { III } \\
\text { (senis) }\end{array}$} & 10 anos & 17 & $11.818,2$ & 103 & 22 & 96 & $1.134 .545,40$ & 28,90 & $24.487,7$ \\
\hline & 7 anos & 23 & $11.704,55$ & 101 & 23 & 124 & $1.452 .534,10$ & 30,60 & $26.152,2$ \\
\hline Média & & 20 & $11.500,33$ & & & 104,5 & 1204515,65 & 29,40 & $25.666,7$ \\
\hline
\end{tabular}




\subsubsection{ANÁLISE ESTATÍSTICA}

No que concerne a análise estatística para as variáveis estereológicas $(\mathrm{N}, \mathrm{Nv}, \mathrm{Vref}, \mathrm{Vv}$ e Vn), optou-se pelos procedimentos de análise de variância, análises de correlações Momento-Produto de Pearson e análise de regressão linear.

\subsubsection{ANÁLISE DE VARIÂNCIA (ANOVA)}

O procedimento ANOVA aplicado nos parâmetros estereológicos teve por objetivo detectar ou não possíveis diferenças significativas entre os diferentes grupos etários, tendo seus resultados apresentados sistematicamente na tabela 3.

A análise de variância demonstrou que o grupo I apresenta diferenças significativas no tocante ao número total de neurônios, a densidade numérica, o volume do ganglionar e a densidade de volume quando comparado aos demais grupos $(\mathrm{P}<0,01)$. Entretanto, nenhuma diferença significativa foi observada para os mesmos parâmetros entre os grupos $\mathrm{H}$ e $I I I$ $(\mathrm{P}>0,05)$

Os resultados referentes ao volume neuronal médio diferem significativamente entre todos os grupos ( $\mathrm{P}<0,01)$, isto é, o grupo 1 difere do $\mathrm{Il}$, o grupo I difere do Ill e o grupo II difere do III. 
Tabela 3 - Média das variáveis estereológicas nos três diferentes grupos etários.

\begin{tabular}{lccccc}
\hline & \multicolumn{5}{c}{ MÉDIAS } \\
\cline { 2 - 6 } GRUPOS & $\begin{array}{c}\text { Número total de } \\
\text { neurônios (N) }\end{array}$ & $\begin{array}{c}\text { Densidade } \\
\text { numérica (Nv) }\end{array}$ & $\begin{array}{c}\text { Volume } \\
\text { ganglionar } \\
\text { (Vref) }\end{array}$ & $\begin{array}{c}\text { Densidade de } \\
\text { Volume (Vv) }\end{array}$ & $\begin{array}{c}\text { Volume } \\
\text { neuronal médio } \\
\text { (Vn) }\end{array}$ \\
I (filhotes) & $70.140 \mathrm{a}^{1}$ & $29.911 \mathrm{a}$ & $2,3 \mathrm{a}$ & $35,3 \% \mathrm{a}$ & $11.800 \mathrm{a}$ \\
II (adultos) & $1.110 .307 \mathrm{~b}$ & $12.719 \mathrm{~b}$ & $87,2 \mathrm{~b}$ & $29,4 \% \mathrm{~b}$ & $22.866,7 \mathrm{~b}$ \\
III (senis) & $1.204 .516 \mathrm{~b}$ & $11.500 \mathrm{~b}$ & $104,5 \mathrm{~b}$ & $29,1 \% \mathrm{ab}$ & $24.487,7 \mathrm{c}$ \\
\hline
\end{tabular}

${ }^{i}$ Médias seguidas por letras diferentes na mesma coluna diferem pelo método de Tukey $(\mathrm{P}<0,01)$.

\subsubsection{ANÁLISE DE CORRELAÇ̃̃O}

A análise de correlação Momento-Produto de Pearson entre as variáveis estereológicas (N, Nv, Vref, Vv e Vn) e o peso corpóreo dos cães nos diferentes grupos etários foi efetuada com a finalidade de identificar ou não possiveis associações entre eles.

A variável ou parâmetro peso corpóreo apresentou uma correlação positiva com as variáveis número total de neurônios $(r=0,97)$, volume ganglionar $(r=0,99)$ e com o volume neuronal médio $(\mathrm{r}=0,98)$. Paradoxalmente, no atinente ao peso corpóreo uma correlação negativa foi verificada em relação as variáveis densidade numérica $(r=0,96)$ e densidade de volume $(\mathrm{r}=0,74)$.

A variável volume ganglionar apresentou uma correlação positiva com o número total de neurônios $(r=0,99)$ e o volume neuronal médio $(r=0,98)$. Por outro lado a mesma variável (volume ganglionar) apresentou uma correlação negativa com a densidade numérica $(\mathrm{r}=0,96)$ e com a densidade de volume $(\mathrm{r}=0,73)$. 
A variável densidade numérica apresentou uma correlação negativa com o número total de neurônios $(\mathrm{r}=0,96)$.

\subsubsection{ANÁLISE DE REGRESSÃO LINEAR}

Sendo o peso corpóreo uma variável de fácil acesso e os resultados de correlação entre o peso corpóreo e as variáveis estereológicas (N, Nv, Vref, Vv e Vn) terem apresentado alta intensidade, $r_{x, y}>0,7$, foi possível realizar a análise de regressão linear. Desta forma, as equações do $1^{\circ}$ grau $\left(Y=a+b_{x, y} \cdot X\right)$ obtidas em função do peso para as variáveis estereológicas, anteriormente relatadas, fornecem dados muito próximos aos valores reais observados nesta pesquisa, sendo isto comprovado pelos altos coeficientes de determinação $\left(\mathrm{r}^{2}\right)$, que foram 0,93 para o número total de neurônios $(\mathrm{N}), 0,91$ para a densidade numérica (Nv), 0,97 para o volume referencia (Vref) e 0,96 para o neuronal médio (Vn). As equações para as variáveis estereológicas estão apresentadas abaixo, onde, por exemplo, na primeira equação expressa, para o cálculo do número total de neurônios $(\mathrm{N})$, o interceptor da reta com o eixo dos $\mathrm{x}$, isto é, a constante de regressão, é representada pelo valor de 95.401 e o coeficiente de regressão pelo valor de 59.114 .

$$
\begin{gathered}
\mathbf{N}=95.401+(59.114 \times \mathrm{Kg}) \\
\mathbf{N} \mathbf{v}=29.115+(-935,47518 \times \mathrm{Kg}) \\
\mathbf{V r e f}=3,34051+(5,18204 \times \mathrm{Kg}) \\
\mathbf{V n}=12.003+(683,92195 \times \mathrm{Kg})
\end{gathered}
$$


A partir das equações acima referidas, foi possivel elaborar gráficos demonstrando o comportamento de uma variável ou parâmetro estereológico específico em função do peso corpóreo (Figura 13 A-D). Nestes gráficos, fizemos a diferenciação entre os valores realmente observados na amostra ( $\left.{ }^{(}\right)$e os valores estimados por meio das equações supracitadas $(\boldsymbol{\Lambda})$.
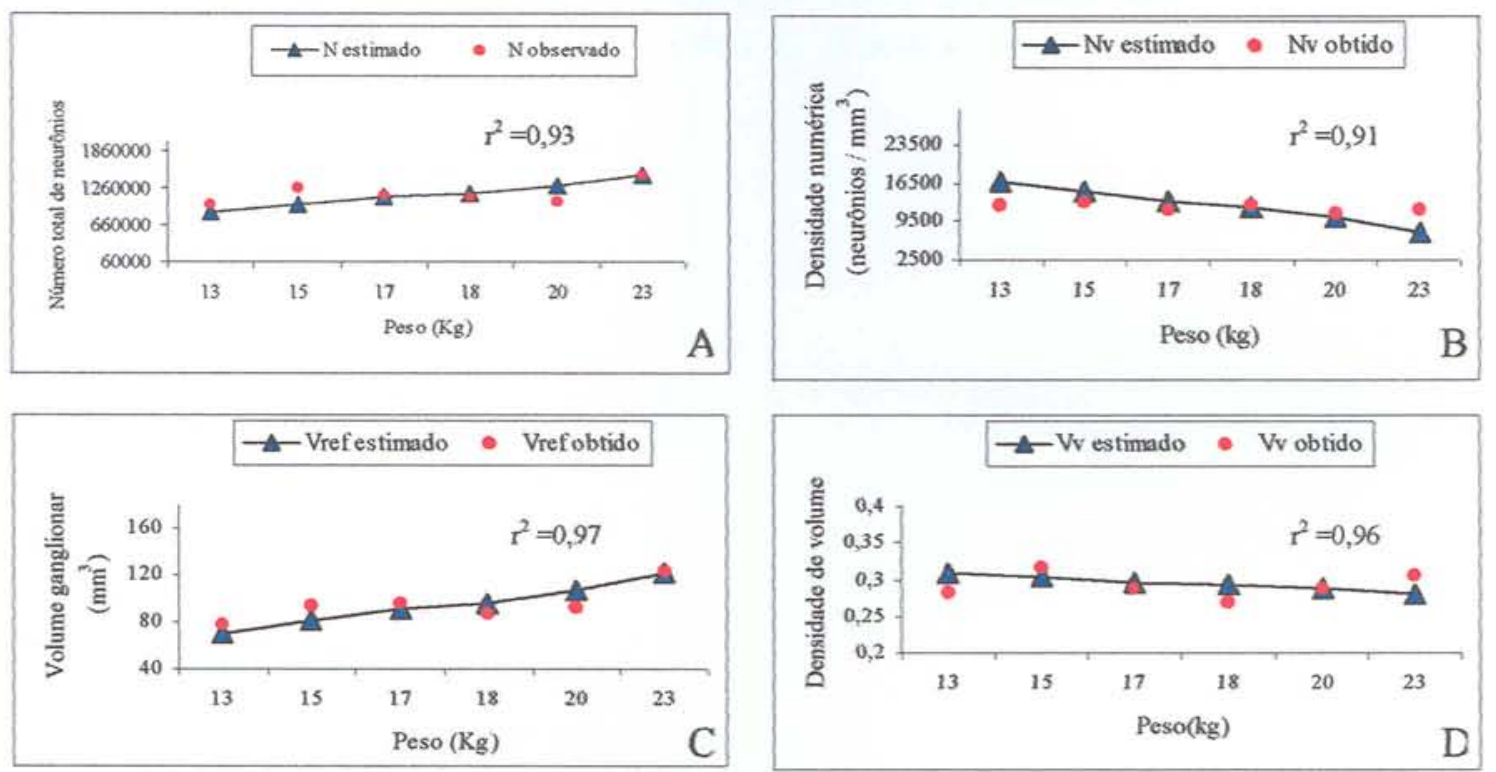

Figura 13 (A-D) - Gráficos demonstrando a relação entre as variáveis estereológicas e o peso corpóreo. A: número total de neurônios e peso corpóreo, B: densidade numérica e peso corpóreo, C: volume ganglionar e peso corpóreo e D: densidade de volume e peso corpóreo

A equação obtida para a variável densidade de volume foi: $\mathbf{V v}=0,34811+(-0,00299$ x Kg). Esta função apresentou um coeficiente de determinação de 0,55 , tendo seu gráfico apresentado abaixo (Figura 14). 


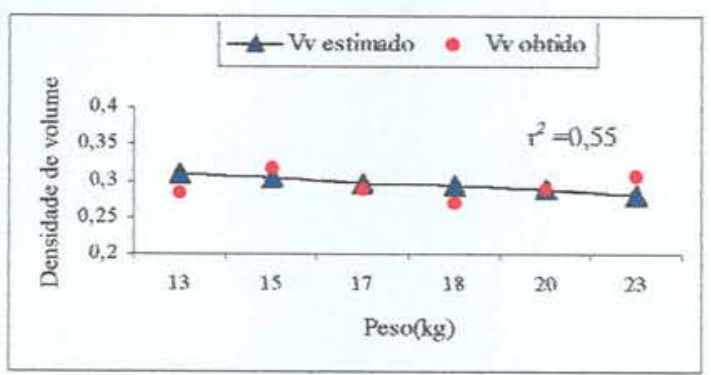

Figura 14 - Relação entre a densidade de volume e o peso corpóreo 


\section{DISCUSSÃO}

Este capítulo foi dividido em itens que referem se aos aspectos técnicos, aos aspectos morfológicos macro e microestruturais, aos aspectos macro e micromorfométricos e aos aspectos estereológicos.

\subsection{ASPECTOS TÉCNICOS}

Devido à necessidade da alta resolução e definição tanto para a quantificação quanto para o estudo morfométrico, foi extremamente importante utilizar fixador por meio de perfusão vascular (técnica de fixação mais eficiente no momento) e resina que não causassem problemas como a retração do material. Frente a esta questão, a utilização do fixador (solução de Karnovsky modificada) apropriado e a utilização de resina plástica do grupo Epoxi (Resina Araldite) para embeber o material foram requisitos primordiais desta pesquisa. A opção pela resina ao invés da parafina está associada a retração que esta causa, como também relatado por Guillery e Herrup (1997), Gardella et al. (2003) e Von Bartheld, (2002). Ainda, a utilização da parafina impossibilitaria a realização de cortes semi-finos necessários para as análises quantitativas e morfométricas.

A retração, não apenas a neuronal, mas de todo o gânglio tentou ser evitada para promover uma acurada estimativa do volume ganglionar. No entanto, embora todas as variáveis responsáveis pela retração tenham sido controladas limitadamente, para calcular o volume seguindo o método de Cavalieri, método de eleição desta pesquisa, se fez necessário seccionar o material, tendo conseqüentemente uma diminuição no seu tamanho. Por outro lado, a estimativa do volume através do método de Scherle não levou a uma diminuição no tamanho do gânglio. Contudo, a não utilização deste método nesta pesquisa relaciona-se a 
presença da artéria mesentérica caudal encontrada no interior do gânglio, que por si só superestima os resultados, pois de acordo com o método, o peso da estrutura estudada corresponderá ao volume da mesma. Além disto, o método de Scherle não é indicado para materiais previamente fixados e diminutos (HOWARD; REED, 1998), como é o caso do GMC.

A escolha do método estereológico disector físico para a quantificação dos neurônios no GMC de cães em diferentes faixas etárias, embora ser mais laborioso frente ao disector óptico (COGGESHALL, 1992; GARDELLA et al., 2003; GUNDERSEN et al., 1988; VON BARTHELD, 2002), fez-se primeiramente pelo fato da quantificação neuronal ser realizada através da contagem de corpos celulares (pericários) e não através do núcleo ou nucléolo, como freqüentemente ocorre no disector óptico. O problema em contar os corpos celulares no disector óptico está relacionado à dificuldade em identificá-los dentro de uma secção espessa (COGGESHALL, 1992), tendo ainda associado possiveis erros, como a sobreposição e "lost caps" (PAKKENBERG; GUNDERSEN, 1988).

Apesar de ser mais prático quantificar o número total de neurônios pela quantidade de núcleos ou nucléolos que aparecem entre o primeiro e o último plano focal de uma secção espessa (COGGESHALL; LEKAN, 1996; GUNDERSEN et al., 1988a) do que alinhar duas seções adjacentes (disector físico) a procura dos perfis dos corpos celulares, a utilização de tal manobra não poderia ser realizada no material utilizado nesta pesquisa, pelo fato de não poder assumir que os neurônios do GMC de cães são mononucleados ou mononucleolados, e de fato, os resultados desta pesquisa revelaram a existência de tais neurônios no grupo dos filhotes. Todavia, a utilização de contagem por meio do núcleo ou nucléolo não exclui a escolha do método disector físico, como visto no trabalho de Pakkenberg e Gundersen (1988) e Popken e Farel (1997), onde estes utilizaram o núcleo para quantificar o número total de neurônios. 
A afirmação acima relaciona-se ao fato dos neurônios encontrados nos gânglios prévertebrais dos mamíferos não serem em sua totalidade mononucleados como afirmado por Miolan e Niel (1996), pois Ermilov et al. (2000) e Szurszewski e Miller (1994) encontraram neurônios binucleados em guinea pigs, Ribeiro (2003) ${ }^{4}$ em capivaras e Sasahara et al. (2003) em coelhos. Ainda, é sabido que nas fases iniciais do desenvolvimento podem ser encontrados neurônios binucleados (APPENZELLER, 1990; SZURSZEWSKI; KING, 1988), tal fato sendo mais um precedente para a não escolha do núcleo como estrutura de contagem, pois na fase mais precoce estudada (cães com idade entre 1 a 2 meses) não foi possível determinar se toda a divisão celular já havia sido completada ou não. Da mesma forma, a utilização do nucléolo como estrutura de contagem não poderia ser utilizada, pois Castro (2001) relata a existência de mais de um ou dois nucléolos nos neurônios do gânglio cervical superior e Miller et al. (1996) e Ribeiro et al (2002) no gânglio celíaco mesentérico.

Pelo fato do método disector (físico ou óptico) limitar-se a contar não mais que 200 células, sendo por esta razão considerado simples e altamente eficiente (GUNDERSEN et al., 1988a; MAYHEW; GUNDERSEN, 1996) quando comparado com os demais métodos de quantificação (COGGESHALL; LEKAN, 1996), esta quantidade representa um pequeno percentual do número total de neurônios. Desta maneira, torna-se necessário uma amostragem ideal, principalmente quando a densidade numérica (neurônios $/ \mathrm{mm}^{3}$ ) for alta, como observado no grupo dos filhotes deste trabalho, onde a falta de uma amostragem sistemática levará a quantificação de apenas uma região, mesmo quando o material for considerado isotrópico (homogêneo). Por esta razão, a amostragem aleatória e sistemática do material é o principal ponto nos métodos estereológicos de quantificação e em qualquer tentativa de investigação qualitativa, pois assim, todas as partículas podem ser amostradas com uma probabilidade uniforme (BADDELEY, 2001; GUNDERSEN et al., 1988a; GUNDERSEN et al., 1999;

\footnotetext{
${ }^{4}$ Informação fornecida por Ribeiro em comunicação pessoal, em 2003.
} 
PAKKENBERG; GUNDERSEN, 1988). Uma amostragem não sistemática pode levar a uma variação nos resultados de até $50 \%$, como verificado por Popken e Farel (1997) na quantificação de neurônios do gânglio sensorial de ratos, devido a não distribuição homogênea destes neurônios neste gânglio (material anisotrópico).

\subsection{ASPECTOS MORFOLÓGICOS: MACRO E MICROESTRUTURAIS}

A localização do GMC em cães de diferentes faixas etárias concorda com os relatos de Evans (1993), Goshal (1986) e Gagliardo et al. (2003). Macroscopicamente o gânglio foi visto como uma única massa ganglionar nos cães em todos os grupos etários, da mesma forma que relatado por Gagliardo et al. (2003) em filhotes e adultos. No entanto, Goshal (1986) reporta que o GMC pode ser dividido em duas massas no cão e quatro no gato. Embora não tenha sido verificado mais de uma massa ganglionar macroscopicamente, foi verificado que nos filhotes o GMC apresenta de duas a quatro massas ganglionares (ou lobos ganglionares) quando vista microscopicamente, confirmando os achados de Goshal (1986).

O padrão morfológico do GMC de cães foi similar entre todos os grupos etários, isto é, o gânglio era dividido em compartimentos por meio de septos de tecido conjuntivo provenientes da cápsula, como também relatado por Banks (1992), Gabella, Trigg e McPhail, (1988), Gagliardo et al. (2003), Miolan e Niel, (1996), Schmidt (1996), Szurszewski e King (1988) e Szurszewski e Miller (1994) para os gânglios pré-vertebrais. Contudo, nos filhotes não foi observado apenas uma única massa ganglionar envolvida por uma cápsula, mas sim a existência de duas a quatro massas ganglionares unidas por um tecido conjuntivo frouxo e cada massa ganglionar sendo envolvida por uma cápsula. No entanto, com a maturação e envelhecimento estas massas fundem-se. Ainda, o aumento na quantidade de tecido não neuronal também relaciona-se como uma conseqüência 
do aumento da idade, fazendo com que os neurônios em um cão adulto ou senil estejam mais distantes do que em um filhote, expressos diretamente por meio de diferenças na densidade neuronal.

\subsection{ASPECTOS MACRO E MICROMORFOMÉTRICOS}

O tamanho do GMC, expresso através do seu maior eixo, aumentou em $83,5 \%$ do filhote para o adulto. Entretanto, da vida adulta para a senil foi verificado um aumento de apenas $2,4 \%$.

O tamanho dos neurônios no GMC de cães, nas diferentes faixas etárias, verificado através de sua área seccional, aumentou progressivamente e significativamente com o aumento da idade, tendo sido verificado um aumento de $2,25 \mathrm{x}$ do filhote para o adulto e de $1,2 \mathrm{x}$ do adulto para o senil. Semelhantes resultados foram reportados nos neurônios presentes nos gânglios celíaco mesentérico superior, cervical superior (BAKER; SANTER, 1988; BERGMAN; ULFHAKE, 1998; SCHMITH, 1996), nodoso (SOLTANPOUR, BAKER e SANTER, 1996) e hipogástrico (BERGMAN; ULFHAKE, 1998).

O aumento no tamanho do perfil neuronal entre os filhotes e adultos é explicado pela incompleta maturação dos neurônios no início das fases de desenvolvimento, como também relatado por Vega, Calzada e Del Valle (1993) e Masliukov (2001). No entanto, um aumento significativo no tamanho do perfil neuronal entre um animal adulto e um senil é passível de algumas especulações como: a possibilidade de um alargamento do corpo celular por um aumento no depósito de pigmentos como a lipofucsina (FINCH, 1993; WARBURTON; SANTER, 1997), ou um aumento do corpo celular pela diminuição da pressão exercida por células vizinhas devido à morte celular (BAKER; SANTER, 1988), ou um aumento para compensar a perda neuronal com o avanço da idade (FINCH, 1993; WARBURTON; SANTER, 1997). 
Da mesma forma que foi verificado um aumento no tamanho do corpo celular do neurônio com o aumento da idade, foi verificado um aumento no tamanho do núcleo. Porém, o aumento do núcleo foi significativo apenas quando comparado os filhotes com os demais grupos, onde foi encontrado um fator de aumento de $1,56 \mathrm{x}$ do filhotes para o adulto e de $1,62 x$ do filhote para o senil. Já do adulto para o senil a mudança no tamanho do núcleo não foi significativa, tendo um fator de aumento de apenas $1,04 \mathrm{x}$. O aumento do núcleo do filhote para o adulto está relacionado com a fase estudada, onde é sabido que nas fases de maturação neuronal é esperado um aumento no volume nuclear (McMAHON; DOCKERY; DERMOT, 2003), sendo este fato também reportado por Mayhew (1989) nos gânglios da raiz dorsal de ratos de 20 e 120 dias.

A relação núcleo-citoplasma nos neurônios do GMC diminuiu com o aumento da idade, da mesma forma dos achados de LEDDA et al. (2000). Para ocorrer uma diminuição nesta relação é necessário que a área ocupada pelo citoplasma no filhote seja inferior a área ocupada no adulto e senil, ou que a área ocupada pelo núcleo no filhote seja superior a área ocupada no adulto e senil, ou uma associação das duas hipóteses. Neste trabalho, foi verificado que a área ocupada pelo núcleo aumenta, da mesma forma que aumentou a área ocupada pelo citoplasma. No entanto, embora ambos, núcleo e citoplasma, tenham aumentado, a proporção do aumento do citoplasma foi superior a do núcleo com a progressão da idade.

Relacionado a forma do perfil neuronal, como relatado anteriormente, esta não se relaciona ao tamanho do mesmo. No entanto, os eixos do perfil neuronal, isto é, os eixos maior e menor, com a progressão da idade, tendem a tornar mais simétricos, fazendo com que os neurônios deixem de ter uma forma elíptica e passando para uma forma mais ovalada. 


\subsection{ASPECTOS ESTEREOLOGICOS}

Os aspectos estereológicos foram divididos em: volume do espaço referência (ou ganglionar), densidade numérica, número total de neurônios e relação entre as variáveis estereológicas e o peso corpóreo.

\subsubsection{VOLUME DO ESPAÇO REFERÊNCIA OU GANGLIONAR (Vref)}

O volume do GMC de cães aumenta com a progressão da idade, sendo encontrado um aumento de $37,9 x$ do filhote para o adulto e de $45,4 x$ do filhote para o senil, apresentando este uma correlação positiva com o aumento do peso corpóreo do animal. Semelhantes resultados foram verificados por Soltanpour, Baker e Santer (1996) no gânglio nodoso de ratos, Popken e Farel (1997) no gânglio da raiz dorsal de ratos, Warburton e Santer (1997) no gânglio hipogástrico e Bergman e Ulfhake (1998) no gânglio cervical (C5) e lombar (L4) da raiz dorsal.

\subsubsection{DENSIDADE NUMÉRICA OU DENSIDADE NEURONAL (Nv)}

A densidade numérica (neurônios $/ \mathrm{mm}^{3}$ ) no GMC verificada nos filhotes foi superior aos demais grupos (adulto e senil), representando os adultos apenas $42 \%$ e os senis $38,5 \%$ da $\mathrm{Nv}$ encontrada nos filhotes. Similar aos nossos resultados, Popken e Farel (1997) relataram uma redução de $50 \%$ na densidade neuronal nos gânglios da raiz dorsal entre ratos de dois a três meses quando comparados com os de 30 meses e Warburton e Santer (1997) uma diminuição 
de $40 \%$ no gânglio hipogástrico quando comparados ratos de quatro meses com os de 24 meses.

A alta densidade numérica no GMC dos filhotes está relacionada ao pequeno volume médio neuronal, enquanto que nos animais adultos e senis a densidade tende a diminuir, sendo explicado em virtude do aumento do volume neuronal e ao aumento na quantidade de tecido não-neuronal (tecido conjuntivos, vasos e neuropilo), verificado pela diminuição de $17 \%$ na proporção volumétrica ocupada pelos neurônios no GMC quando comparado um filhotes com um adulto e senil.

\subsubsection{NÚMERO TOTAL DE NEURÔNIOS}

Ainda que seja fácil de se pensar que o aumento da idade associa-se a uma diminuição no número totais de neurônios pelo simples fato destas células serem consideradas pósmitóticas, isto é, de não possuírem a capacidade de se dividir (ALBERTS et al., 1994; KLEINMAN; BERNFIELD, 1997), mesmo que haja algumas controvérsias atuais sobre este dogma (CRUTCHER, 2002), e por ser a apoptose ser um processo natural do desenvolvimento (ALBERTS et al., 1994; KLEINMAN; BERNFIELD, 1997; RUTTEN et al., 2003), este fato não é considerado verdade absoluta (FINCH, 1993). Tal afirmação também foi verificada com os resultados obtidos nesta pesquisa, onde os cães senis não apresentaram diferenças significativas em relação ao número total de neurônios dos cães adultos e nem se quer perda. Ainda nestes dois grupos uma quantidade significativamente maior de neurônios foi estimada em relação aos filhotes.

No entanto, é importante ressaltar que o método utilizado nesta pesquisa forneceu uma estimativa indireta do número total de neurônios, sendo esta influenciada pelas variáveis densidade numérica e principalmente pelo volume ganglionar (ou do espaço referência). De 
acordo com Mayhew (1991) a obtenção da densidade numérica (neurônios $/ \mathrm{mm}^{3}$ ), utilizando o método do disector fornece resultados fiéis, sendo estes mais acurados do que o número total de neurônios. O problema da estimativa do número total de neurônios utilizando o método do disector está vinculado ao volume ganglionar, pois os gânglios autonômicos não são formados apenas por neurônios. Outros elementos celulares como células da glia, SIF cells, mastócitos, fibroblastos são encontrados nos gânglios (GABELLA, 1995; GAGLIARDO et al., 2003; MIOLAN; NIEL, 1996; SZURSZEWSKI; KING, 1988; SZURSZEWSKI; MILLER, 1994), podendo estes elementos estar em maior quantidade ou terem seu volume aumentado com a progressão da idade. Ainda, além dos elementos celulares, o gânglio também é composto por cápsula, tecido conjuntivo e ainda por vasos (BANKS, 1992; GABELLA; TRIGG; MCPHAIL, 1988; GAGLIARDO et al., 2003; MIOLAN; NIEL, 1996; SCHMIDT, 1996; SZURSZEWSKI; KING, 1988; SZURSZEWSKI; MILLER, 1994), que também podem estar alterados durante o desenvolvimento.

A quantidade total de neurônios no GMC de cães nos filhotes representou apenas $6,3 \%$ da encontrada nos adultos e 5,8\% da encontrada nos animais senis. A pequena porcentagem de neurônios obtida nos filhotes em relação aos demais grupos (adultos e senis) poderia estar associada ao pequeno volume ganglionar dos filhotes quando comparado aos demais grupos ou a uma possível divisão celular encontrada em fases do desenvolvimento subseqüente ao período de análise dos neurônios ganglionares dos filhotes, embora este último dado não foi investigado. Tal fato pode ser verificado pela presença de células binucleadas no interior do gânglio dos filhotes, mesmo que em pequena quantidade (3\%). No entanto, Farel (2003) relata que o aumento no número de neurônios no gânglio da raiz dorsal de ratos não está relacionado a uma possível neurogênese, e sim a uma diferenciação tardia destes, onde muitas vezes estes neurônios não são quantificados por não apresentarem uma forma típica. 
Embora não tenha sido verificado a neurogênese no gânglio da raiz dorsal de ratos, não se pode afirmar que não ocorra no CMC de cães. Por outro lado, a existência de células binucleadas pode ser uma característica comum desta espécie, como verificado em alguns roedores como guinea pig (ERMILOV et al., 2000; SZURSZEWSKI; MILLER, 1994) e capivaras (RIBEIRO, 2003) $)^{5}$ e também em coelhos (SASAHARA et al., 2003). Entretanto nenhum relato da presença de células binucleadas no GMC de cães foi feito anteriormente.

Em concordância com os resultados encontrados no GMC de cães, Warburton e Santer (1997), utilizando o mesmo método no gânglio hipogástrico de ratos, relataram um número maior de neurônios nos animais mais velhos (24 meses) do que os mais novos (4 meses). Da mesma forma, Popken e Farel (1997) encontraram resultados semelhantes nos neurônios dos gânglios da raiz dorsal (L3-L6) de ratos de 11 dias quando comparado aos de 80 dias. Santer (1991) também obteve semelhantes resultados no gânglio cervical superior de ratos de quatro e 24 meses, mas utilizando o método fracionador.

Diferentemente dos autores anteriormente citados, Bergman e Ulfhake (1998) utilizando o método do disector óptico relataram que o número de neurônios nos gânglios sensitivos da raiz dorsal (C5 e L4) de ratos de dois a três meses é maior nesses animais quando comparados com ratos de 30 meses, diferente de Popken e Farel (1997) que também trabalharam com gânglios da raiz dorsal.

\subsubsection{RELAÇÃo ENTRE AS VARIÁVEIS ESTEREOLÓGICAS E O PESO CORPóREO}

Utilizando-se da análise de regressão linear foi possível predizer a relação de todas as variáveis estereológicas em função do peso corpóreo. Um estudo semelhante foi realizado por

\footnotetext{
${ }^{5}$ Informação fornecida por Ribeiro em comunicação pessoal, em 2003.
} 
Mayhew (1991) em diferentes espécies, contudo utilizando a análise de regressão logarítmica e correlacionando o peso do cerebelo ao número de células de Purkinje. Embora foi possível estabelecer uma correlação entre peso e o número total de neurônios no GMC de cães, está claro que os resultados obtidos por Mayhew (1991) estão sujeitos a uma porcentagem de erros menor em relação aos resultados deste trabalho, pelo fato do trabalho correlacionar o peso do órgão (cerebelo) e não do animal como um todo.

Fazendo se o uso das funções lineares obtidas neste trabalho, foi possível predizer que cães de $180 \mathrm{~g}, 15 \mathrm{Kg}$ e $23 \mathrm{Kg}$ apresentam, respectivamente, $106.041,5 ; 982.111$ e 1.455 .023 neurônios, 28.946; 15.082,87 e 7.599,07 neurônios $/ \mathrm{mm}^{3}$, um volume de 4,27; 81,07e 122,52 $\mathrm{mm}^{3}$, a densidade de volume de $34 \% ; 30,32 \%$ e $27,9 \%$ e um volume neuronal médio de $12.126,1 ; 22.261,8$ e $27.733,2 \mu \mathrm{m}^{3}$. Os nossos resultados para estes mesmos cães foram de $81.677,42 ; 1.243 .421$ e $1.452 .534,09$ de neurônios, $32.258,06 ; 13.157,8$ e $11.704,55$ neurônios $/ \mathrm{mm}^{3}$, um volume de 2,53; 94,5 e $124 \mathrm{~mm}^{3}$, uma proporção volumétrica de $39,01 \%$; $31,82 \%$ e $28,94 \%$ e um volume médio neuronal de $12.093,1 ; 24.183,4$ e $26.261,0 \mu^{3}$. Embora estes valores em algumas variáveis apresentem distantes, a confiabilidade da função, expressa através do coeficiente de determinação $\left(\mathrm{r}^{2}\right)$, foi alta para estas variáveis, com exceção da variável densidade de volume, onde apenas $55 \%$ dos resultados coincidem com os resultados adquiridos nesta investigação cientifica.

As correlações existentes entre as variáveis estereológicas e o peso podem ser facilmente visualizadas no exemplo acima, onde: o aumento no peso corpóreo do animal é acompanhado por um aumento no volume ganglionar e conseqüentemente por um aumento no número total de neurônios. Por outro lado, o aumento no volume ganglionar é acompanhado por uma diminuição na quantidade de neurônios por $\mathrm{mm}^{3}$ (densidade numérica) e conseqüentemente por uma diminuição na densidade de volume dos neurônios dentro do gânglio. Ainda, o aumento no volume médio do neurônio está relacionado a um aumento no 
peso corpóreo. Desta forma, numa visão geral e integrada, é possível observar que em um animal de $180 \mathrm{~g}$ o volume do gânglio é inferior quando comparado com um animal de $15 \mathrm{Kg}$ e de $23 \mathrm{Kg}$, da mesma forma que a quantidade de neurônios é inferior nesta mesma relação. Entretanto, a densidade numérica no animal de $180 \mathrm{~g}$ é superior a do animal de $15 \mathrm{Kg}$ e de $23 \mathrm{Kg}$, da mesma forma que a densidade de volume é superior. Contudo, o volume neuronal médio de um animal maior é superior ao de um animal mais leve. 
CONCLUSÃO 


\section{CONCLUSÃo}

Após a análise dos resultados e de acordo com os métodos empregados, pode-se concluir que:

$\checkmark$ Microscopicamente o gânglio mesentérico caudal (GMC) é constituído por mais de uma massa ganglionar nos filhotes. Porém, com a maturação e envelhecimento estas se fundem formando uma massa ganglionar única.

$\checkmark$ Estruturalmente, uma das características observadas durante o envelhecimento é a marcada e progressiva deposição de lipofucsina no interior dos neurônios do GMC.

$\checkmark \mathrm{O}$ aumento da idade é verificado por um aumento progressivo e significativo do tamanho do neurônio no GMC de cães. Com relação ao núcleo, este aumenta significativamente apenas da fase inicial da maturação para a vida adulta.

$\checkmark$ A relação núcleo-citoplasma diminui com a progressão da idade no GMC de cães.

$\checkmark$ Quantitativamente, durante o envelhecimento observa-se que o número total de neurônios no GMC aumenta com a idade em cães adultos e senis. Opostamente, a densidade neuronal diminui progressivamente com a maturação e envelhecimento.

$\checkmark$ O volume ganglionar aumenta progressivamente com o aumento da idade. Da mesma forma, ocorre um aumento do tecido não neuronal (representado pelo neuropilo, vasos e tecido conjuntivo).

$\checkmark$ A correlação entre as variáveis estereológicas $(N, N v$, Vref, $V v$ e $V n$ ) e o peso corpóreo apresentaram um alto coeficiente de correlação, desta forma sendo possível aplicar a análise de regressão linear em função do peso corpóreo. Portanto, foi possível 
desenvolver uma função onde pode-se predizer o comportamento das variáveis estereológicas em função do peso, tendo os resultados obtidos através desta muito próximos aos dados reais, verificado pelo alto coeficiente de determinação obtido. 
REFERÊNCIAS 


\section{REFERÊNCIAS}

ABERCROMBIE, M. Estimation of nuclear population from microtome sections. Anatomical Record, v. 94, p. 239-247, 1946.

ALBERTS, B.; BRAY, D.; LEWIS, J. RAFF, M.; ROBERTS, K.; WATSON, J. D. Biologia molecular da célula. Porto Alegre: Artmed, 1997. 1249p.

ANDREWS, T. J. Autonomic nervous system as a model of neuronal aging: the role of target tissue and neurotrophic factors. Microscopy Research and Techniques, v. 35, p. 2-19, 1996.

ANDREWS, T. J; THRASIVOULOU, C.; NESBIT, W.; COWEN, T. Target-specific differences in the dendritic morphology and neuropeptide content of neurons in the rat SCG during development and aging. The Journal of Comparative Neurology, v. 368, p. 33-44, 1996.

APPENZELLER, O. Anatomy and histology. In: Elsevier, 1990. p. 1-10.

The autonomic nervous system. Oxford:

BADDELEY, A. Is stereology "unbiased"? Trends in neuroscience, v. 24 , n. 7, p. 375-376, 2001.

BAKER, D. M.; SANTER, R. M. Morphometric studies on pre- and paravertebral sympathetic neurons in the rat: changes with the age. Mechanism of Ageing and Development, v. 42, 139-145, 1988.

BAKER, D. M.; SANTER, R. M.; BLAGGAN, A. S. Morphometric studies on the microvasculature of pré- and paravertebral sympathetic ganglia in the adult and aged rat by light and electron microscopy. Journal of Neurocytology, v. 18, p. 647-660, 1989.

BANKS, W. J. Sistema nervoso. In: . Histologia veterinária aplicada. São Paulo: Editora Manole, 1992. p. 318-351.

BENNETT, M. R.; GIBSON, W. G.; LEMON, G. Neuronal cell death, nerve growth factor and neurotrophic models: 50 years on. Autonomic Neuroscience. Basic and Clinical, v. 95, p. 1-23, 2002.

BERGMAN, E.; ULFHAKE, B. Loss of primary sensory neurons in the very old rat: neuron number estimates using the dissector method and confocal optical sectioning. The Journal of Comparative Neurology, v. 396, p. 211-222, 1998.

BHAMBURKAR, V. R.; PRAKASH, P. Quantitative histomorphological studies on the sympathetic ganglia of goat (Capra Hircus). Indian Veterinary Journal, v. 70, p. 337-340, 1993.

BILLUPS, K.L.; TILLMAN, S.; CHANG, T.S.K. Ablation of the inferior mesenteric plexus in the rat: alteration of sperm storage in the epididymis and vas deferens. Journal of Urology, v. 143, p. $625-629,1990$ a. 
BILLUPS, K.L.; TILLMAN, S. L.; CHANG, T.S.K. Reduction of epididymal sperm motility after ablation of the inferior mesenteric plexus in the rat. Fertility and Esterility, v. 53, p. 1076-1082, $1990 \mathrm{~b}$.

BOOWNE, M. A.; HOWARD, C. V.; JOLLEYS, G. D. Principles of stereological . In: WOOTON, R.; SRINGALL, D.R.; POLAK, J.M. Image analysis in histology: conventional and confocal microscopy. London: Cambridge University Press, 1995. p. 96-120.

BRODAL, A. O sistema nervoso autônomo:- O hipotalamo. In: com correlações clínicas. São Paulo: Roca, 1984. p. 563-585.

Anatomia neurológica

BURKITT, H.; YOUNG, B.; HEATH, J. Tecido Nervoso. In: funcional. Rio de Janeiro: Editora Guanabara Koogan, 1994. p. 112-138.

BYWATER, R. A. R. Activity following colonic distension in enteric sensory fibres projecting to the inferior mesenteric ganglion in the guinea-pig. Journal of the Autonomic Nervous System. v. 46, p. 19-26, 1993.

CASTRO, M. F. S. Estrutura e Ultraestrutura do complexo ganglionar cervical cranial em gatos (Felis catus - LINNAEUS, 1758) $136 \mathrm{f}$. Tese (Mestrado em Anatomia dos Animais Domésticos) Faculdade de Medicina Veterinária e Zootecnia, Universidade de São Paulo, São Paulo, 2001.

CHI-HSIEN, C., SHIH-HSIUNG, L.; CHING-LIANG, S. The ovarian innervation in the dog: a preliminary study for the base for electro-acupuncture. Journal of the Autonomic Nervous System, v. 35 , p. $185-192,1991$.

COGGESHALL, R. E. A consideration of neural counting methods. Techniques, v. 15, n. 1, p. 9-13, 1992.

COGGESHALL, R. E.; LEKAN, H. A. Methods for determining numbers of cells and synapses: a case for more uniform standards of review. The Journal of Comparative Neurology, v. 364, p. 6-15, 1996.

CORMACK, D. H. The autonomic nervous system. In: Philadelphia: J. B. Lippincott, 1987. p. 381-385. . Ham's histology. 9. ed.

COWEN, T. Selective vulnerabilityin adult and ageing mammalian neurons. Autonomic Neuroscience. Basic and Clinical, v. 96, p. 20-24, 2002.

CRUTCHER, K. A. Aging and neuronal plasticity: lessons from a model. Autonomic Neuroscience. Basic and Clinical, v. 96, p. 25-32, 2002.

CRUZ-ORIVE, L. M. Systematic sampling in stereology. Bull. Intern. Statis., v. 52, p. 451$468,1993$.

DÂNGELO, J.G.; FATTINI, C.A. Sistema nervoso autônomo: aspectos gerais. In: Anatomia humana básica, 1987. p. 72-87.

DI DIO, L. J. A., NITRINI, R. Sistema nervoso. In: DI DIO, L. J. A. Tratado de anatomia sistêmica aplicada. São Paulo: Atheneu, 2002. v. 2, p. 703-870. 
DUERSTOCK, B. S.; BAJAJ, C. L.; BORGENS, R. B. A comparative study of the quantitative accuracy of tree-dimensional reconstructions of spinal cord from serial histological sections. Journal of Microscopy, v. 210, n. 2, p. 138-148, 2003.

DYCE, K. M.; SACK, W. O; WENSING, C. J. G. The nervous system. In: Textbook of veterinary anatomy. 2. ed. London: W. B. Saunders, 1997. p. 259-324.

ELFVIN, L. G.; LINDH, B.; HÖKFELT. T. The chemical neuroanatomy of sympathetic ganglia. Annu. Ver. Neurosci., v. 16, p. 471-507, 1993.

EL-SALHY, M; SANDSTRÖM, O; HOLMLUND, F. Age-induced changes in the enteric nervous system in the mouse. Mechanisms of Ageing and Development, v. 107, p. 93-103, 1999.

ERMILOV, L. G.; MILLER, S. M.; SCHMALZ, P. F.; HANANI, M.; SZURSZEWSKI, J. H. The three-dimensional structure of neurons in the guinea pig inferior mesenteric and pelvic hypogastric ganglia. Autonomic Neuroscince, v. 83, p. 116-126, 2000.

EVANS, H. E. The autonomic nervous system. In: Miller's anatomy of the dog. London : W.B. Saunders, 1993. p. 776-799.

FAREL, P. B. Late differentiation contributes to the apparent increase in sensory neuron number in juvenile rat. Developmental Brain Research, v. 144, p. 91-98, 2003.

FINCH, C. E. Neuron atrophy during aging. programmed or sporadic? Trends in neurosciences, v. 6, n. 3, p. $104-110,1993$.

FUKUDA, H.; FUKAI, K; OKADA, H. Reflex responses of neurons in the inferior mesenteric ganglion to mechanical stimulation of the colon, rectum, anal canal, and urinary bladder in the dog. Japanese Journal of Physiology, v. 37, p. 223-241, 1987.

GABELLA, G. Autonomic nervous system. In: The rat nervous system. 2. ed. London: Academic Press, 1995. p. 81-103.

GABELLA, G. Fall in the number of myenteric neurons in aging guinea pigs. Gastroenterology, v. 96, p. 1487-1493, 1989.

GABELLA, G.; BERGGREN, T.; UVELIUS, B. Hypertrophy and reversal of hypertrophy in rat pelvic ganglion neurons. Journal of Neurocytology, v. 21, p. 649-662, 1992.

GABELLA, G.; TRIGG, P.; MCPHAIL, H. Quantitative cytology neurons and satellite glial cells in the superior cervical ganglion of the sheep-Relationship with ganglion neuron size. Neurocytology, v. 17, p. 753-769, 1988.

GAGLIARDO, K. M.; SILVA, R. A.; GUIDI, W. L.; RIBEIRO, A. A. C. M. Gross and semi-thin view of the caudal mesenteric complex of the domestic dog (Canis familiaris - Linnaeus, 1758). Anatomia Histologia Embryologia, v. 32, p. 1-8, 2003.

GARDELLA, D.; HATTON, W. J.; RIND, H. B.; ROSEN, G. D.; Von BARTHELD, C. S. Differential tissue shrinkage and compression in the z-axis: implications for optical dissector counting in vibratome-, plastic- and cryosections. Journal of Neuroscience Methods, v. 124, p. 45-59, 2003. 
GAVAZZI, I.; COWEN, T. Can the neurotrophic hypothesis explain degeneration and loss of plasticity in mature and ageing autonomic nerves? Journal of the Autonomic Nervous System, v. 58, p. 1-10, 1996.

GEBOES, K; BOSSAERT, H. Gastrointestinal disorders in old age. Age Aging, v. 6, p. 197-200, 1977.

GONELLA, J.; BOUVIER, M.; BLANQUET, F. Extrinsic nervous control of the motility of small and large intestines and related spincters. Physiological Reviews, v. 67, n. 3, p. $902-$ 961, 1987.

GOSHAL, N. G. Inervação abdominal, pélvica e caudal autônoma. In: GETTY, R. Anatomia dos animais domésticos. 5. ed. Rio de Janeiro: Guanabara Koogan, 1986. v. 2, p. 1628-1634.

GUILLERY, R. W.; HERRUP, K. Quantification without pontification: choosing a method for counting objects in sectioned tissues. The Journal of Comparative Neurology, v. 386, p. 2-7, 1997.

GUNDERSEN, H. J. G.; BAGGER, P.; BENDTSEN, T. F.; EVANS, S. M.; KORBO, L.; MARCUSSEN, N.; MOLLER, A.; NIELSEN, K; NYENGAARD, J. R.; PAKKENBERG, B.; SORENSEN, F. B.; VESTERBY, A.; WEST, M. J. The new stereological tools: dissector, fractionator, nucleator and point sampled intercepts and their use in pathological research and diagnosis. Acta Pathologica Microbiologica et Immunologica Scandinavica, v. 96, p. 857$881,1988 \mathrm{a}$.

GUNDERSEN, H. J. G.; BENDTSEN, T. F.; KORBO, L.; MARCUSSEN, N.; NIELSEN, K.; NYENGAARD, J. R.; PAKKENBERG, B.; SORENSEN, F. B.; VESTERBY, A.; WEST, M. J. Some new, simple and efficient stereological methods and their use in pathological research and diagnosis. Acta Pathologica Microbiologica et Immunologica Scandinavica, v. 96, p. 379-394, 1988b.

GUNDERSEN, H. J. G.; JENSEN, E. B; KIÊU, K; NIELSEN, J. The efficiency of systematic sampling in stereology - reconsidered. Journal of Microscopy, v. 193, n. 3, p. 199-211, 1999.

GUNDERSEN, H. J. G.; JENSEN, E.B. The efficiency of systematic sampling in stereology and its prediction. Journal of Microscopy, v. 147, p. 229-263, 1987.

GUNDERSEN, H. J. G. Notes on the estimation of the numerical density of arbitrary profiles: edge effect. Journal of microscopy, v. 111, p. 219-223, 1977.

HASSER, E. M.; SCHADT, J. C. Autonomic Phisiology. Seminars in Veterinary and Surgery. Small Animal, v. 5, n. 1, p. 12-16, 1990.

HENERY, C. C.; MAYHEW, T. M. The cerebrum and cerebellum of the fixed humans brain: efficient and unbiased estimates of volumes and cortical surface areas. Journal of Anatomy, v. 167, p. $167-180,1989$.

HOWARD, C.V.; REED, M.G. Three-dimensional measurement in microscopy. In: Unbiased stereology. Oxford: Bios Scientif Publishers, 1998. 246 p. 
HOWARD, V.; REID, S.; BADDELEY, A.; BOYDE, A. Unbiased estimation of particles density in the tandem scanning reflected light microscope. Journal of Microscopy, v. 138, n. 2, p. 203-212, 1985.

IRIE, M; KAJYYAMA, Y.; ENJOJ, A.; OZEKI, K; URA, K.; KANEMATSU, T.Changes in colomic motility in dogs after a resection of the inferior mesenteric ganglion and plexus. Surgery Today Tokyo, v. 28, p. 626-623, 1998.

JOBLING, P.; GIBBINS, I L. Eletrophysiological and morphological diversity of mouse sympathetic neurons. Journal Neurophysiology, v. 82, p. 2747-2764, 1999.

JUNQUEIRA, L. C.; CARNEIRO, J. Tecido nervoso. In: . Histologia básica. Rio de Janeiro: Guanabara Koogan, 1995. p. 127-158.

KALECZYC, J.; TIMMERMANS, J. P; MAJEWSKI, M; LAKOMY, M.; SCHEUERMANN, D. W. Distribution and immunohistochemical characteristics of neurons in the porcine caudal mesenteric ganglion projecting to the vas deferens and seminal vesicle. Cell and Tissue Research, v. 282, p. 5968, 1995.

KIHARA, K; SATO. K.; ISHIZAKA, K; OSHIMA, H. Preservation of ejaculatory function by reconstruction of the canine hypogastric nerve. Journal Neurosurgery, v. 88, p. 726-733, 1998.

KIHARA, K; SATO, K; OSHIMA, H. Sympathetic efferent pathways projecting to the vas deferens. Microscopy Research Technique, v. 42, p. 398-408, 1998.

KLEINMAN, H. K; BERNFIELD, M. Regulation of development: differentiation and morphogenesis. In: HOFFMAN, J. F.; JAMIESON, J. D. Handbook of physiology: cell physiology. Oxford: American Physiological Socity, 1997. p. 843-857.

KOBAYASHI, T.; KIHARA, K.; KAGEYAMA, Y.; YAMADA, T.; LIU, S.; SATO, K. Spontaneous reconstruction of the canine hypogastric nerve over a long period after removing half of its length. Autonomic Neuroscience. Basic and Clinical, v. 86, p. 151-162, 2001.

KONINGSMARK, B. W. Methods for the counting of neurons. In: NAUTA, W. J. H; EBESSON, S. O. E. Methods in neuroanatomy, New York: Springer-Verlag, 1970. p. 315-80.

LANGMAN, J. Sistema Nervoso Central. In. 1985. p. 306-339. Embriologia médica. São Paulo: Atheneu,

LARSEN, W. J. Development of the peripheral nervous system. In: London: Churchill Livingstone, 1997. p. 107-125. Human embriology.

LEDDA, M.; BARNI, L.; ALTIERI, L.; PANNESE, E. Decrease in the nucleo-cytoplasmic volume ratio of rabbit spinal ganglion neurons with age. Neuroscience Letters, v. 286, p. $171-174,2000$.

LUCKENSMEYER, G. B.; KEAST, J. R. Distribution and morphological characterization of viscerofugal projections from the large intestine to the inferior mesenteric and pelvic ganglia of the male rat. Neuroscience, v. 66, p. 663-671, 1995. 
LUCKENSMEYER, G. B.; KEAST, J. R. Immunohistochemical characterisation of viscerofugal neurons projecting to the inferior mesenteric and major pelvic ganglia in the male rat. Journal Autonomic Nervous System, v. 61, p. 6-16, 1996.

MACHADO, A. Sistema nervoso autônomo: aspectos gerais. In. São Paulo: Atheneu:, 2002. p. 129-137. Neuroanatomia funcional.

MASLIUKOV, M. P. Sympathetic neurons of the cat stellate ganglion in postnatal ontogenesis: morphometric analysis. Autonomic Neuroscience, v. 89, p. 48-53, 2001.

MASLIUKOV, M. P.; PANKOV, V. A.; STRELKOV, A. A.; MASLIUKOVA, E. A.; SHILKIN, V. V.; NOZDRACHEV, A. D. Morphological features of neurons innervating different viscera in the cat stellate ganglionm in postnatal ontogenesis. Autonomic Neuroscience, v. 84, p. 169-175, 2000.

MAYHEW, T. M. A review of recent advances in stereology for quantifying neural structure. Journal of Neurocytology, v. 21, p. 313-328, 1992.

MAYHEW, T. M. Accurate prediction of purking cell number from cerebellar weight can be achieved with the fracionator. The Journal of Comparative Neurology, v. 308, p. 162-168, 1991.

MAYHEW, T. M. MWAMENGELE, G. L. M.; DANTZER, V. Comparative morphometry of the mammalian brain: estimates of cerebral volumes and cortical surface areas obtained from macroscopic slices. Journal of Anatomy, v. 172, p. 191-200, 1990.

MAYHEW, T. M. Stereological studies on rat spinal neurons during postnatal development: estimates of mean perikaryal and nuclear volumes free from assumptions about shape. Journal of Anatomy, v. 162, p. 97-109, 1989.

MAYHEW, T. M.; GUNDERSEN, H. J. G. "If you assume, you can make an ass out of u and me": a decade of the dissector for stereological counting of particles in 3D space. Journal of Anatomy, v. 188, p. 1-15, 1996.

MAYHEW, T. M.; OLSEN, D. R. Magnetic resonance imaging (MRI) and model-free estimates of brain volume determined using the cavalieri principle. Journal of Anatomy, $v$. 178 , p. 133-144, 1991.

MCDOUGLAS, J. N.; MILLER, M. S.; BURKS, T. F.; KREULEN, D. L. Age-related changes in colonic function in rats. American Journal of Physiology, v. 247, p. 542-546, 1984.

MCMAHON, S. S.; DOCKERY, P.; MCDERMOTT, K.W. Estimation of nuclear volume as an indicator of maturation of glial precursor cells in the developing rat spinal cord: a stereological approach. Journal of Anatomy., v. 203, p. 339-344, 2003.

MILLER, S. M; HANANI, M; KUNTZ, S. M; SCHMALZ, P. F.; SZURSZEWSKI, J. H. Light, electron and confocal microscopic study of the mouse superior mesenteric ganglion. The Journal of Comparative Neurology, v. 365, p. 427-444, 1996.

MING-ZI-LI, MASUKO, S. Neuronal circuitry between the inferior mesenteric ganglion and lower intestine of dog. Archives of Histology and Cytology, v. 60, p. 391-404, 1997. 
MIOLAN, J.; NIEL, J. The mammalian sympathetic prevertebral ganglia: integrative properties and role in the nervous control of digestive tract motility. Journal of Autonomic Nervous System, v. 58, p. $125-38,1996$.

MIZERES, N. J. The anatomy of the autonomic nervous system in the dog. The American Journal of Anatomy, v. 96, p. 285-317, 1955.

MORRISON, J. H.; HOF, P. R. Life and death of neurons in the aging brain. Science, v. 278, n. 17, p. $412-418,1997$.

MOUTON, P.R. Bias in Estimating number. In: Principles and practises of unbiased stereology. Baltimore: The Johns Hopkins University Press, 2001. p. 61-70.

NOZDRACHEV, A. D.; OTELLIN, V. A .; RIAKHOVSKAIA, L. V..; ADAMATSKII, A. I. Structure of the initial portion of sympathetic input in ganglia of the colon and bladder. Fiziol-ZhSSSR-Im-I-M-Sechenova, v. 74, p. 661-670, 1988.

PAKKENBERG, B.; BOESEN, J.; ALBECK, M; GJERRIS, F. Unbiased and efficient estimation of total ventricular volume of the brain obtained from CT-scans by a stereology method.

Neuroradiology, v. 31, p. 413-417, 1989.

PAKKENBERG, B.; GUNDERSEN, H. J. G. New stereological method for obtaining unbiased and efficient estimates of total nerve cell number in human brain areas. Acta Pathologica, Microbiologica, et Immunologica Scandinavica, v. 97, p. 677-681, 1989.

PAKKENBERG, B.; GUNDERSEN, H. J. G. Total number of neurons and glial cells in human brain nuclei estimated by disector and fractionator. Journal of microscopy, v.150, p. 1-20, 1988.

PANU, R.; BO MINELLI, L.; BOTTI, M.; GAZZA, F.; ACONE, F.; PALMIERI, G. Peripheral ganglia supplying the genital smooth musculature in the female pig: an experimental study. Journal of Anatomy, v. 1999, p. 317-322, 2001.

PEVZNER, L. Allometric nucleo-citoplasmic volume relations and rotation ellipsoid neuronal bodies of the cat nodosal and superior sympathetic ganglia. Brain Research, v. 201, p. 13$21,1980$.

PIDSUDKO, Z.; KALECZYC, J.; MAJEWSKI, M.; LAKOMY, M.; SCHEUERMANN, D. W.; TIMMERMANS, J. P. Differences in the distribution and chemical coding between neurons in the inferior mesenteric ganglion supplying the colon and rectum in the pig. Cell Tissue Research, v. 303, p. 147-158, 2001.

POPKEN, G. J.; FAREL, P. B. Sensory neuron number in the neonatal and adult rats estimated by means of the stereologic and profile-based methods. The Journal of Comparative Neurology, v. 386, p. 8-15, 1997.

POVER, C. M: COGGESHALL, R. E. Verification of the disector method for counting neurons, with comments on the empirical method. The Anatomical Record, v. 231, p. 573-578, 1991.

POWLEY, T. L. Central control of the autonomic Functions. The organization of the autonomic nervous system. In: ZIGMOND, M. J.; BLOOM, F. E.; LANDIS, S. C.; ROBERTS, J. L.; SQUIRE, L. R. Fundamental Neuroscience. London: Academic Press, 1999. p. 1027-1050. 
PURVES, D; RUBIN, E.; SNIDER, W. D.; LICHTMAN, J. Relation of animal size to convergence, divergence, and neuronal number in peripheral sympathetic pathways. The Journal of Neuroscience, v. 6, n. 1, p. $158-163,1986$.

RANSON, S.W. Sistema nervoso autonomo. In: Anatomia do sistema nervoso. Desenvolvimento e função. Rio de Janeiro: Livraria Atheneu, 1955. p. 135-150.

RIBEIRO, A. A. C. M.; ELIAS, C. F.; LIBERTI, E. A.; GUIDI, W. L.; DE SOUZA, R. R. Structure and ultrastructure of the celiac mesenteric ganglion complex in the domestic dog. Anatomia Histologia Embryologia, v. 31, p. 344-349, 2002.

ROBERTS, N.; CRUZ-ORIVE, L. M; REID, N. M. K; BRODIE, D. A.; BOURNE, M; EDWARDS, R. H. T. Unbiased estimation of human body composition by the Cavalieri method using magnetic ressonance imaging. Journal of Microscopy, v. 171, p. 236-253, 1993.

ROBERTS, N.; GARDEN, A. S.; CRUZ-ORIVE, L. M.; WHITEHOUSE, G. H.; EDWARDS R. H. T. Estimation of fetal volume by MRI and stereology. The British Journal of Radiology, v. 67, p. 1067-1077, 1994.

RUTTEN, B. P. F.; KORR, H.; STEINBUSCH, H. W. M.; SCHMITZ, C. the aging brain: less neurons could be better. Mechanisms of Ageing and Development, v. 124, p. 349-355, 2003.

SANTER, R. M. Sympathetic neurone numbers in ganglia of young and aged rats. Journal Autonomic Nervous System, v. 33, p. 221-222, 1991.

SANTER, R. M.; BAKER, D. M. Enteric system In: AMENTA, F. Aging of the autonomic nervous system. London: CRC Press, 1993. p. 214-221.

SAS. User's guide:Basic and Statistic. Cary, 1995. p. 1686.

SASAHARA, T. H. C.; SOUZA R. R.; MACHADO, M. R. F.; SILVA, R. A.; GUIDI, W. L.; RIBEIRO, A. A. C. M. Macro- and microstructural organization of the rabbit's celiacmesenteric ganglion complex (Oryctolagus cuniculus). Annals of Anatomy, v.185, p. 441$448,2003$.

SCHERLE, W. A simple method for volumetry of organs in quantitative stereology. Mikroskopie, v. 26, p. 57-63, 1970.

SCHMIDT, R. E. Age-related sympathetic ganglionic neuropathology: human pathology and animal models. Autonomic Neuroscience. Basic \& Clinical, v. 96, p. 63-72, 2002.

SCHMIDT, R. E. Neuropathology of human sympathetic autonomic ganglia. Microscopy Research and Technique, v. 35, p. 107-121, 1996.

SCHMIDT, R.E. Pathology of the sympathetic nervous system. In: The pathology of the aging nervous system. DUCKETT, S. Philadelphia: Lea and Febiger, 1991. p. 431-442.

SCHMIDT, R. E; DORSEY, D. A.; MCDANIEL, M. L.; CORBETT, J. A. Caractherization of NADPH diaphorase activity in rat sympathetic autonomic ganglia- effect of diabetes and aging. Brain Research, v. 617, p. 343-348,1993a. 
SCHMIDT, R. E; DORSEY, D. A.; ROTH, K. A. Imunohistochemical characterization of NPY and substance P containing nerve terminals in aged and diabetic human sympatheticganglia. Brain Research, v. 583, p. 320-326, 1992.

SCHMIDT, R. E; McATEE, S. J.; PLURAD, D. A.; PARVIN, C. A.; COGSWELL, B. E.; ROTH, K. A. Differential susceptibility of the prevertebral and paravertebral sympathetic ganglia to experimental injury. Brain Research, v. 460, p. 214-226, 1988.

SCHMIDT,R.E.; PLURAD,S.B.; MODERT, C.W. Neuroaxonal dystrophy in the autonomic ganglia of aged rats. Journal of Neuropathology and Experimental Neurology, v. 42, n. 4, p. 376-390, 1983.

SCHMIDT, R. E.; PLURAD, S. B; PARVIN, C. A.; ROTH, K. A. Effect of diabetes and aging on human sympathetic autonomic ganglia. Am. J. Pathol., v. 143, p. 143-153, 1993 b.

SCHWARZE, E.; SCHRÖDER, L Compendio de anatomia veterinária. Espana: Editorial Acribia Zaragoza, 1970. p. 108-117.

SMOLEN, A. J. Morphology of synapse in the autonomic nervous system. Journal of Electron Microscopy Techniques, v. 10, p. 187-204, 1988.

SOLTANPOUR, N.; BAKER, D. M.; SANTER, R. M. Neurons and microvessels of the nodose (vagal sensory) ganglion in young adult and aged rats: morphometric and enzyme histochemical studies. Tissues \& Cell, v. 28; p. 593-602, 1996.

SOLTANPOUR, N.; BAKER, D.M.; SANTER, R.M. Neurons and microvessels of the nodose (vagal sensory) ganglion in young adult and aged rats: morphometric and enzyme histochemical studies. Tissue \& Cell, v. 28, n. 5, p. 593-602, 1996.

STERIO, D. C. The unbiased estimation of number and sizes of arbitrary particles using dissector. Journal of Microscopy, v. 134, p. 127-136, 1984.

SWENSON, M. J.; REECE, W. O. Equilíbrio hídrico e excreção. In: Animais Domésticos. Rio de Janeiro: Guanabara Koogan, 1996. p. 521-548.

Dukes Fisisologia dos

SZURSZEWSKI, J. H.; KING, B. F. Physiology of prevertebral ganglia in mammals with special reference to inferior mesenteric ganglion. In: SCHULTZ, S.G.; WOOD, J. D; RAUNER, B. B. Handbook of gastrointestinal physiology. Bethesda: American Physiological Society, 1988. v. 1, section 6, p. 519-577.

SZURSZEWSKI, J. H.; MILLER, S. M.. Physiology of the prevertebral ganglia. In: JOHNSON, L. R. Physiology of the gastrointestinal tract. 2. ed. New York: Raven Press, 1994. v. 1, p. 795-878.

SZWEDA, P. A.; CAMOUSE, M.; LUNDBERG, K. C.; OBERLEY, T. D.; SZWEDA, L. I Aging, lipofuscin formation, and free radical-mediated inhibition of cellular proteolytic systems. Ageing Research Reviews, v. 2, p. 383-405, 2003.

VEGA, J. A.; CALZADA, B.; DEL VALLE, M. E. Age-related in the mammalian autonomic and sensory ganglia. In: AMENTA, F. Aging of the autonomic nervous system. London: CRC Press, 1993. p. 31-61. 
VON BARTHELD, C. S. Counting particles in tissue sections: choices of methods and importance of calibration to minize biases. Histology and Histopathology, v. 17, p. 639-648, 2002.

WARBURTON, A. L.; SANTER, R. Sympathetic and sensory innervation of the urinary tract in Young adult and aged rats: a semi-quantitative histochemical and immunohistochemical study. Histochemical Journal, v. 26, p. 127-133, 1994.

WARBURTON, A. L.; SANTER, R. M.. The hypogastric ant thirteenth thoracic ganglia of the rat: effects of age on the neurons and their extracellular environment. Journal of Anatomy, v. 190, p. 115-124, 1997.

WASOWICZ, K.; MAJEWSKI, M.; LAKOMY, M. Distribuition of neurons innervating the uterus of the pig. Journal of Autonomic Nervous System, v. 74, p. 13-22, 1998.

WEIBEL, E. R. Stereological methods: practical methods for biological morphometry. London: Academic Press, 1979.

WEST, M. J. Advances in the study of age-related neuron loss. Seminars in the Neuroscience, v. 6, p. $403-411,1994$.

WHEATER, P. R.; BURKITT, H. G.; DANIELS, V. G. Tecidos Nervosos. In:

Wheather histologia funcional 3. ed. Rio de Janeiro: Guanabara Koogan, 1994. p. 112-138.

WRIGHT, L. L.; CUNNINGHAM, T. J.; SMOLEN, A. J. Developmental neuron death in the rat superior cervical sympathetic ganglion: cell counts and ultrastructure. Journal of Neurocytology, v. 12, p. 727-739, 1983. 